Susan Travis

\title{
CONSTRUÇÕES FAMILIARES: UM ESTUDO SOBRE A CLÍNICA DO RECASAMENTO
}

\author{
Tese de Doutorado
}

Tese apresentada ao Departamento de Psicologia da PUC-Rio como parte dos requisitos para a obtenção do título de Doutor em Psicologia Clínica.

Orientadora: Prof ${ }^{\mathrm{a}}$. Dra . Terezinha Féres Carneiro
\end{abstract}

Volume I

Rio de Janeiro

Janeiro de 2003 
Ficha Catalográfica

Travis, Susan

Construções familiares : um estudo sobre a clínica do recasamento / Susan Travis; orientadora: Terezinha Féres Carneiro. - Rio de Janeiro : PUC, Departamento de Psicologia, 2003.

[9], 138 f. ; $30 \mathrm{~cm}$

Tese (doutorado) - Pontifícia Universidade Católica do Rio de Janeiro, Departamento de Psicologia.

Inclui referências bibliográficas.

1. Psicologia - Teses. 2. Casamento. 3. Família nuclear. 4. Recasamento. 5. Família recasada. 6. Terapia de família. I. Carneiro, Terezinha Féres. II. Pontifícia Universidade Católica do Rio de Janeiro. Departamento de Psicologia. III. Título.

CDD: 150 


\section{Susan Travis}

\section{Construções Familiares: Um Estudo Sobre a Clínica do Recasamento}

Tese apresentada como requisito parcial para obtenção do grau de Doutor em Psicologia Clínica pelo Programa de Pós-Graduação em Psicologia do Departamento de Psicologia do Centro de Teologia e de Ciências Humanas da PUC-Rio. Aprovada pela Comissão Examinadora abaixo assinada.

Profa. Profa ${ }^{\text {. Dra }}$. Terezinha Féres Carneiro

Orientador Departamento de Psicologia - PUC-Rio

Prof. Bernardo Jablonski

Departamento de Psicologia - PUC-Rio

Profa. Adriana Wagner Pontifícia Universidade Católica do Rio Grande do Sul - PUCRS

Prof. Andrea Seixas Magalhães Universidade Estácio de Sá UNESA

Profa. Monique Rose Aimée Augras Departamento de Psicologia - PUC-Rio

Prof. Jürgen Heye Coordenador Setorial do Centro de Teologia e de Ciências Humanas - PUC-Rio 
Ao meu terapeuta, por me fazer perceber a possibilidade de construir novas histórias.

À Sofia Travis Gonçalves, a mais legítima representante de gerações de famílias recasadas, pela alegria e iluminação trazidas com sua chegada.

À Jacqueline Anne Travis, por me ensinar a cada dia a conviver com as diferenças e a tentar compreende-las.

À Maria Dora Barros e Wilhelm Knoepfelmacher, por terem começado toda essa história. 


\section{Agradecimentos}

À Terezinha Féres Carneiro, orientadora da tese, pelo apoio, confiança e pela possibilidade de aceitar as transformações ocorridas ao longo de nosso trajeto.

À Monique Augras, pelo apoio e presença constantes, percebidos mesmo na sua ausência.

À Edna Ponciano, colega de doutorado, pela disponibilidade de partilhar conhecimentos, trocar idéias e discutir nossos trabalhos de forma incansável.

Ao Professor Bernardo Jablonski, pelos artigos e livros sugeridos.

À minha família e meus amigos, pelo carinho e incentivo.

Aos terapeutas entrevistados, que encontraram tempo em suas agendas para partilhar comigo suas experiências profissionais.

Ao Diretor da Faculdade de Psicologia da Universidade Católica de Petrópolis, Professor Derly Gomes de Oliveira, pela compreensão e apoio ao longo da elaboração deste trabalho.

Ao CNPq, pela ajuda financeira recebida durante o ano de 1999, e à Coordenação Central de Pós-Graduação da PUC-Rio, pela bolsa de isenção concedida nos anos subsequentes.

A Marise e Verinha, pelo apoio, que muitas vezes foi além das rotinas administrativas. 


\section{Resumo}

Travis, Susan; Féres Carneiro, Terezinha (Orientadora). Construções familiares: um estudo sobre a clínica do recasamento. Rio de Janeiro. p. Tese de Doutorado - Departamento de Psicologia, Pontifícia Universidade Católica do Rio de Janeiro.

O presente estudo tem como objetivo analisar a percepção dos terapeutas de família do Rio de Janeiro a respeito do recasamento, assim como as abordagens teórico-práticas, preferencialmente, utilizadas no atendimento a membros de famílias recasadas.

A complexidade e a diversidade presentes na estrutura das famílias recasadas, assim como o aumento constante dessa configuração familiar, indica que o modelo de família nuclear, determinante na formulação inicial de algumas abordagens de terapia de família, e ao qual as famílias recasadas são comparadas, não é um parâmetro adequado. A literatura especializada ressalta que as diferenças essenciais entre esses formatos de família devem ser consideradas pelas diferentes abordagens psicoterápicas.

Foi realizada uma pesquisa de campo, fundamentada na revisão da literatura, na qual foram entrevistados dez terapeutas de família do Rio de Janeiro. O grupo de entrevistados foi constituído por seis sujeitos do sexo feminino e quatro sujeitos do sexo masculino, todos com mais de quatorze anos de experiência clínica na área de terapia de família, inicialmente de orientação sistêmica. A partir da fundamentação teórica e do discurso dos sujeitos entrevistados, foram propostas cinco categorias de análise.

A avaliação do material obtido mostra a influência significativa do modelo de família nuclear nas formulações da maioria dos entrevistados sobre relações familiares, assim como sobre as abordagens teórico-práticas utilizadas. A maioria dos entrevistados não pareceu considerar relevante para o seu trabalho o conhecimento acerca das especificidades das famílias recasadas. Observamos, através das palavras da maioria dos entrevistados, um distanciamento entre a clínica e as pesquisas atuais sobre o tema.

\section{Palavras-chave}

Casamento, família nuclear, recasamento, família recasada, terapia de família. 


\section{Abstract}

Travis, Susan; Féres Carneiro, Terezinha (Advisor). Family constructions: A study on remarriage and its clinic. Rio de Janeiro. p. DSs. Dissertation - Departamento de Psicologia, Pontifícia Universidade Católica do Rio de Janeiro.

The purpose of the present study is to analyze the perception of the family therapists from Rio de Janeiro in relation to remarriage, and the theoretical and clinical approaches preferentially used to treat members of remarried families.

The complexity and diversity present in the structure of remarried families, as well as the increase of this family form, indicate that the nuclear family model, determinant in the formulation of the initial approaches of family therapy, and to which remarried families are compared, is not an adequate parameter. The specialized literature points out that the different psychotherapeutic approaches should consider the essential differences between these two family forms.

A field study based upon the review of the specialized literature was conducted. Ten family therapists from Rio de Janeiro were interviewed. The group was formed by six female and four male subjects. All of the subjects had more than fourteen years of clinical experience as family therapists, and initially followed a systemic orientation. Based on the theoretical framework and on the analysis of the subjects' discourse, five categories were proposed.

The final evaluation of the data demonstrates the significant influence of the nuclear family model in the formulations made by the subjects about family relations, as well as those made about the theoretical and clinical approaches used. Most of the subjects did not seem to consider the specific knowledge about remarried families relevant to his/her practice. It was possible to observe, through the words of most subjects, a distance between their clinical work and current researches on the matter.

\section{Keywords}

Marriage, nuclear family, remarriage, remarried family, family therapy. 


\section{Sumário}

Introdução

1. Construções e reconstruções do modelo familiar: casamentos, separações e recasamentos

1.1.Família: construção social e histórica

1.2. Mudança de modelo: nova definição de papéis

1.3. Ciclo de vida: papéis familiares que se constróem

no tempo

1.4. Casamento: crise e transformação da família

1.5. O casal: a construção de um mundo comum

1.6. A separação conjugal: a desconstrução de um mundo comum e um corte no ciclo de vida familiar

1.7. Recasamento: reconstrução da conjugalidade e reformulação dos papéis familiares

2. O recasamento

2.1. Famílias recasadas: o seu surgimento na clínica

2.2. Famílias recasadas: características e especificidades

2.2.1. Estrutura: como é constituída a família recasada

2.2.2. O desempenho dos papéis familiares

2.2.3. Os conflitos de lealdades gerados pelas novas relações

2.2.4. As fronteiras: o processo de inclusão e exclusão familiar

2.2.5. Expectativas

2.2.6. Responsabilidade Parentais

2.3. Famílias recasadas e terapia de família: um encontro de informações 
3.3. O construtivismo e o construcionismo social 78

3.4. A pergunta de Salvador Minuchin 83

3.5. Respostas à pergunta de Salvador Minuchin 85

3.6. Modelos e terapeutas: a clínica do recasamento 93

4. Pesquisa de campo 95

4.1. Metodologia $\quad 95$

4.1.1. Sujeitos 95

4.1.2. Instrumentos 99

4.1.3. Método 100

4.2. Análise e discussão das entrevistas 101

4.2.1. Temas e categorias de análise 101

4.2.2. $1^{\text {a }}$ Categoria: Família 102

4.2.3. $2^{\mathrm{a}}$ Categoria: Família recasada 108

4.2.4. $3^{\text {a }}$ Categoria: Transformações sociais 116

4.2.5. $4^{\text {a }}$ Categoria: Queixas relacionadas ao recasamento 123

4.2.6. $5^{\text {a }}$ Categoria: Relação teoria-prática 130

5. Considerações finais 137

6. Referências bibliográficas 141 


\section{INTRODUÇÃO}

Nosso interesse por famílias construídas através de um novo casamento, após a separação conjugal, surgiu na prática clínica, através de atendimentos individuais. Observamos que um número significativo de pessoas buscava ajuda psicoterápica por estarem experimentando algum tipo de dificuldade em relação à nova família que estava por se constituir. No presente estudo, estamos chamando este novo casamento de recasamento e a família que se inicia a partir dessa nova união do casal, de família recasada. É importante ressaltar que estamos incluindo sob a mesma nomenclatura as uniões legais e as consensuais, ou seja, aquelas em que os parceiros co-habitam formando um novo casal, sem a existência de vínculos legais.

Verificamos que os casais das camadas médias da população do Rio de Janeiro, sujeitos de nossas pesquisas exploratórias anteriores, utilizam a palavra casamento para referirem-se a uniões de caráter estável, onde partilham não apenas a residência, mas todas as atividades pertinentes a um casal num casamento reconhecido por lei. Desta forma, uma nova união com as mesmas características de partilha de residência, atividades e responsabilidades comuns constituirá um novo casamento ou um recasamento. Para esta definição, recebemos também a influência dos autores que pesquisam o tema, que chamam o novo casamento de recasamento ou "remarriage", em inglês e a família de recasada ou "remarried family" (Sager e colaboradores,1983; Woods, 1987; Visher e Visher, 1988, 1996, 1997; McGoldrick e Carter, 1989 e 1999; Brun 1999).

Concordamos com a perspectiva de McGoldrick e Carter (1999) quanto à escolha da expressão "família recasada" para descrever este formato de família. Segundo as autoras, esta expressão enfatiza a noção de que o vínculo conjugal forma a base para os envolvimentos complexos de várias famílias numa "nova constelação". Observam que nos EUA muitos desses casamentos também acontecem, pelo menos a princípio, de forma consensual. 
Embora a expressão "família recasada" seja utilizada de forma geral para definir um formato de família, a complexidade estrutural e a diversidade de configurações possíveis não nos permitem falar de uma família recasada típica. Sager e colaboradores (1983) constataram que, se levados em conta fatores como gênero, casamentos anteriores de ambos os parceiros, a existência de filhos residentes ou não, existem vinte e quatro configurações possíveis para famílias recasadas. Novos fatos, como por exemplo o nascimento de um filho dentro do recasamento, aumentam esse número. Cada configuração apresenta suas especificidades e seus conflitos. O autor cita, como exemplo de uma dessas configurações, a situação de uma jovem solteira, sem qualquer experiência de casamento anterior, que se casa com um homem separado, pai de dois filhos. Embora os filhos residam com a mãe, eles visitam o novo casal regularmente. É difícil para esta mulher imaginar ou prever que influências a presença dos enteados terá em sua nova vida familiar. É, também, imprevisível a intensidade de interações que existirá entre a nova família e a família anterior de seu marido.

A diversidade e complexidade das famílias recasadas também são mencionadas por Coleman, Ganong e Fine (2000) como fatores que dificultam a realização de pesquisas empíricas sobre o tema. Algumas dessas dificuldades são de ordem prática, visto que o custo do recrutamento de famílias que contemplem a diversidade estrutural encontrada no recasamento seria, nas palavras dos autores, proibitivamente alto.

Decidimos utilizar a definição de família recasada proposta por Visher e Visher (1988) ao longo deste trabalho, por considerá-la, ao mesmo tempo, abrangente e objetiva: "Definimos uma família recasada como um lar onde vive um casal e pelo menos um dos parceiros tem um filho de casamento anterior" (p. 9).

As razões que levam indivíduos recasados a buscarem psicoterapia são diversas, mas é possível perceber, através de seus discursos, queixas comuns. Algumas dessas queixas apontam para o que consideram uma inadequação de algum membro ou membros da nova configuração familiar ao tentarem interagir como "uma família". É comum, também, a tentativa de atribuição de responsabilidade a algum membro da família, pelo que é considerado insucesso na convivência familiar. Ou seja, ao falarem sobre os conflitos e dificuldades que os afligem, os membros da família recasada deixam claro que têm expectativas a 
respeito da nova família, além da idéia de um modelo familiar que deveria estar sendo seguido. O modelo de família que permeia o imaginário e as expectativas da sociedade contemporânea como um todo, e da própria família recasada, é o modelo da família nuclear ou família intacta, que compreende o casal e seus filhos biológicos. Como tentaremos exemplificar ao longo do trabalho, este modelo de família, assim como as expectativas de alcançá-lo, formam parte das dificuldades encontradas pelas famílias recasadas ao tentarem definir seus papéis familiares.

Quando um homem e uma mulher casam-se pela primeira vez, eles levam para o casamento a bagagem emocional, sócio-cultural e, muitas vezes, econômica de suas famílias de origem. Embora possam ter expectativas e desejos diferentes em relação ao casamento, a experiência é igualmente nova para ambos. No recasamento essa bagagem é acrescida das experiências vividas no casamento anterior, na separação e, até mesmo, no período de transição entre os diferentes relacionamentos. As experiências, neste caso, são no mínimo assimétricas.

A formação de uma nova família que inicia-se a partir da união de um casal, no primeiro casamento, acontece, na maioria das vezes, gradualmente e os eventos marcantes do ciclo de vida familiar se dão, também, de forma gradual.

O recasamento também dá início a uma nova família. Neste caso, porém, a construção familiar não acontece gradualmente. O casal recasado não dispõe da privacidade e do tempo necessários para a adaptação de uma vida comum, pois os filhos de relações anteriores, de um ou de ambos os membros do casal, já existem e demandam atenção e cuidados.

Em sua pesquisa sobre o recasamento no Brasil, Woods (1987) constatou um aumento do número de casais recasados que buscavam ajuda psicoterápica para seus conflitos conjugais, assim como a escassez de publicações nacionais que tratassem especificamente deste tipo de casal e, consequentemente, deste formato de família, que diferencia-se da família formada pelo primeiro casamento. Ao iniciarmos o presente estudo verificamos que, passada mais de uma década, a situação não é muito diferente. É crescente o número de indivíduos recasados que procuram ajuda psicológica, e são igualmente escassas as publicações que abordem o tema, levando em conta o contexto sócio-cultural brasileiro.

McGoldrick e Carter (1989) ressaltam, em seu estudo sobre o ciclo de vida familiar, a necessidade de um paradigma inteiramente novo para a família recasada, que considere a complexidade dos relacionamentos criados pela união 
do casal. Enquanto um primeiro casamento, que teve seu curso interrompido por morte ou separação, propiciou a união de duas famílias, um recasamento pode envolver três, quatro ou até mesmo mais famílias. Em um trabalho mais recente sobre o tema, McGoldrick e Carter (1999) afirmam que o processo de formação de uma família recasada é tão complexo que elas passaram a pensá-lo como o acréscimo de uma nova fase no ciclo familiar dos envolvidos.

Nos Estados Unidos as famílias recasadas estão se tornando o formato familiar mais comum. As estimativas apontam para o fato de que brevemente haverá mais famílias recasadas ou bi-nucleares (o termo bi-nuclear refere-se a criação de dois domicílios familiares, após a separação conjugal) do que nucleares (Bernstein, 1989). Hoje a metade dos casamentos que ocorrem nos Estados Unidos são recasamentos (Coleman, Ganong e Fine, 2000).

No Brasil, dados fornecidos pelo IBGE (1994) sobre casamentos, separações e recasamentos demonstram que $15 \%$ dos casamentos realizados na cidade do Rio de Janeiro são, na realidade, recasamentos. A prática clínica com casais e famílias, como foi mencionado acima, nos mostra que um número significativo de recasamentos acontece de modo consensual, sem o envolvimento de contrato ou qualquer procedimento legal. Podemos concluir, portanto, que o número de recasamentos no Rio de Janeiro é consideravelmente maior do que o apontado pelas pesquisas oficiais.

Um segundo casamento reconhecido por lei só tornou-se possível no Brasil a partir de 1977, quando o divórcio foi instituído. Até então o recasamento era um "ajuntamento", que até a década de 60 e início dos anos 70 não era socialmente bem aceito, principalmente nas camadas média e alta da população. Para minimizarem o preconceito de não terem suas uniões oficialmente reconhecidas, os separados, chamados então de desquitados, casavam no exterior, freqüentemente no Uruguai, apesar de tais casamentos não serem legalmente reconhecidos no Brasil. A sociedade brasileira estigmatizava não apenas o indivíduo desquitado como também seus filhos (Woods, 1987).

O divórcio não surgiu, no Brasil, como um dispositivo legal que poderia ser acionado quando o desejo de separar-se fosse manifestado legalmente pelo casal, ou que permitisse a dissolução de um contrato civil - o casamento - entre adultos, protegendo seus direitos e o de seus filhos. Sua obtenção era precedida de dois anos de separação judicial ou cinco anos de separação de fato. 
Atualmente, depois de algumas emendas na Lei, o divórcio tornou-se um instrumento jurídico mais ágil, facilitando a possibilidade de um recasamento legalmente reconhecido.

Enquanto esperava pela aprovação da Lei do Divórcio, a sociedade brasileira foi se modificando e a união informal entre os casais foi se tornando cada vez mais comum e aceita. Atualmente, mesmo tendo a possibilidade de recasar legalmente, muitos casais simplesmente vivem juntos.

Em 1987, Woods constatou:

\begin{abstract}
"Para o divorciado de hoje, morar juntos apenas, dá uma impressão de liberdade, simplicidade, e não comprometimento, que não existia no primeiro casamento. Esse sentimento de estar livre para partir quando quiser, parece até de certa forma contribuir para um melhor relacionamento entre os membros do casal recasado" (p.18).
\end{abstract}

A prática clínica nos mostra que se para alguns existem os sentimentos mencionados por Woods, para outros isto faz com que o recasamento pareça uma união de segunda categoria, menos qualificada socialmente, principalmente para o(a) parceiro(a) que não vivenciou a experiência de rituais, cerimônias e preparações de um primeiro casamento.

Ao esclarecer a utilização da palavra recasamento em seu livro sobre o tema, a autora e terapeuta de família brasileira, Gladis Brun (1999) comenta:

\footnotetext{
"A palavra recasamento, empregada ao longo deste livro, foi escolhida na ausência de qualquer outra que defina melhor a relação. Mas assim como as demais, seu significado está longe de expressar a singularidade dessa nova união atraindo, com o prefixo "re", idéias de repetição, reformulação e recriação. Não existe nomenclatura específica para este casamento em nenhuma língua conhecida. Só encontramos referências que nos levam a pensar em remendo, segunda mão, imitação, substituição, reconstituição, palavras e expressões com uma forte carga negativa. A família nuclear - mãe, pai e filhos - fica sendo vivenciada como a única verdadeira, valorizada, boa e legítima. Tudo que for diferente dessa familia-padrão é 'menos' “ (p.24).
}

A despeito da possibilidade legal de construir um novo casamento e da aceitação de novas uniões por uma parcela significativa da sociedade brasileira, a família recasada ainda encontra dificuldades na legitimação, aceitação e, até, nomeação das novas relações familiares.

McGoldrick e Carter (1999) descrevem as dificuldades da sociedade americana em reconhecer a família recasada como normal (palavra utilizada pelas autoras). Apontam como um dos motivos o fato da maioria das pesquisas sobre 
família focalizarem famílias intactas de primeiro casamento. Concluem que falta à cultura americana padrões estabelecidos ou rituais que ajudem os membros da nova família a lidarem com as complexas relações adquiridas através do recasamento. As autoras atribuem à conotação negativa relacionada aos termos utilizados para descrever as relações familiares criadas pelo recasamento (madrasta, padrasto e enteados), o aumento das dificuldades que os membros da família sentem para lidar com elas.

A constatação da inadequação das palavras que nomeiam as relações criadas entre os membros da nova família, é também mencionada por Sager e colaboradores (1983), Visher e Visher (1988), Osório (1996), Bernstein (1999) e Brun (1999). Uma família recasada é também chamada de reconstituída ou reconstruída, em oposição à família nuclear intacta. Na opinião de Bernstein (1999) as palavras madrasta, padrasto, enteado(a), família reconstituída, freqüentemente suscitam associações como "perversa", "abusivo", "maltratado(a)", "infeliz" ou "não tão boa quanto". A autora discute, ainda, a influência das histórias infantis clássicas no imaginário popular, onde as madrastas eram malvadas e os enteados profundamente infelizes. Além das histórias infantis, Bernstein menciona pesquisas americanas cujo discurso continua apontando as famílias recasadas como desviantes e a qualidade dos cuidados parentais como "não tão bons", o que resultaria em privações e, até, maus tratos.

Brun (1999) também atribui ao que chamou de "ausência de códigos linguísticos para o recasamento", a geração de tensões que prejudicam a acomodação dos membros desta família em seus novos papéis.

Em uma revisão bibliográfica onde foram examinadas 850 publicações sobre o recasamento na década de 90, Coleman. Ganong e Fine (2000) afirmam que os trabalhos que versam sobre a visão social americana prevalente acerca das famílias recasadas é que elas são desviantes e que são ambientes prejudiciais para crianças e adolescentes. São também estigmatizadas através de rótulos, estereótipos e mitos culturais. Os autores acrescentam que os comportamentos e atitudes dos profissionais que lidam com essas famílias, também são afetados pelos estereótipos negativos a respeito de padrastos e madrastas. Observam, ainda, que quando as famílias recasadas não são estigmatizadas, elas tornam-se invisíveis aos sistemas sociais, uma vez que as políticas e práticas escolares, assim como as 
organizações de jovens criam barreiras à participação de membros de família recasadas, visto que são baseadas em modelos de famílias de primeiro casamento. Sobre modelo familiar e sua influência nas terapias de família Ponciano (1999) observa:

\begin{abstract}
"Entendemos que o modelo de família está relacionado com e determina a intervenção terapêutica. Originalmente, a Terapia de Família, orientada pela Teoria dos Sistemas (anos 50 e 60), é, quase exclusivamente, influenciada pelo modelo de família conjugal constituído na modernidade. No decurso de suas formulações posteriores, entretanto, esse modelo começa a ser questionado principalmente em sua característica nuclear, preservando noções como as de intimidade, privacidade e posicionando- se de diferentes maneiras frente à composição familiar que irá ser parte do contexto da intervenção" (p.33).
\end{abstract}

$\mathrm{Na}$ sua grande maioria, contudo, os terapeutas de família de orientação sistêmica partem do modelo de família nuclear para pensar as questões que afligem seus pacientes. Entretanto, as transformações sofridas pela família nas três últimas décadas, que serão discutidas ao longo do trabalho, impõem transformações não só na prática clínica, como nas considerações teóricas a respeito do tema.

Verificamos que a literatura utilizada para estudos sobre o recasamento provém, em grande parte, de terapeutas sistêmicos americanos. É importante observar que esses terapeutas também foram levados a desenvolver pesquisas clínicas sobre o tema, tendo em vista o aumento do número de famílias recasadas que recorriam às clínicas de terapia de família. Embora a relevância das pesquisas americanas seja evidente para nós, não podemos deixar de levar em conta as variáveis do contexto sócio-cultural brasileiro, quando tentamos empreender um estudo sobre um tema ao mesmo tempo tão universal e tão local como a família.

É a partir de fatos como a escassez de publicações nacionais a respeito das diversas situações vividas por membros de famílias recasadas, o aumento constante deste formato de família, assim como a sua busca por ajuda psicoterápica que decidimos elaborar esta pesquisa. A proposta do presente estudo é verificar, através de uma pesquisa de campo com terapeutas de família do Rio de Janeiro, a percepção desses terapeutas em relação às famílias recasadas, e às abordagens terapêuticas por eles utilizadas no tratamento das famílias constituídas a partir do recasamento. Partindo da premissa que a prática clínica de 
um terapeuta de família é influenciada por sua noção de um modelo de família, paralelamente ao desenvolvimento da proposta acima mencionada, é nosso objetivo investigar o modelo de família que norteia as práticas clínicas dos sujeitos entrevistados. Para tal, buscaremos compreender as seguintes questões relacionadas entre si: Como o modelo de família nuclear influiu e influi na formulação da prática clínica de terapia de família? O recasamento, enquanto desafio a este modelo, representa uma transformação para a clínica?

A pesquisa está desenvolvida em cinco capítulos. No capítulo1 procuramos acompanhar o percurso e as transformações ocorridas na noção de família, ou seja, buscamos uma contextualização sócio-histórica do modelo de família nuclear moderna. Os temas casamento, separação conjugal e recasamento são abordados neste capítulo, através de uma revisão da literatura que inclui autores da sociologia, da psicologia e da história da família. No capítulo 2 apresentamos estudos de terapeutas de família de orientação sistêmica sobre o recasamento, assim como pesquisas que abordam o tema a partir de perspectivas diversas. Nosso objetivo neste capítulo é identificar as especificidades inerentes às relações familiares no recasamento, os potenciais conflitos nas relações entre seus membros, assim como as abordagens terapêuticas utilizadas para atendê-los. Nosso propósito, em relação ao capítulo 3, não é discorrer sobre a história da Terapia de Família, mas fazer uma articulação entre a revisão da literatura sobre o tema e as abordagens teórico-práticas mais utilizadas pelos terapeutas de família do Rio de Janeiro. A elaboração deste capítulo, portanto, está dividida em duas etapas. Na primeira fazemos uma revisão da literatura relacionada às terapias de família de orientação sistêmica. Como nosso objetivo é apresentar as abordagens teórico-práticas mencionadas pelos terapeutas entrevistados no estudo de campo, foi necessário que tivéssemos realizado as entrevistas para que pudéssemos concluir o capítulo. Utilizando as informações fornecidas pelos entrevistados, elaboramos um capítulo que percorre a noção de família e de especialista, desde Salvador Minuchin aos terapeutas construtivistas/construcionistas sociais. No capítulo 4 apresentaremos a metodologia utilizada na pesquisa de campo com terapeutas de família do Rio de Janeiro, além da análise e discussão das entrevistas realizadas. Procuramos articular os dados obtidos nas entrevistas com os temas desenvolvidos nos capítulos anteriores. No último capítulo 
apresentaremos nossas considerações finais, desenvolvidas a partir dos resultados do estudo de campo.

Acreditamos que a ampliação do conhecimento teórico-prático relativo às características específicas das famílias recasadas e ao seu tratamento psicoterápico, contribui para a prática clínica e para o desenvolvimento de novas pesquisas sobre o recasamento e sobre outras configurações familiares que afastam-se do modelo de família nuclear. Desejamos, assim, que a nossa pesquisa traga mais questões para os que se interessam em refletir a respeito de sua prática clínica com famílias. 
1

\title{
Construções e Reconstruções do Modelo Familiar: Casamentos, Separações e Recasamentos
}

\section{1}

\section{Família: Construção Histórica e Social}

\begin{abstract}
“Como principal agente da socialização, a família reproduz padrões culturais no indivíduo. Não só confere normas éticas, proporcionando à criança sua primeira instrução sobre as regras sociais predominantes, mas também molda profundamente seu caráter utilizando vias das quais nem sempre ela tem consciência. A família inculca modos de pensar e de atuar que se transformam em hábitos. Devido à sua enorme influência emocional, afeta toda a experiência anterior da criança" (Lasch, C., 1991, p.25).
\end{abstract}

A forma como as famílias se constróem, ou seja, a escolha do cônjuge, quem é considerado membro da família, a co-residência como fator de inclusão familiar, os laços sangüíneos, os laços criados a partir do casamento, tem passado por diversas transformações ao longo do tempo. Assim como têm se transformado a forma de investigação e os estudos sobre o tema. As primeiras pesquisas sobre o recasamento, por exemplo, focalizavam sua atenção para os problemas enfrentados pelas famílias recasadas que, comparadas às famílias biológicas, eram avaliadas negativamente. Os estudos mais recentes, porém, estão considerando a complexidade estrutural e a diversidade de configurações possíveis das famílias recasadas, além de procurar entender as especificidades deste formato de família. O redirecionamento das pesquisas nos leva a pensar que essas transformações também devam ser investigadas no campo da terapia de família.

Observamos que os autores citados neste breve histórico, sociólogos e historiadores inseridos num campo de discussão sobre a família, apresentam algumas divergências de opiniões. Não é nossa intenção, contudo, aprofundarmonos no tema, mas apresentar, sucintamente, o argumento sobre a construção sócio-histórica da família moderna, como um consenso entre esses autores. Procuraremos, através das transformações sócio-históricas que dão origem ao modelo de família nuclear moderna, indicações que nos permitam pensar as 
relações familiares no recasamento, fenômeno sócio-familiar que desafia aquele modelo.

Comecemos por Segalen (1996) que faz uma crítica à sociologia ahistórica, enfatizando a importância da perspectiva histórica nos estudos sociais relacionados à família. É a introdução da perspectiva histórica na sociologia da família que possibilita a compreensão de que "cada época conhece as suas formas familiares; sociedade e família são o produto de forças sociais, econômicas e culturais comuns, sem que seja o resultado uma da outra" (p.10). A autora observa que é através dos estudos históricos que se evidencia o fato de a família ser uma instituição em contínua mutação, um conjunto de processos. Constata o poder de resistência e a capacidade de adaptação da família, observando que "foram poucas as instituições que conseguiram atravessar as mudanças econômicas e sociais fundamentais que transformaram as sociedades baseadas numa economia agrária em sociedades baseadas numa economia industrial e pós-industrial” (p. 10).

Philippe Ariès (1973) associa o nascimento da família moderna a mudanças ocorridas no final do século XVII e no século XVIII em relação ao tratamento dado às crianças e à vida privada. Até então crianças e adultos misturavam-se na comunidade, participando de todos os eventos públicos da coletividade. Para o autor, nessas existências "densas e coletivas", não havia lugar para um setor privado. A função da família era, então, a de transmissão de vida, de bens e de nome. A preocupação com a educação infantil, no início dos tempos modernos, foi, na opinião de Ariès (1973) um acontecimento marcante na transformação da família, surgindo como mais um fator relevante em sua privatização e modernização. Os filhos tornam-se o centro das atenções, podendo se observar um prolongamento da infância, que passa a ser protegida e controlada. Novos sentimentos surgiram a partir dos cuidados com a educação das crianças e de sua separação das atividades dos adultos: o sentimento de infância e o sentimento moderno de família.

Para Ariès, a separação da criança do mundo dos adultos veio ao encontro de uma necessidade de intimidade e de identidade dos adultos, visto que os membros da família se "unem pelo sentimento, o costume e o gênero de vida". O autor comenta que a necessidade de afastamento da promiscuidade das multidões foi um fenômeno proveniente da burguesia. Aponta, desta forma, para uma 
relação entre o sentimento de família e o sentimento de classe. Nas palavras do autor:

\footnotetext{
"A procura da intimidade e as novas necessidades de conforto que ela suscitava (pois existe uma relação estreita entre o conforto e a intimidade) acentuavam ainda mais o contraste entre os tipos de vida material do povo e da burguesia. A antiga sociedade concentrava um número máximo de gêneros de vida num mínimo de espaço, e aceitava - quando não procurava - a aproximação barroca das condições sociais mais distantes. A nova sociedade, ao contrário, assegurava a cada gênero de vida um espaço reservado, cujas características dominantes deviam ser respeitadas: cada pessoa devia parecer com um modelo convencional, com um tipo ideal, nunca se afastando dele, sob pena de excomunhão. O sentimento de família, o sentimento de classe e talvez, o sentimento de raça surgem portanto como manifestações da mesma intolerância diante da diversidade, de uma mesma preocupação de uniformidade" (Ariès, 1973, p.279).
}

Segundo Ariès, a organização das casas no século XVIII já mostrava a nova preocupação com a privacidade e de defesa contra o mundo. Passa a existir, então, uma especialização dos cômodos: quartos eram destinados apenas para dormir, enquanto a sala era o cômodo onde se faziam as refeições ou se recebiam as pessoas. Havia independência entre os cômodos e áreas separadas para os criados. $\mathrm{O}$ autor observa que o conforto, a intimidade, a discrição e o isolamento, surgidos inicialmente entre a burguesia e a nobreza, datam desta época e marcam uma das maiores mudanças na vida quotidiana.

Podemos concluir que o passado e o presente da família são elementos indissociáveis, na tentativa de compreendermos seu processo contemporâneo de construção. O recasamento contemporâneo, ou a reconstrução da situação conjugal com um novo cônjuge, é um processo de construção conjugal e familiar, que se apresenta, ao mesmo tempo, como uma possibilidade de rompimento ou de desvio do modelo sócio-histórico de família moderna que, conforme nos mostra Ariès, marca a intolerância diante da diversidade.

\section{2}

\section{Mudança de Modelo: Nova Definição de Papéis}

A figura da mãe aparece no centro deste novo projeto familiar de educação e proteção dos filhos. Saraceno (1997) confirma que a família moderna, como a família dos sentimentos e da educação, nasce em torno das figuras da mãe e da criança. Para a autora, essas figuras interdependentes estão circunscritas a um 
espaço que é cada vez mais doméstico e familiar. Acrescenta que, como parte do projeto educativo, médicos, reformadores e os próprios maridos insistiam para que as mulheres assumissem os cuidados dos filhos, renunciando ao uso das amas, a quem durante séculos haviam confiado suas crianças. Surgia, então, o sentimento de maternidade, criado em nome de uma maior segurança higiênicosanitária e de uma maior moralidade e responsabilidade, construído social e culturalmente. Sobre a figura do pai, construída paralelamente, a autora afirma que o processo é menos "explícito e linear". Mantendo as características de poder e autoridade da forma de família que precedia este novo formato, os "maridospais" tomam para si a função de promover, em sua própria família, os "novos modelos pedagógicos e higiênicos-sanitários", relacionados aos seus filhos e esposas. Contam, porém, com a ajuda de médicos, padres e moralistas (Saraceno, 1997, p.132).

Paralelamente à nova função das mães, em relação à educação e aos cuidados com as crianças, surge, no século XIX, a necessidade de regulação ou controle do número de filhos. São utilizados métodos contraceptivos "naturais", o que produz uma modificação profunda nas relações entre os cônjuges e na interpretação da sexualidade. A contracepção aparece como uma atitude revolucionária, visto que o ato sexual parecia ser exclusivamente comandado pela natureza. A doutrina eclesiástica desencorajava a contracepção, a medida que sexualidade conjugal só deveria ser exercida com o objetivo de procriação. Neste primeiro momento a responsabilidade e o controle sobre a contracepção é masculino, “onde o homem controla a sua pulsão sexual para se retirar no momento de mais intenso prazer" (Segalen, 1996, p.178).

Há, nas palavras de Saraceno (1997), uma redefinição das relações homem-mulher e dos papéis sexuais. Podemos perceber uma forma inicial de construção do casal conjugal moderno, que começa a decidir sobre sua sexualidade e o tamanho de sua própria família. Na sociedade, a decisão do casal de controlar o tamanho de sua família, é traduzida como uma queda na fecundidade das mulheres.

Muito mais tarde, a partir da década de 70 do século $\mathrm{XX}$, deu-se o fenômeno que Segalen (1996) chamou de "a segunda revolução contraceptiva", que tornou-se parte dos hábitos dos indivíduos através da pílula anticoncepcional e dos dispositivos intra-uterinos. As diferenças entre as duas revoluções é que na 
última a contracepção é feminina. Na opinião da autora, embora ambas tenham a mesma finalidade, o controle da natalidade, representam relações muito diferentes com a sociedade.

À medida que consideramos a união do casal a base sobre a qual será construída a família, estamos de acordo com o comentário de Segalen (1996) quanto ao fato de que o casamento, mais do que qualquer outro fenômeno da instituição familiar, deve ser estudado numa perspectiva histórica. A autora observa que, em relação às transformações do casamento, a realidade sociológica evolui mais rapidamente do que a formulação de explicações sobre ela, já que esta exige uma série de procedimentos de investigação que demandam tempo.

Visto que o casamento tinha um papel fundamental na continuidade familiar nas sociedades antigas, as estratégias familiares para a escolha do cônjuge eram regidas por um conjunto de mecanismos sociais, que levavam em conta fatores como as alianças entre parentelas, além das possíveis vantagens e potencialidades do que viria a ser a união das famílias. Na realidade, a relevância do casamento estava relacionada a uma associação de famílias, e não ao amor ou aos desejos individuais de cada membro do casal. Embora a dimensão sentimental, em relação ao casamento, esteja presente em qualquer sociedade, o amor foi considerado como "potencialmente perigoso e destrutivo das estratégias familiares e mesmo da estabilidade matrimonial" pelas sociedades tradicionais (Saraceno, 1997), não tendo o seu valor reconhecido nas escolhas conjugais, ao contrário do respeito, da deferência e dos interesses familiares. Nas sociedades ocidentais contemporâneas, contudo, é possível perceber-se uma orientação na socialização dos indivíduos para que se apaixonem, visto que o amor deve ser o motivo fundamental na escolha do cônjuge. Sobre as estratégias familiares implicadas na escolha do cônjuge, Saraceno (1997) comenta que "nada parece mais distante da cultura e das representações sociais contemporâneas sobre o casamento do que a linguagem das estratégias familiares ...” (p.96). Já na década de 50 do século $\mathrm{XX}$, o discurso sobre a escolha do cônjuge mostrava que o encontro das pessoas se dava ao acaso e os casamentos aconteciam por amor. A continuidade do casamento também se devia ao amor, da mesma maneira que a falta de amor apresentava-se como motivo suficiente para que um casamento fosse terminado. 
Podemos concluir que a forma socialmente aceita para a escolha do cônjuge e a estrutura das relações sociais e familiares estão estreitamente relacionadas. Goode (1964) mostra as transformações sociais e familiares, resultantes da possibilidade contemporânea de escolha amorosa, fundamentada na ideologia do amor. O autor observa que, a partir da existência de uma maior autonomia espacial, econômica e social do casal, em relação à família extensa, eles passam a concentrar-se mais na relação conjugal, buscando solidariedade, afeto e apoio um no outro, construindo, assim, um modelo matrimonial baseado na intimidade e na cumplicidade entre os cônjuges.

A possibilidade de fortalecimento da unidade conjugal, resultante de uma maior autonomia e de maior privacidade do casal, é apenas um dos aspectos das transformações no modelo de casamento. À medida que este modelo pressupõe igualdade e reciprocidade afetiva entre os parceiros, acaba por desencadear uma série de questionamentos quanto ao lugar ocupado pelo homem e pela mulher, não apenas dentro da relação mas, também, no plano social. A divisão de tarefas, a liberdade individual, a liberdade proporcionada pelo trabalho, a possibilidade de transitar por território público, acabam por trazer à tona novas questões acerca da relação conjugal.

Saraceno (1997) frisa que foram inúmeras as transformações históricas e culturais que resultaram no modelo de casamento contemporâneo ocidental. Observa, ainda, a diferença de tempo necessária para que as transformações ocorram nas diferentes regiões e nas diferentes classes sociais.

\section{3}

\section{Ciclo de Vida: Papéis Familiares que se Constroem no Tempo}

$\mathrm{Na}$ opinião de Segalen (1996), as transformações que mais alteraram o cenário familiar, não foram as novas formas de constituição do casal, mas o que chamou de dimensão de longo prazo da família. Para a autora, "tanto quanto na constituição do casal e no nascimento dos filhos, a família baseia-se na duração e na continuidade" (p. 215). Ao falar sobre a continuidade familiar, Segalen (1996) discute a importância do aumento da expectativa de vida nos estudos sobre a família. Segunda a autora, a coexistência de várias gerações aponta para a necessidade de uma revisão paradigmática importante. Se para os demógrafos 
cabe avaliar o peso das pessoas idosas na sociedade, para os políticos a preocupação gira em torno do custo social e financeiro deste novo fenômeno social e, para os sociólogos cabe considerar os efeitos do prolongamento da expectativa de vida na família, não apenas do ponto de vista do casal, mas do das gerações.

Em seu trabalho sobre a crise do casamento contemporâneo, Jablonski (1991) discute o papel da longevidade nos casamentos. O autor mostra que, casais que se unem por volta dos vinte anos hoje podem antever, se não se separarem, “ quase cinquenta anos de uma união monogâmica e indissolúvel, sendo boa parte desse período já sem crianças pequenas necessitando de atenção e cuidados“ (p.88). Considerando que a permanência não é uma característica dos tempos atuais (sejam eles chamados modernos ou pós-modernos), e que a ausência de filhos pequenos desloca as atenções dos membros do casal para a relação conjugal, o autor comenta que o juramento "até que a morte os separe" torna-se, cada vez mais, uma tarefa complexa a ser cumprida.

O interesse pela dimensão de longo prazo levou à criação de ferramentas de investigação, que, a partir dos anos 70 aparecem com denominações como "idades da vida", "biografia", "itinerário", "ciclo de vida", "percurso", etc. Segalen (1996) observa que essas expressões designam situações e contextos diferentes e que a "sociologia vertical" ainda não chegou a um acordo quanto às palavras. Em uma análise crítica sobre o quadro do ciclo de vida familiar, utilizado para analisar amostras familiares, a autora observa que o instrumento é muito marcado pelo seu tempo, pelo seu meio e analisa a família de classe média americana, dificilmente podendo ser utilizado para a análise de outros modelos de família. Na opinião da autora, o quadro do ciclo de vida familiar poderia ter uma utilização descritiva, mas falta consenso quanto aos critérios de divisão do ciclo em fases, o que põe em dúvida o valor analítico do instrumento. Em contrapartida, Segalen analisa um outro instrumento chamado "family life course" (curso de vida familiar), desenvolvido por um sociólogo, Glen Elder e por uma historiadora, Tamara Hareven (1991), que “associa às etapas importantes da vida (a entrada no mercado de trabalho, o casamento, a reforma, etc.) as transformações familiares, por um lado, e as transformações sociais, por outro" (p.217). Ou seja, enquanto a análise do ciclo de vida familiar permite observar as transformações de uma família, no caso da sociologia americana, uma família nuclear, o "family life 
course" permite a análise das interações entre trajetórias individuais, transformações familiares ao longo do tempo e transformações sociais nas suas repercussões cruzadas (desemprego, guerras, mudanças, etc).

A divisão do ciclo de vida familiar em oito etapas foi feita a primeira vez por E.Duvall em 1957. Cerveny (1997) explica que a divisão foi organizada em torno de "fatos nodais, entradas e saídas dos membros da família". A autora, que fez um estudo sobre a família paulista e desenvolveu uma divisão do ciclo de vida familiar baseada na realidade socio-cultural local, cita o trabalho de Carter, McGoldrick e colaboradores (1995) como o mais completo sobre o tema. Em 1999, Carter e McGoldrick apresentaram uma nova versão de seu trabalho (ainda não traduzida para o português), onde incluíram a perspectiva social ao lado das perspectivas individual e familiar.

As etapas do ciclo vital da família sucedem-se a partir de eventos nodais ou críticos, que implicam na necessidade de transformações emocionais e comportamentais por parte dos membros da família, definindo novos papéis. A chegada do primeiro filho, por exemplo, exige uma série de adaptações aos membros do casal, acostumados a um determinado estilo de vida. As transformações desencadeadas por este evento podem abranger diversos aspectos do cotidiano do casal, modificando sua rotina social, financeira, familiar, além de envolver aspectos emocionais.

Embora considerado um instrumento de natureza descritiva, a análise do ciclo de vida familiar é utilizada por terapeutas de família para contextualizar o percurso da família e de seus membros. A noção de continuidade e de construções familiares, demonstrada através de fases da vida do casal e do desenvolvimento de seus filhos, é importante para entendermos as conseqüências das desconstruções, trazidas para as famílias através da separação conjugal, assim como os impasses produzidos pela reconstrução da vida conjugal, através do recasamento.

\section{4}

\section{Casamento: Crise e Transformação da Família}

Uma revisão da literatura sobre família e casamento permite-nos observar que a palavra "crise" está bastante relacionada ao tema, em diversos períodos da história. Este fato leva-nos a acreditar que, mudanças sócio-culturais que por 
algum motivo desencadeiem alterações no funcionamento ou na estrutura famíliar, num dado período, são consideradas sinais de "crise". Ao discorrer sobre a formação da família moderna, Lasch (1991) observa sua posição fundamental:

\footnotetext{
“De todas as instituições, a família é a que mais resiste à mudança. No entanto, dada a sua importância, as mudanças em seu tamanho e estrutura, em sua organização emocional e em suas relações com o mundo externo têm uma enorme influência sobre o desenvolvimento da personalidade. Por sua vez, as mudanças na estrutura do caráter acompanham ou sustentam as mudanças na vida econômica e política" (Lash, C., 1991, p.26).
}

Segalen (1996) afirma que o discurso sobre a crise da família não é novo, tendo sido "recorrente ao longo de todo o século XIX, quando a instabilidade familiar dos grupos operários proletarizados inquietava as famílias burguesas" (p.9).

Famílias e uniões de casais, ou casamentos, são termos indissociáveis. Uma crise na família, como instituição, é uma crise no casamento e vice- versa. À medida que família e sociedade influenciam-se mútua e continuamente, é possível entender as resistências às mudanças que ocorrem em ambas.

Fazendo uma breve retrospectiva das mudanças ocorridas no casamento nos últimos 50 anos na Europa, Segalen (1996) mostra que, primeiramente, nas décadas de 50 e 60 difundiu-se a livre escolha do cônjuge, calcada na importância conferida ao amor. O culto ao amor levou os jovens a uma nova forma de conjugalidade, a coabitação, que segundo a autora parecia uma preparação para o casamento. No final da década de 80, o que parecia uma preparação para o casamento deu lugar, para uma parte significativa da população, a uma "recusa do casamento institucionalizado". A autora mostra que, ao mesmo tempo que os casais relutam em tornar legais suas uniões, verifica-se, durante a década de 70, que as uniões legalizadas terminam cada vez mais freqüentemente em divórcio. $\mathrm{O}$ casamento já não é mais visto como a única maneira de fundar uma família. A queda na taxa de fecundidade acompanha a redefinição dos laços conjugais. A autora conclui que, se até 1970 "a constituição familiar parecia orientar-se por um modelo único", no final do século XX se caracteriza a opção pela diversidade.

Casamentos legais, religiosos ou uniões informais são maneiras diferentes de formação de um casal e, consequentemente, de dar início a uma família. Cada 
sociedade, contudo, valoriza, aceita ou discrimina as uniões, com base em seus princípios culturais, religiosos ou legais. Assim como é atribuída uma valorização social diferente para cada tipo de arranjo conjugal, as famílias iniciadas a partir dessas uniões também recebem um grau maior ou menor de "oficialização" perante os olhos da sociedade. No Brasil, novas leis estão regulamentando os direitos familiares das uniões consensuais diminuindo, pelo menos legalmente, a noção de "mais" ou "menos" família ou casal.

As mudanças contemporâneas no significado do casamento alteram, também, seu lugar no quadro do ciclo de vida familiar, mencionado no item anterior. McGoldrick (1999) observa que, atualmente nos EUA, embora os casais iniciem a vida sexual mais cedo, eles estão decidindo casar-se cada vez mais tarde. Uma grande parte dos jovens vive em uniões informais antes do casamento. Mais da metade dos casamentos são precedidos por um período de co-habitação. O casamento, que no passado representava um marco de transição para a vida adulta, hoje reflete uma continuidade desta etapa, visto que o nascimento dos filhos está sendo adiado cada vez mais, principalmente nas camadas médias e altas da população.

Na opinião de McGoldrick (1999), o dilema existencial de tornar-se um casal é, provavelmente, o maior entre os demais do ciclo vital. A autora esclarece a razão disto, observando que o casamento é a única relação familiar que juramos ser "exclusiva" e "para sempre", embora seja a relação onde exista a menor probabilidade do juramento ser cumprido.

\section{5}

\section{O Casal: A Construção de um Mundo Comum}

Atualmente, os ideais de realização pessoal e autonomia são culturalmente bastante valorizados e, segundo Willi (1993), não se adequam ao ideal de casamento, que por definição não é uma união livre, mas um compromisso. $\mathrm{O}$ autor vai além, observando que o casamento "é tido como uma prisão, um amor forçado, formal e institucionalizado, que restringe o espaço evolutivo e obriga os cônjuges a levarem uma vida burguesa, caseira e chata" (p.38). Por outro lado, aponta para estatísticas epidemológicas que demonstram que as pessoas casadas apresentam melhores resultados em pesquisas sobre distúrbios psíquicos ou 
somáticos, índice de mortalidade, doenças psicossomáticas, drogas, alcoolismo, número de infartos, suicídios, etc, do que as pessoas divorciadas ou viúvas. Menciona, também, resultados de pesquisas sobre satisfação com a própria vida, dedicação e sucesso profissional, onde as pessoas casadas aparecem melhor situadas do que aquelas sem parceiros. Questiona-se sobre o paradoxo: como se explica que as pessoas casadas apresentem um estado físico e psíquico aparentemente melhor do que as não casadas, se o casamento representa um cerceamento da liberdade pessoal, um fator de diminuição de autonomia, enfim, um evento limitador do desenvolvimento pessoal? Willi procura, primeiramente, uma explicação na psiquiatria, que busca nas bases genéticas e na estrutura psicofísica do indivíduo suas respostas. $\mathrm{O}$ ponto de vista psiquiátrico inverte a questão, esclarecendo que não é pelo fato de serem casadas que as pessoas apresentam resultados melhores nas pesquisas, mas por serem mais "estáveis e mais sólidas no plano emocional e físico são mais capazes de se empenhar no casamento". O autor discorda de tal explicação e propõe que se investigue em que medidas são satisfeitas, no casamento, as relações com o mundo, a construção da realidade.

Discorrendo sobre a especificidade da relação conjugal, Willi (1993) afirma que o casamento é uma relação diferente de todas as outras, na qual os parceiros se comprometem numa história comum e onde cada um é, realmente, afetado pelo comportamento do outro. Quando decidem viver juntos, cada cônjuge deve modificar-se internamente e organizar-se, pois a partir de então, juntos, iniciarão a construção de um mundo comum. Na opinião do autor, o casamento transforma a imagem de realidade dos parceiros, além de enfatizar certos aspectos da vida cotidiana. A colaboração, por exemplo, passa a ocupar uma posição central na vida dos cônjuges, que juntos criam obras, educam os filhos, constróem um lar e buscam uma segurança existencial comum. É evidente que a liberdade, as escolhas pessoais e a sensação de independência ficam reduzidas no casamento. Se as decisões individuais de cada parceiro acabam por afetar o casal, é esperado que as divergências ocorram.

Comparando a dimensão histórica que distingue o casamento de uma aventura amorosa, Willi (1993) define o casamento como o desejo de se fundar uma família, cujos frutos contribuirão para a continuidade histórica, e não serão apagados pelo divórcio ou pela morte. 
Em artigo clássico sobre a construção social da realidade, Berger e Kellner (1964) consideram o casamento um instrumento crucial de construção nômica. Sua função social é, na opinião dos autores, a de criar para o indivíduo uma ordem tal que o faça experimentar a vida como tendo um certo sentido, e o parceiro torna-se o co-habitante mais próximo e mais decisivo do mundo. Descrevem a posição ocupada pelo casamento como absolutamente privilegiada dentre as relações significativas validadas pelos adultos na sociedade contemporânea. Uma mudança de vida drástica, de acordo com a qual todas as outras relações significativas devem ser quase que automaticamente reavaliadas e reagrupadas.

Os autores partem do que chamam de uma proposição sociológica geral, que diz que a realidade do mundo é sustentada através de conversas com outros significativos. Partindo dessa proposição, descrevem a construção deste mundo comum privado e sua importância para o casal. Comparam a amplitude das comunidades onde casamento e a família eram inseridas, no passado, com a sociedade contemporânea, na qual cada família constitui seu próprio mundo, com regras e controles próprios e suas conversas fechadas. De certa forma, essa "privatização" familiar acaba impondo ao casal uma tarefa mais árdua na construção de seu pequeno mundo. É como se cada casal tivesse que "inventar" a sua relação.

Através da conversa conjugal diária o casal constrói não apenas a realidade presente, mas reconstrói a realidade passada, fabricando, segundo Berger e Kellner, uma memória comum que integra as memórias de seus passados individuais. Consequentemente, projetos futuros também são comuns, o que dá ao casal uma sensação de estabilidade e segurança, embora limite, inevitavelmente, as projeções futuras individuais. Na terapia de família, a ênfase sobre o casal também aparece como uma forma de construir o mundo e de determinação da saúde.

\section{6}

\section{Separação Conjugal: A Desconstrução de um Mundo Comum e um Corte no Ciclo de Vida Familiar}

Embora nosso maior interesse, na análise da separação conjugal, sejam as conseqüências e impactos que este fenômeno carrega para o recasamento, 
entendemos que, mais uma vez, não podemos ignorar a perspectiva histórica relacionada ao tema. A maneira como uma sociedade lida com a questão legal e com as implicações familiares da separação conjugal, informa aos que a constituem sobre as possíveis conseqüências que advirão deste ato. Este conjunto de informações aplica-se tanto a questões objetivas, como guarda dos filhos, divisão de bens, responsabilidades financeiras, quanto ao grau de integração e aceitação dos membros da família nesta sociedade, assim como a possibilidade de reconstrução da situação conjugal com outros parceiros. Falando sobre o divórcio na França, Segalen (1999) afirma:

\footnotetext{
"Tal como o casamento, o divórcio mudou. Ainda recentemente indício de uma instabilidade familiar, de uma crise do indivíduo e da sociedade, sanção de um delito contra o outro parceiro, o casal, os filhos, a família e a sociedade, tornou-se corrente e banalizou-se" (p.158).
}

Fazendo uma retrospectiva histórica do divórcio, a autora observa que quando, na época da Revolução Francesa, o sacramento eclesiástico indissolúvel do matrimonio foi transformado em um contrato civil, a possibilidade do divórcio surgiu, visto que "todo contrato entre duas partes pode ser quebrado voluntariamente". A partir de então, em 1792, foi votada uma lei que instituía um divórcio considerado muito liberal. Se para alguns esta liberalidade agradava, para outros setores da sociedade apresentava-se como uma tentativa de destruição da família. Com a instauração da ordem napoleonica, há uma reformulação na lei, que a partir de 1804 instaura um divórcio-sanção por delito contra a ordem familiar e social. Após passar por mais duas reformulações, que, embora restritas, acabam deixando ao juiz o poder de apreciação, em 1975, uma nova lei prevê o divórcio por consentimento mútuo dos cônjuges. A autora conclui que, por apresentar-se como uma lei totalmente anacrônica em relação aos fatos contemporâneos, efetuou-se a mudança.

De acordo com Ahrons (1999), nos EUA, nos três últimos séculos, as taxas de divórcio têm mantido uma curva ascendente. O ponto mais alto foi atingido em fins da década de 70, e a oscilação parece acompanhar o ritmo da economia: em tempos de prosperidade econômica a taxa sobe, vindo a cair novamente nos momentos de menor prosperidade. O primeiro divórcio, historicamente registrado, aconteceu em 1639, mas a autora comenta que desde o fim do século XVIII, as 
altas taxas de divórcio eram motivo de debates públicos e legais, assim como era debatido se as leis que o regulamentavam deveriam ser mais ou menos liberais. Embora a lei varie de estado para estado, todos os estados americanos apresentam, atualmente, formas de divórcios consensuais e relativamente ágeis.

No Brasil o divórcio foi instituído em 1977, depois de uma longa batalha política. Brito (1993) comenta que os juristas brasileiros são unânimes em afirmar que a Lei 6515 de 26 de dezembro de 1977, conhecida popularmente como Lei do Divórcio, "foi a mais relevante nos tempos atuais no que diz respeito ao Direito de Família no Brasil " (p.56).

Toda a questão da indissolubilidade do vínculo matrimonial no Brasil e, consequentemente, da impossibilidade de constituir um segundo casamento legalmente reconhecido, teve origem na influência da Igreja Católica em nossa sociedade, e foi fortemente revalidada pelo Estado. Alguns políticos brasileiros, como o falecido Senador Nelson Carneiro, fizeram da defesa da adoção do divórcio sua plataforma eleitoral e longas batalhas foram travadas. Há cinqüenta anos atrás, o jornal $\mathrm{O}$ Globo publicava a seguinte notícia, sob o título "Fogo aberto contra o projeto de Carneiro", quando o Senador era Deputado:

\footnotetext{
"A discussão que se levantou ontem no plenário da Câmara, com a veemente defesa do deputado Nelson Carneiro fez de seu projeto de anulação do casamento, envolveu declarações de nulidade pronunciadas pela própria Igreja em vários casos. Outro parlamentar, monsenhor Arruda Câmara, antecipou ao Globo os pontos do discurso que pronunciará a propósito: - No Direito Canônico, como no Direito Civil, há causas de nulidade e anulação de casamento, que não podem, entretanto, ser confundidas com o divórcio, pois que neste se dissolve o vínculo de casamento válido, e na anulação apenas se declara que foi inexistente o matrimônio, não tendo havido o vínculo. $\mathrm{O}$ projeto que se discute anula casamentos válidos, atos jurídicos perfeitos, imitando tudo a legislação de países divorcístas. Quanto à Igreja, sua doutrina está no Cânon 1.118 "O matrimônio válido, rato e consumado, não pode ser dissolvido por poder humano algum e por nenhuma causa a não ser pela morte”. (O Globo, 23 de agosto de 1951).
}

Pelo argumento apresentado no artigo, é possível vislumbrar as lutas empreendidas para que o divórcio, finalmente, fosse instituído no país.

A Igreja Católica, por sua vez, dá sinais de estar atenta ao desejo de seus fiéis recasados de voltarem a fazer parte de suas atividades religiosas. Em um artigo intitulado "Nova aliança", uma revista semanal de abrangência nacional, apresenta a situação atual da "paróquia dos excluídos", expressão utilizada para denominar os católicos que foram proibidos de exercer sua fé em virtude do divórcio e do recasamento. $\mathrm{O}$ artigo descreve os movimentos existentes em 
diversas regiões do Brasil que, com o apoio da Conferência Nacional dos Bispos do Brasil (CNBB), visam debater o tema e incluir os casais recasados nas atividades pastorais. Destacamos o seguinte fragmento do artigo, que cita as palavras do Padre Jesus Hortal Sánches, reitor da Pontifícia Universidade Católica do Rio de Janeiro e especialista em direito canônico:

\footnotetext{
“A Igreja tem de responder às necessidades do seu tempo. (...) $\mathrm{O}$ fracasso de muitos casamentos é um fato social inegável. A Igreja hoje reconhece a segunda união como um fato" (Revista Isto é, n.1728, p.66-68, 13 de novembro de 2002).
}

Embora seus representantes estejam cientes da realidade atual, na prática a Igreja ainda não permite que os casais separados casem novamente ou recebam os sacramentos. De certa maneira, parece haver um desejo, por parte de alguns membros da Igreja, em contornar a situação, conforme nos mostra mais um fragmento do texto publicado:

\footnotetext{
"Mas, mesmo sem dar o sacramento em cerimônias tradicionais, a Igreja tem abençoado casais de segunda união por meio de suas coordenações diocesanas, comandadas por um colegiado de leigos e padres. Embora a ousadia não tenha acolhimento unânime, alguns padres já dão informalmente o sacramento da eucaristia a casais de segunda união em ocasiões especiais, como aniversário de um dos cônjuges ou missas de Natal" (Revista Isto é, n.1728, p.66-68, 13 de novembro de 2002).
}

$\mathrm{O}$ artigo acima mencionado ressalta a quantidade de recasamentos existentes atualmente no Brasil, mostrando que existem mais de cinco milhões de desquitados ou divorciados que vivem com suas novas famílias em lares reconstituídos.

Na visão de Berger e Kellner (1964), autores do artigo mencionado no item anterior sobre a importância do casamento nas construções do casal, o aumento do número de divórcios, que a primeira vista pode parecer uma argumentação contrária à consideração teórica tecida por eles, na verdade significa o oposto. Os divórcios não ocorrem porque os casamentos tornam-se pouco importantes, mas porque sua importância é tal que os indivíduos não aceitam que suas expectativas relacionadas a esta união sejam frustradas. Acrescentam que a freqüência com que ocorrem os divórcios simplesmente reflete as dificuldades e as demandas imposta a um casal na tarefa de criação e manutenção da vida em comum. Apesar das dificuldades, a maioria dos indivíduos divorciados planeja recasar. 
Tanto no contexto social brasileiro como no americano, o divórcio é visto como um sintoma de instabilidade familiar e um sinônimo de dissolução da família. Ahrons (1999) comenta que esta noção pode ser percebida nos termos utilizados para descrever a família divorciada, que apontam para "lares desfeitos", “desorganização familiar”, etc. As pesquisas, também, focalizam os possíveis problemas criados pelo divórcio, assim como é comum que problemas com drogas, delinqüência e violência sejam associados, nos meios de comunicação, à separação conjugal.

Quanto a noção de ciclo de vida familiar, o divórcio representa uma ruptura na dimensão de longo prazo. De acordo com Carter e McGoldrick (1999), os Estados Unidos têm a taxa mais alta de divórcio, dos países industrializados (entre $50 \%$ e $46 \%$ nos anos 90 ) porém, têm também a taxa mais alta de casamentos ( $90 \%$ primeiro casamento e $70 \%$ recasamento), o que para as autoras reflete a crença americana no casamento e na família, como estrutura de escolha. As altas taxas apresentadas dão lugar a um novo ciclo mencionado pelas autoras, que envolve casamento, divórcio, recasamento e redivórcio. Esta dinâmica acaba por gerar um grande número de famílias vivendo a situação de famílias recasadas.

\section{7}

\section{Recasamento: Reconstrução da Conjugalidade e Reformulação dos Papéis Familiares}

O recasamento, seja em forma de união legalizada, ou como união consensual, é uma das possibilidades pós-divórcio. Certamente não são todos os indivíduos separados que voltam a construir uma relação conjugal estável. Algumas vezes, só um dos membros do casal, geralmente o homem, reconstrói sua vida familiar em torno de um novo vínculo conjugal. A possibilidade de recasamento depende de uma série de fatores, como idade dos envolvidos, local onde vivem e, principalmente, a vontade de recomeçar. As estatísticas, tanto americanas como brasileiras, nos mostram que é significativo o número de recasamentos.

Analisando as recomposições familiares, Segalen (1996) comenta a situação familiar no período pós-divórcio. A autora observa que, embora o divórcio dissocie o casal conjugal e o casal parental, o segundo deve ser mantido 
para gerir as necessidades dos filhos. Fazendo uma análise da situação pósconjugal na França, a autora mostra, através de inquéritos realizados, que a preservação do laço pós-conjugal em prol do interesse dos filhos, parece difícil ou mesmo utópica. Os resultados dos inquéritos falam de um "descomprometimento familiar dos homens", o que é, ao mesmo tempo, contra atacado com o argumento da valorização da relação mãe-filho pela sociedade, "que parece concorrer para expulsar os homens da família desunida". A partir dessas constatações a autora comenta que o número de crianças que vivem em famílias recasadas (chamadas por ela de recompostas) tem aumentado. Entre 1981 e 1986, por exemplo, $48 \%$ das crianças viram um dos pais formar uma nova união e, no caso de $37 \%$ das crianças, ambos os pais recasaram. Segalen constata que além dos problemas levantados pela ausência de enquadramento jurídico ou legal para estas novas famílias, apresenta-se a complexidade fundamental, que é a divisão dos papéis. A autora descreve que, a partir das transformações e banalização das formas de divórcio, à parentalidade biológica vem somar-se a "parentalidade social", que aparece como uma visão mais atual da figura do padrasto e da madrasta.

As palavras utilizadas para descrever essas novas relações familiares, inquéritos e pesquisas mostrando o percentual de transformações, nos remetem, mais uma vez, à questão da clínica. É na clínica que encontramos indivíduos que estão menos preocupados com as estatísticas e com a nomeação sociológica ou jurídica que descreve a situação por eles vivida, mas procuram respostas que apontem para a forma de interação dessa nova família, ou que esclareçam porque as relações estão funcionando desta ou daquela maneira. É a relação entre a clínica e a situação de recasamento que direciona o presente trabalho.

O modelo de família que nasce a partir dos laços de um casamento no qual os cônjuges se uniram pela própria escolha amorosa, que pressupõe igualdade e reciprocidade afetiva, que volta sua atenção para a criação de seus filhos, e que o grupo familiar ocupa o mesmo espaço residencial, é o que estamos chamando de família nuclear ou família conjugal. É a partir deste modelo que desenvolveremos as questões relacionadas ao recasamento, apresentando-o como um desafio para o modelo de família nuclear moderna.

Vimos que a própria noção de um ciclo de vida familiar, dividido em etapas que abrangem períodos de maior ou menor duração, configura a relevância 
conferida à dimensão de longo prazo na construção e manutenção familiar. A separação conjugal apresenta-se como um corte neste trajeto. Há uma quebra na continuidade de um projeto do grupo, seja esse grupo formado apenas pelo casal, tendo como pano de fundo suas respectivas famílias de origem, ou pelo casal e seus filhos. Se a separação apresenta-se como uma ruptura, o que a idéia de recasamento representa para os diferentes membros da família e para o contexto social onde ela está inserida? Será que representa um "conserto", um "remendo" ? Representa o início de uma nova construção? E os membros da família que estão excluídos da nova construção, como se sentem? Como reagem? Como funciona a chamada unidade familiar, agora partida? Desorientados pela nova situação, alguns membros dessas famílias buscam ajuda psicológica. De que forma os terapeutas de família do Rio de Janeiro percebem todas essas questões e como estão lidando com elas na clínica? Estas questões estão subjacentes a todas as etapas do presente trabalho. Através delas buscaremos subsídios que nos permitam compreender e tratar esse novo formato de família, que juntamente com outras configurações familiares contemporâneas, tais como famílias uniparentais, famílias homossexuais, famílias adotivas, interagem com instituições que não prevêem sua existência e buscam ajuda psicoterápica em nossas clínicas.

No próximo capítulo, voltaremos nossa atenção para as especificidades das famílias recasadas, apresentadas nas diversas configurações nas quais elas se constituem. Direcionaremos nossas investigações para os relatos de experiências clínicas de terapeutas de família e para pesquisas voltadas para o tema. 


\section{2}

\section{O Recasamento}

"Casar novamente representa o triunfo da esperança sobre a experiência".

(Samuel Johnson ,s.d., citado em Visher e Visher, 1988)

\section{1}

\section{Famílias Recasadas: O Seu Surgimento na Clínica}

Recasamentos e famílias recasadas sempre representaram uma parcela substancial dos casamentos e famílias nos Estados Unidos e em outros países ocidentais, entretanto, até a década de 70, os pesquisadores não pareciam demonstrar um grande interesse pelo tema. A partir de então, segundo Coleman, Ganong e Fine (2000), quando a maioria dos recasamentos passou a ser precedida pelo divórcio e não mais pela viuvez, o fenômeno começou a ocupar um espaço social que era difícil de ser ignorado. Os autores observam que, enquanto o recasamento precedido pela viuvez buscava reconstituir a família nuclear, o precedido pelo divórcio acrescentava figuras parentais à família, através da presença de padrastos e madrastas, embora os filhos continuassem a manter contato com seus pais biológicos. As complicações surgidas a partir das novas uniões, assim como os novos padrões de interação entre os membros dessas famílias, criaram uma "explosão de interesse" pelo tema. Nos anos 80, pesquisadores e terapeutas focalizaram suas atenções para as novas relações familiares que estavam sendo construídas a partir do recasamento.

Na clínica, o aumento da presença de famílias recasadas após o divórcio, também despertou a atenção dos terapeutas. Sager e colaboradores (1983), em um trabalho que tornou-se referência para estudos sobre o recasamento, apresentam as razões que os levaram a criar um serviço especializado para famílias recasadas, no Estados Unidos, em 1976, o “Jewish Family Service of New York City". Observaram, através do aumento do número de famílias recasadas em suas clínicas, que muitas delas não estavam "funcionando bem”. Reconheceram que 
suas abordagens terapêuticas, baseadas na estrutura, propósitos, papéis, mitos e valores da família nuclear, eram inadequadas para o tratamento e estudo das famílias recasadas. Começaram, então, a avaliar uma série de questões: Quem são os envolvidos nesses novos sistemas familiares? Qual é a estrutura da família recasada? De que forma as famílias recasadas diferem das famílias nucleares intactas? Quais são as dimensões do sistema de uma família recasada? Como esses sistemas operam, tanto para o bem estar da unidade familiar como para o do indivíduo? Como as histórias vividas pelos membros das famílias recasadas influenciam seus sentimentos e comportamentos? Como podemos pensar caminhos que nos permitam trabalhar, de maneira mais eficiente, em favor do casal recasado, dos filhos, dos ex-cônjuges, e das constelações familiares de ambos os pais biológicos? Como podemos prevenir disfunções nas famílias recasadas, e os efeitos adversos, de curto e longo prazo, sobre os filhos? Existem potenciais positivos que possam propiciar valores saudáveis, amadurecimento e realizações para as crianças e adultos em situação de recasamento? Se existem, o que os terapeutas podem fazer para que esses potenciais sejam desencadeados e realizados?

Como terapeutas, trabalhando em espaço clínico, o objetivo primeiro dos autores era compreender a estrutura, as necessidades e as dinâmicas, não apenas das famílias recasadas, mas dos ex-cônjuges, para tornarem mais eficientes suas habilidades terapêuticas. Ao mesmo tempo, esperavam desenvolver uma teoria que desse suporte às ações terapêuticas e aos esforços preventivos. Os autores consideraram seu trabalho como o começo desse processo, e comentaram que muito ainda teria que ser feito para que, as relações criadas a partir do recasamento perdessem a "mitologia negativa" a seu respeito.

Como base teórica para suporte de seu trabalho clínico, mencionam uma abordagem de base sistêmica, mas admitem que lançaram mão de outras abordagens de terapia familiar que conseguissem integrar os sistemas biológico, intrapsíquico, interpessoal, familiar, institucional e social para a compreensão da complexa rede de relações formada por famílias recasadas.

Emily e John Visher, autores de vários livros e artigos sobre recasamento, fundaram a "Stepfamily Association of America" , uma associação voltada para pesquisas e para o tratamento de famílias recasadas. Em seu livro "Old loyalties, new ties" (1988) (Velhas lealdades, novos laços), afirmam que um maior 
conhecimento terapêutico sobre as relações do recasamento, deverá contribuir para que a sociedade tenha uma visão das famílias recasadas como unidades familiares possíveis e viáveis, de estrutura complexa, criadas a partir da integração de antigas lealdades associadas a novos laços, e não cópias imperfeitas da família nuclear. Os Visher também utilizam uma abordagem sistêmica, lançando mão de técnicas como o genograma, para representar as relações familiares.

Autores do livro "Stepfamilies" (1998), James Bray e John Kelly também passaram a desenvolver pesquisas sobre famílias recasadas a partir de um aumento da presença dessas famílias em suas clínicas. Bray criou o "Developmental Issues in Stepfamilies" (DIS) um projeto de pesquisa que mais tarde recebeu subsídios de órgãos públicos, da área de saúde dos EUA (National Institute of Health e National Institute of Child Health and Human Development), para desenvolver e avaliar um programa de tratamento que auxiliasse as famílias recasadas a lidarem com suas dificuldades.

Gladis Brun, terapeuta de família, brasileira, e uma das fundadoras do Instituto de Terapia de Família do Rio de Janeiro - (ITF-RJ), em 1987, ressalta que seu livro "Pais, Filhos e Cia. Ilimitada" (1999) faz parte de um projeto maior dedicado ao estudo das organizações familiares do final do século passado. A idéia de Brun, que coincide com as dos autores acima mencionados, é que os estudos e as discussões sobre as novas formas de família contribuam para a prevenção na área de saúde mental.

Ao apresentar alguns dos autores que estudam o recasamento e trabalham com famílias recasadas, quisemos mostrar, mais uma vez, que os estudos sobre o tema surgiram de uma demanda clínica, que foi crescendo com o passar do tempo. Um outro fato que chamou nossa atenção, foi que, mesmo autores que escreveram em épocas diferentes, demonstraram uma preocupação em descrever, de uma forma que podemos chamar de didática, as diferenças entre famílias nucleares e famílias recasadas, mostrando que a comparação entre elas, com a intenção de ter a família nuclear como modelo, é inadequada, pois apresentam estruturas diversas. Além da diferença na estrutura familiar, os autores, geralmente, enfatizam que, embora os papéis de pai, mãe, filhos, avós, etc, desempenhados por membros de famílias nucleares, estejam claramente definidos nas sociedades ocidentais, os papéis criados a partir do recasamento, como madrasta, enteados, padrasto ou pais do padrasto, ainda carecem de uma definição mais abrangente. 
As pesquisas iniciais mostravam uma grande preocupação em descrever as dificuldades enfrentadas pelas famílias recasadas. Outras prendiam-se a transcrições dos diálogos entre famílias ou membros das famílias e terapeutas. Pesquisas mais recentes, contudo, preocupam-se com as diferenças estruturais entre famílias recasadas e nucleares, não como uma comparação, mas para que a compreensão das diferenças possibilite uma melhor interação entre os diversos membros da família e a utilização mais eficiente de recursos terapêuticos.

Estudiosos do recasamento (Sager e colaboradores, 1983; Visher e Visher, 1988; McGoldrick e Carter, 1999; Coleman, Ganog e Fine, 2000) são unânimes em afirmar que muitas das dificuldades enfrentadas pelos membros das famílias recasadas podem ser atribuídas ao fato de a sociedade em geral, as próprias famílias recasadas e, até mesmo, os terapeutas de família, utilizarem a família nuclear intacta como um modelo de família a ser seguido ou alcançado.

Segundo Irene Levin (1997), professora da Escola de Serviço e Pesquisas Sociais da Universidade de Oslo, Noruega, tratando-se de formatos de família, fica evidente a existência de uma hierarquia na qual a família nuclear ocupa uma posição privilegiada. Famílias recasadas, uniparentais e com outras configurações são vistas como "alternativas deficientes". Para ilustrar a posição ocupada pelo modelo de família nuclear na cultura ocidental contemporânea, a autora cita o trabalho de Dorothy Smith (1993). Smith introduz o modelo denominado de SNAF (Standard North American Family), como o formato de família ao qual todos os outros serão direta ou indiretamente comparados. O SNAF é considerado um código ideológico que, em analogia a um código genético, reproduz suas formas características e normas através da linguagem. Como exemplo dessa reprodução, Levin (1997) menciona a expressão "working mothers", utilizada em inglês para designar as mães que trabalham fora. A autora comenta que o termo "working fathers" não é usado numa descrição semelhante em relação aos homens, pois a noção de pais que trabalham reflete o código ideológico, não necessitando de qualquer explicação.

Em um trabalho que tem como objetivo confrontar a parcialidade percebida em relação à família nuclear em pesquisas sobre famílias recasadas, Susan Gamache (1997) afirma que as pressuposições em relação ao modelo de família nuclear permeiam nossa visão da família recasada. Acrescenta que, os próprios pesquisadores estão inseridos numa cultura que coloca a família nuclear 
na posição exemplar com a qual todas as demais configurações familiares serão comparadas e, como modelo privilegiado pela sociedade, domina valores e crenças. À medida que a família recasada permanece não institucionalizada, não há estruturas sociais apropriadas para validá-la e apoiá-la, fazendo com que a família nuclear continue a ser o modelo cultural padrão.

Segundo Gamache (1997) pesquisas sobre o recasamento buscam respostas para perguntas sobre as relações existentes entre enteados, padrastos e madrastas através da abordagem de comparação por déficit (deficit-comparison approach), que compara essas relações àquelas de famílias nucleares. Evidentemente, partindo desse tipo de abordagem, a família recasada aparece como deficiente. A autora observa que, embora muitos estudiosos já tenham apontado para a necessidade de mudança de abordagem nas pesquisas, este fato parece não ter tido qualquer influência nas suposições fundamentais correntes que padrastos e madrastas devem ter como padrão o modelo parental, tal como definido pelo modelo de família nuclear. Embora já tenham sido feitas criticas e recomendações para que as pesquisas voltem seus focos para os tipos de relações funcionais na situação de recasamento, ao invés de privilegiar as comparações entre os dois formatos de família, tais sugestões parecem não ter tido um impacto suficientemente forte para transformar as antigas suposições.

A compreensão da dinâmica familiar no recasamento requer, em primeiro lugar, uma revisão dos papéis tradicionalmente exercidos pelos membros de uma família. No modelo tradicional, o exercício de algumas funções familiares já foi socialmente selecionado por gênero. A mulher, por exemplo, é responsável pelo cuidado com os filhos, pela organização doméstica e pelo relacionamento emocional do sistema familiar. Nas famílias recasadas, entretanto, a seleção de papéis determinada por gênero deve dar lugar à relação histórica entre pai/mãe biológico e filhos (McGoldrick e Carter, 1999).

Em um estudo comparativo entre casais de primeiro casamento e casais recasados, do Rio de Janeiro, Féres-Carneiro (1987) observou que, embora os sujeitos dos dois grupos entrevistados exercessem as funções familiares conforme os papéis culturalmente atribuídos ao homem e à mulher, no grupo de recasados esta divisão foi vista de forma menos rígida do que no de primeiro casamento. Segundo a autora, contudo, verificou-se que as tarefas domésticas eram atribuídas à mulher, mesmo que esta trabalhasse fora. Este dado aponta, mais uma vez, para 
a prevalência do modelo de família nuclear, que é levado para um novo casamento, sem que as diferenças da nova estrutura familiar sejam levadas em conta.

As pesquisas mais recentes sobre o tema nos levam a concluir que o reconhecimento da complexidade estrutural e da diversidade das famílias recasadas, assim como o conhecimento das especificidades que as diferenciam de famílias de primeiro casamento, são elementos fundamentais para a compreensão e tratamento dessas famílias. Embora cada família recasada só possa ser totalmente compreendida no contexto de sua história e de sua família ou famílias antecedentes, faremos uma análise das especificidades principais que a diferenciam da família de primeiro casamento.

\section{2}

\section{Famílias Recasadas: Características e Especificidades}

Estudiosos do recasamento utilizam parâmetros ou categorias diversas para caracterizar as especificidades da família recasada, em relação à família nuclear. Sager e colaboradores (1983), por exemplo, baseiam-se em sete categorias para diferenciar os dois formatos de família: 1. estrutura do sistema; 2. propósito do sistema; 3.tarefas do sistema; 4. natureza dos vínculos do sistema; 5. fatores que influenciam os adultos no sistema; 6. fatores que influenciam as crianças no sistema; 7. forças que atingem o sistema. Zareena Genovese e Thomas Genovese (1997) analisam as características das famílias recasadas, apresentando áreas potencialmente conflituosas na interação familiar. Outros autores, como E. Visher, J. Visher (1988) e Patricia Kelley (1996), também utilizam algumas características para apresentar as diferenças essenciais entre os dois formatos de famílias. Todos os autores concordam, entretanto, que a estrutura é o ponto de partida para tal diferenciação.

A partir de uma revisão da literatura, escolhemos seis categorias que nos ajudarão a analisar as características, o funcionamento e as relações entre os membros de uma família que tem como ponto de origem o recasamento. Utilizamos as seguintes categorias: 1. estrutura familiar; 2. desempenho dos papéis familiares; 3. conflitos de lealdade; 4. fronteiras; 5. expectativas; 6. responsabilidades parentais. 


\subsection{1}

\section{Estrutura: Como é Constituida a Família Recasada}

A família nuclear é constituída por dois adultos e um ou mais filhos, todos biologicamente relacionados aos pais. A família recasada também é constituída por dois adultos, mas os filhos trazidos para esta nova família, são relacionados biologicamente a apenas um dos membros do casal.

Enquanto na família nuclear as tarefas parentais são exclusivas do casal, na recasada, na maioria das vezes, as tarefas de cuidados com os filhos são divididas por pelo menos três adultos: os pais biológicos e um padrasto ou madrasta. $\mathrm{O}$ número de adultos envolvidos pode variar, se ambos os membros do casal tiverem sido casados antes, se os filhos forem de diferentes uniões anteriores, ou se ambos os pais biológicos recasaram.

No primeiro casamento a díade conjugal antecede a díade parental. Em uniões subsequentes a relação pai-filho(a) ou mãe-filho(a) precede a relação conjugal. No período pós-separação, que antecede ao recasamento, o vínculo entre o pai ou a mãe separado(a) e os filhos que moram com ele(a), torna-se mais estreito, o que dificulta a aceitação, por parte dos filhos, de um novo membro na família.

Todos os membros da família nuclear pertencem a apenas um sistema familiar. Na família recasada alguns dos membros pertencem a mais de um. Levando-se em conta o fato de haver filhos de mais de uma união anterior, vários sistemas familiares podem estar representados na família.

Segundo Sager (1983), as fronteiras biológicas, geográficas, legais e o pertencimento de seus membros são claramente definidos na família de primeiro casamento. O mesmo não acontece nas famílias recasadas, onde alguns filhos/ enteados são vistos como hóspedes periódicos.

E.Visher, J.Visher e colaboradores (1996) observam que, ao contrário das famílias nucleares, onde o pertencimento é definido por laços sangüíneos, legais e espaciais e caracterizado por fronteiras explícitas, a estrutura da família recasada é menos definida, menos clara. $\mathrm{O}$ fato de os filhos pertencerem, simultaneamente, a dois lares diferentes, por exemplo, aumenta a possibilidade de surgimento de sentimentos de ambigüidade em relação às fronteiras, o que freqüentemente resulta em conflitos de lealdade e sentimento de culpa. 
Os membros da família extensa de cada cônjuge são vistos como parentes por todos os filhos na família nuclear. Na família recasada, porém, as relações de parentesco de um filho podem ser diferentes das de seus irmãos.

Existe um vínculo legal simétrico entre os pais biológicos e seus filhos. Por terem os mesmos pais, os irmãos também possuem o mesmo vínculo entre eles. Todos os membros da família nuclear são vinculados legalmente entre si. Nas famílias recasadas não existe esta simetria. Enteados, padrastos, madrastas e irmãos, que na realidade não são irmãos, não possuem qualquer vínculo legal. Os vínculos poderão ser afetivos, se os membros da família assim o desejarem.

\subsection{2}

\section{O Desempenho dos Papéis Familiares}

Os papéis ou funções na família recasada não são claramente definidos. Embora as funções de pai, mãe, filhos e irmãos sejam socialmente bastante claras, a sociedade não possui regras claras quanto às funções de padrastos, madrastas e enteados. Sem um vínculo biológico ou legal a autoridade de padrastos e madrastas, por exemplo, não possui qualquer respaldo (Kelley, P., 1996).

Em uma análise comparativa entre o primeiro casamento e o recasamento, Genovese e Genovese (1997) afirmam que o período que antecede à chegada dos filhos, em famílias de primeiro casamento, permite ao casal um tempo de adaptação à vida em comum. Na opinião dos autores, o casal tem a possibilidade de aprender a funcionar como uma unidade. Quando nasce o primeiro filho, os membros do casal assumem papéis parentais. Os casais recasados, entretanto, não dispõem de tempo ou privacidade suficientes para assimilar e assumir as funções conjugais e parentais.

A nomeação das novas relações familiares, é um fator de discussão entre terapeutas e pesquisadores do recasamento. Embora pesquisadores de língua inglesa mencionem a inadequação na nomeação das relações no recasamento, em português tais relações não são, sequer, nomeadas. Os filhos de relações anteriores dos membros do casal moram na mesma família e agem como se fossem irmãos, mas não o são. Em inglês são "stepsiblings" (irmãos por recasamento), assim como os pais do padrasto ou da madrasta são os "stepgrandparents" (avós pelo 
recasamento). Concordamos com a opinião dos estudiosos que acreditam que a falta de nomeação dificulta o reconhecimento dos papéis familiares.

Em um estudo onde discute a falta de políticas públicas específicas que incluam as famílias recasadas na Inglaterra, De'ath (1997) observa que a palavra inglesa "stepfamily" só foi incluída no "The Concise Oxford Dictionary" em julho de 1995, depois de uma representação feita pela "National Stepfamily Association".

Jan Trost, professora de sociologia da Universidade de Uppsala, na Suécia, em sua pesquisa sobre famílias recasadas de diferentes configurações, observa que viu o termo "stepfamilies" publicado pela primeira vez em 1964. Até então não havia nomeação, na literatura especializada para este formato de família, apenas para as relações criadas entre os adultos (padrasto e madrasta) e as crianças ou filhos (enteados), exatamente como acontece ainda hoje no Brasil. Segundo a autora, a falta de termos que definam uma relação denota a falta de expectativa social que esta relação exista. Menciona, ainda, outros usos da linguagem que descrevem os pais biológicos como verdadeiros ou naturais e identificam a família nuclear como tradicional, real ou normal, deixando implícita a mensagem de que padrastos e madrastas não são verdadeiros ou naturais e que outros formatos de família são não tradicionais, irreais ou anormais (Trost, 1997)

McGoldrick e Carter (1999) consideram os novos papéis e as novas relações criadas pelo recasamento potencialmente conflituosas, complexas e ambíguas. Segundo as autoras, a complexidade é refletida pela falta de uma nomeação positiva para as novas relações, visto que consideram as palavras utilizadas para descrevê-las impregnadas de sentidos negativos. Comentam, ainda, que a posição dos filhos na família nuclear pode ser modificada pela nova estrutura do recasamento. Posições como a de filho mais novo, filho mais velho, único(a) filho(a), podem passar por mudanças abruptas com a formação da nova família.

A divisão tradicional de papéis, feita a partir de diferenças de gênero, também pode gerar conflitos em famílias recasadas. Em sua discussão sobre o tema, McGoldrick e Carter (1999) afirmam que a formação da família recasada requer uma revisão na divisão de papéis. As autoras sugerem que a divisão seja feita a partir do que chamaram de relação histórica entre o adulto e os filhos. Ou seja, ao invés de funções masculinas e funções femininas, passam a existir 
funções de adultos que responsabilizam-se por seus filhos biológicos, embora haja uma convivência familiar entre todos os membros da família.

Segundo Levin (1997) muitas pesquisas atribuem às questões de gênero as dificuldades de relacionamento e comunicação entre os membros de famílias recasaddas. Tal atribuição, no entanto, é feita sem qualquer explicação sobre as dinâmicas e processos envolvidos na geração das dificuldades. Através de um estudo desenvolvido na Noruega para a avaliação da realidade social de famílias recasadas e do desempenho dos papéis de madrasta, padrasto e enteados, a autora apresenta dados que nos ajudam a refletir sobre o tema. Depois de exemplificar como as famílias recasadas podem ter padrões de comportamentos diferentes, e que o papel de madrasta/padrasto pode diferir a partir da percepção que ela/ele tenha de sua nova vida familiar, Levin faz uma análise da escolha de estilo de vida de três casais da amostra, tomando como base a questão de gênero. Conclui que as funções das mulheres são muito semelhantes, sejam elas mães ou madrastas. $\mathrm{Na}$ realidade elas são responsáveis pelas crianças e pela casa. Os requisitos geralmente associados ao papel de madrasta não exigem que ela cumpra tais tarefas, pelo contrário, este papel carrega a expectativa de uma certa distância entre os filhos e o papel de mulher do parceiro. A descrição do papel feminino, porém, é exatamente oposta. Está criado, então, um dilema entre os dois papéis. A autora comenta sobre a impossibilidade de se estar ao mesmo tempo afastada, pela função de madrasta, e próxima, pela função de "mulher da casa". O resultado deste dilema é que o papel feminino acaba por "conquistar" o papel de madrasta e torna-se decisivo quanto ao que deve ou não ser feito. À medida que o papel feminino e o papel de mãe se sobrepõem, o fato de ser mulher torna-se mais relevante para o exercício do papel de madrasta do que o de ser apenas a parceira do pai. Para Levin, neste caso, o gênero é mais forte do que a consangüinidade. $\mathrm{O}$ mesmo dilema não apareceu no resultado de avaliação dos homens, pois tanto o papel de padrasto quanto o papel masculino, exercidos pelos parceiros, sugerem uma certa distância. Embora para os homens o gênero também seja decisivo quanto ao que fazer, não há dilemas entre os dois papéis.

Em um estudo com dois grupos de adolescentes brasileiros, entre 12 e 17 anos, que vivem em famílias de primeiro casamento e famílias recasadas, Wagner e Sarriera (1999) afirmam que, 
"apesar das claras modificações que se estabelecem no relacionamento com os progenitores nas famílias recasadas, é importante observar que aquelas funções que culturalmente estão associados ao gênero feminino ou masculino, se mantêm, independentemente da configuração familiar" (p.26).

Os autores comentam ainda que, mesmo com as transformações ocorridas em relação à mulher e sua inserção no mercado de trabalho e ao conceito de família, permanece a noção de atribuição da manutenção econômica da família relacionada ao gênero masculino e a de cuidado com o lar relacionada ao gênero feminino. Concluem que "valores, atitudes e funções ditas novas e modernas, estão convivendo com concepções arcaicas nos núcleos familiares de hoje em dia "(p.26).

Ao abordar o tema, sob a ótica da sociologia da família, Segalen (1996) fala da "abundância de pais" no que chama de famílias recompostas. A autora afirma que os papéis sociais ligados às posições parentais ficam subitamente repartidos por várias pessoas. Discorrendo sobre o processo de recomposição familiar, a autora comenta:

“A noção de família é dissociada da de co-residência; será antes uma abundância e não uma falta de parentes que estas crianças conhecem, com o padrasto, a madrasta, os meios-irmãos e os falsos irmãos, seis ou oito casais de avós, etc" (Segalen, 1996, p.64).

\subsection{3}

\section{Os Conflitos de Lealdade Gerados pelas Novas Relações}

Pesquisadores e terapeutas que trabalham com famílias formadas pelo recasamento (Sager e colaboradores, 1983; Visher e Visher, 1988; Kelley, 1996; Genovese e Genovese, 1997; Carter e McGoldrick, 1999; Wagner e Sarriera, 1999), afirmam que os conflitos de lealdade perpassam os membros da família recasada em diferentes momentos de seu convívio. A percepção dos filhos, por exemplo, de que sua participação numa nova família que exclui membros de sua família biológica e, principalmente, os sentimentos positivos em relação à nova família, desencadeiam sentimentos ambíguos, que estamos chamando de conflitos de lealdade. Estes conflitos atingem outros membros da família recasada, como veremos a seguir. 
Kelley, P. (1996) observa que o sentimento de lealdade dos filhos em relação aos pais biológicos, por exemplo, é considerado "quase universal". Em seu livro "Old loyalties, new ties", Visher e Visher (1988) discorrem extensamente sobre lealdades e conflitos na família recasada. Os autores afirmam que sentimentos como culpa, ciúmes, raiva e depressão, gerados por conflitos de lealdade interpessoais, sempre surgem entre os membros da família recasada.

$\mathrm{Na}$ família nuclear intacta o compromisso fundamental de lealdade diz respeito à manutenção do próprio grupo (Boszomenyi-Nagy e Sparks, 1984). Os membros da família recasada trazem para o novo grupo familiar, por um lado, o sentimento de lealdade relacionado ao passado e, por outro, muito pouca lealdade em relação aos novos membros da família. Tais sentimentos acabam por gerar situações que Visher e Visher (1988) descrevem como triangulações familiares. As triangulações são criadas pelos conflitos de lealdade que acabam por dividir o grupo em "times" ou "lados".

Visher e Visher (1988) demonstram como se dão as principais triangulações e conflitos entre os membros da família recasada. Os autores fazem uma divisão entre os conflitos de lealdade que afligem os adultos e os que afligem as crianças (ou os filhos). Segundo os autores, os dois principais conflitos do cônjuge recasado dizem respeito ao sentimento de divisão entre seu novo par e seus filhos e ao sentimento de divisão entre seus filhos biológicos e os enteados. Sager e colaboradores (1983) consideram o conflito interno dos pais entre o amor pelos próprios filhos e o amor pelo novo cônjuge a maior fonte de tensão nas famílias recasadas. Aqui, o sentimento de culpa pode afligir os pais biológicos, que algumas vezes sentem como se estivessem traindo suas relações com os filhos.

O vínculo entre pais e filhos é, freqüentemente, estreitado no período pósseparação. A prática clínica nos mostra que muitas vezes, após a separação, os filhos pequenos saem de seus quartos e passam a dormir na cama da mãe ou do pai. Quando os pais recasam, os filhos e o novo cônjuge podem entrar numa disputa pelo afeto ou pela atenção do pai/mãe ou do parceiro/a.

O segundo ponto mencionado, quando ambos os parceiros têm filhos, é o conflito entre os sentimentos em relação aos próprios filhos e em relação aos enteados. Gostar mais versus gostar menos, cuidar de uns quando deveria estar cuidando de outros, exercer tarefas parentais para filhos de outros enquanto os 
próprios filhos moram em outra casa, são algumas variações sobre o tema, que também podem gerar sentimentos de culpa e raiva.

$\mathrm{O}$ adulto que recasa pode ter o ex-cônjuge como uma outra fonte de conflito de lealdade. O tempo necessário para que o processo de separação conjugal se complete, varia de pessoa para pessoa. Os ex-cônjuges passam por várias etapas, que incluem desde a decisão individual de separar-se até a separação emocional de ambos os parceiros. Muitas vezes o recasamento acontece antes que tal processo tenha se completado. A intimidade com o ex-cônjuge pode gerar conflitos tanto ao casal recasado quanto à nova relação que os ex-cônjuges tentam criar, agora baseada somente no vínculo de co-parentalidade (Visher e Visher, 1988; Ahrons, 1999; McGoldrick e Carter, 1999).

A família extensa também aparece como geradora de conflitos de lealdade. Os avós podem ter dificuldades em aceitar uma nova nora ou genro, que será madrasta ou padrasto de seus netos. Podem, ainda, tentar manter uma relação muito próxima com a mãe ou o pai biológico de seus netos, fazendo com que o novo cônjuge sinta-se excluído da família. O mesmo pode acontecer com tios, tias, cunhados e primos.

Os filhos de pais recasados também sofrem com os conflitos de lealdade. $\mathrm{O}$ principal deles diz respeito à relação com seus pais biológicos. O recasamento de um dos dois ou de ambos faz com que esses conflitos sejam exacerbados. Muitas vezes os sentimentos são desencadeados por reações dos próprios pais, que buscam cumplicidade de sentimentos nos filhos. Os filhos pequenos, por sua dependência aos pais, são mais vulneráveis a tais conflitos e necessitam da ajuda dos adultos para sentirem-se confortáveis com a nova situação. Uma outra situação potencialmente conflituosa para os filhos diz respeito a relação pai/padrasto ou mãe/madrasta. Mais uma vez o sentimento de culpa por gostar do padrasto ou da madrasta pode aflorar e disparar reações inesperadas, que geram situações de conflito familiar. (Sager at al., 1983; Visher e Visher, 1988; Kelley .P, 1996). 


\title{
2.2.4
}

\section{As Fronteiras: O Processo de Inclusão e Exclusão Familiar}

\begin{abstract}
"Antes de sermos nós mesmos, somos o filho ou a filha de Fulano ou Beltrano; nascemos numa família, e antes que possamos ter uma existência social própria, é por um nome de família que se nos referem. As primeiras palavras que qualquer criança aprende - os tão significativos "papá" e "mamã " - são as que designam o seu pai e a sua mãe, logo a seguir, os demais vocábulos do parentesco ... Assim o mundo se reparte entre os Seus e os Outros “(Zonabend, 1986, p.14).
\end{abstract}

A citação acima nos transmite a idéia de pertencimento, de inclusão na família de origem. Antes de termos uma identidade própria, somos reconhecidos por pertencermos a uma família. Por outro lado, deixa clara uma divisão quando afirma que "o mundo se reparte entre os Seus e os Outros".

Quando pensamos no processo de inclusão e exclusão familiar, tanto em famílias nucleares como em famílias recasadas, estamos pensando no que os teóricos de família de orientação sistêmica chamam de fronteiras, conceito elaborado especificamente na teoria estrutural (cap. 3). Na opinião de Sager (1983) o modo como as famílias respondem às celebrações e cerimônias proporciona, aos estudiosos do tema, uma oportunidade única de observação das fronteiras familiares. Segundo o autor o termo fronteira refere-se aos fatores que contribuem para o senso de identidade familiar. É o que diferencia os membros do grupo dos outros. Em outras palavras, a delimitação das fronteiras torna-se o fator de inclusão ou exclusão familiar. Sager refere-se à descrição de fronteiras de Walker e Messinger (1979), que lembram que elas podem ser objetivas, como as paredes ou muros de uma residência que nos separa de nossos vizinhos, ou subjetivas, tais como as fronteiras que definem o grau de intimidade e proximidade física que os membros da família têm uns com os outros.

Salvador Minuchin (1980), um dos pioneiros entre os terapeutas de família, mostra, clara e sucintamente, a função das fronteiras dentro de um sistema familiar: “... são as regras que definem quem participa e como" (p.58). Embora o autor refira-se, nesta descrição, a fronteiras entre os membros da família nuclear, que formam subsistemas que interagem dentro do sistema familiar (cap.3), o conceito pode ser estendido a outras interações familiares, sejam elas com as famílias de origem dos membros do casal, ou as novas relações familiares criadas pelo recasamento. 
Ao analisarmos as fronteiras da família recasada, tomamos como ponto de partida o casamento anterior e a separação conjugal, capítulos de grande relevância que precedem a história do recasamento. Novas uniões implicam na formação de novas famílias, com a inclusão ou exclusão de parentes mais ou menos próximos, provindos de casamentos anteriores.

Ao decidirem compartilhar a vida um com o outro, os parceiros iniciam a construção de um mundo comum (Veiga-da-Silva, 1997). Segundo o autor, a conjugalidade vai sendo construída ao longo do tempo, através da aquisição de bens materiais e imateriais. Projetos e prazeres tornam-se comuns. Os cônjuges começam a usar os pronomes nós e nosso(a) quando referem-se a seus filhos, seus parentes, seus amigos e seus bens. Existe um domicílio comum, um sobrenome comum, enfim, uma unidade familiar onde, supostamente, todos estão incluídos.

O processo de inclusão que ocorre no casamento é invertido na separação conjugal. Ao decidirem pela separação, os membros do casal dão início a uma série de exclusões ou desconstruções. O primeiro passo, na maioria das vezes, é a saída de um ou de ambos os cônjuges do domicílio familiar. A seguir são excluídos objetos, nomes em contas bancárias conjuntas e em outros documentos que os confirmem como casados. No vocabulário do casal é incluído o prefixo "ex-“, que será colocado antes de expressões como "minha sogra", "meu sogro" ou "meu cunhado", indicando que existiu uma relação familiar anterior.

Ao contrário do que geralmente acontece no primeiro casamento, quando pode ocorrer um envolvimento por parte das famílias de origem na preparação que antecede a união do casal, o recasamento, na grande maioria das vezes, vai "acontecendo". A construção objetiva de um domicílio conjugal não é mais prioritária ou necessária, visto que pelo menos um dos parceiros já tem a própria casa. Objetos pessoais, parentes e amigos são incluídos ou excluídos da rotina da nova família, de acordo com as necessidades, com o espaço ou com o possível mal-estar gerado por lembranças do passado (Ahrons, 1999; Carter e McGoldrick, 1999).

Em uma pesquisa clínica sobre famílias recasadas, Sager (1983) relata que muitas famílias ou membros de famílias recasadas procuram ajuda psicoterápica por conflitos desencadeados em virtude de cerimônias e celebrações onde não foram incluídos ou onde acharam que alguém não deveria estar presente. 
O que podemos observar, não apenas através da prática clínica, mas através do próprio convívio social, é que no Brasil não é muito comum a existência de rituais ou celebrações que incluam as famílias dos cônjuges ou, até, que marquem o início de um recasamento.

Brun (1999) afirma que, em nossa cultura, os rituais "marcam para um público mais amplo ‘quem é quem' no grupo familiar (p.68)”. Segundo a autora, é através dos rituais, das cerimônias e das celebrações que são revelados os laços que unem os diferentes membros da família. É, também, nas cerimônias e celebrações importantes que o processo de inclusão e exclusão familiar fica mais evidente.

A ambigüidade das fronteiras é uma questão amplamente discutida por Genovese e Genovese (1997) em seu estudo sobre as famílias recasadas. Segundo os autores, esta ambigüidade é fruto da incerteza em relação a quem é considerado membro da família ou não, e que funções devem desempenhar na nova estrutura familiar. Admitem que a solução torna-se problemática, visto que a reorganização de funções e papéis é dificultada pelo fato de que a ausência física de familiares não implica, necessariamente, em sua ausência psicológica. Exemplificam com os resultados de pesquisas sobre o tema (Pasley, 1987), que apontam para o local de residência como o fator determinante na ambigüidade de fronteiras. Na pesquisa 272 casais recasados identificaram, separadamente, os membros de sua família. A discordância de respostas em relação a um dos filhos, aponta para a existência de uma situação ambígua. Verificou-se que quando o(a) filho(a) do marido morava com a mãe biológica, ele(a) não era considerado um membro da família recasada por muitas das esposas e, até mesmo, por alguns pais biológicos.

Em outra pesquisa americana de âmbito nacional envolvendo 1747 residências, Furstenberg (1987) concluiu que, freqüentemente, havia discordância entre pais e filhos, no que dizia respeito a inclusão dos membros das famílias recasadas no grupo familiar. Enquanto apenas $1 \%$ dos pais biológicos deixaram de mencionar seus filhos, $15 \%$ daqueles que tinham enteados morando na mesma casa não os listaram como membros da família. Em relação aos pais biológicos, $7 \%$ dos filhos não mencionaram a mãe e $9 \%$ não mencionaram o pai. Em contrapartida, $31 \%$ dos enteados deixaram de mencionar madrastas ou padrastos residentes. Foi constatado, mais tarde, que essas opiniões permaneceram 
inalteradas ao longo do tempo. A despeito dos resultados acima mencionados e a existência de uma certa ambigüidade a respeito do pertencimento dos membros da família recasada, foi verificado um sentimento positivo por parte de pais e filhos em relação à qualidade da vida familiar.

Kelley, P., (1996) observa que, a rotina de visitas ao pai ou mãe não residente que é criada a partir da separação conjugal, pode gerar nos filhos a sensação de que não pertencem a, pelo menos, um dos lados de sua família. Segundo a autora, a disposição da família recasada de possuir um espaço determinado para os filhos não residentes, pode promover o visitante à condição de residente ocasional e fortalecer a sensação de pertencimento. Como a nova família ainda não construiu uma história conjunta, a autora menciona a importância da criação de novas tradições familiares, como festas e reuniões familiares, férias conjuntas em determinadas épocas do ano, enfim, eventos que envolvam membros residentes e não residentes, para auxiliar a todos no processo de integração e desenvolvimento familiar. Na realidade, a família necessita criar rituais próprios, para auxiliar os seus membros na delimitação de fronteiras.

\subsection{5}

\section{Expectativas}

Em pesquisa anterior sobre conflitos conjugais (Travis, 1997) constatamos que as expectativas explícitas e não explícitas que os parceiros possuem a respeito do cônjuge e da própria relação conjugal, estavam subjacentes aos diferentes temas de conflitos analisados. No recasamento tais expectativas são acrescidas das expectativas que os filhos, a família extensa e os próprios parceiros têm acerca das novas relações e das funções familiares que deverão ser desempenhadas por todos os membros do grupo.

J. Bray e J. Kelly (1998) concluíram que, até mesmo os sujeitos mais realistas e esclarecidos de sua pesquisa clínica sobre famílias recasadas, mantinham expectativas irrealistas acerca da construção e manutenção das novas relações familiares. Os autores afirmam que, embora os temas comumente relacionados a conflitos familiares como discordância sobre finanças, filhos, enteados e ex-cônjuges sejam realmente considerados motivos de discórdia, o fator que mais dificulta a adaptação à nova vida familiar e a resolução dos 
problemas cotidianos é o fato de não serem esperados. Os autores admitem que os conflitos podem ter "passado pela cabeça dos envolvidos, mas não pelo coração" (p.111). Observam que ter esperança é um sentimento fundamental para o ser humano e que expectativas nada mais são do que uma forma de esperança. Acrescentam que novos começos inspiram esperanças renovadas, porém admitem que frustrações são geradas por expectativas irrealistas.

Em um trabalho onde discutem a percepção da sociedade em relação a famílias recasadas, Coleman e Ganong (1997) afirmam que tanto as crianças quanto os adultos iniciam as relações formadas pelo recasamento com expectativas irrealistas. Na opinião dos autores, a mais problemática de todas as expectativas é que as famílias recasadas possuam um funcionamento igual ao das famílias nucleares. Esse tipo de expectativa pode gerar a suposição, entre os parceiros, que as relações familiares serão automaticamente boas, sem a necessidade de qualquer esforço para que isso aconteça. Tais expectativas são geradas pelas crenças culturais sobre famílias recasadas, que tendem a ser negativas (padrastos e madrastas são maus) ou irrealistas (o amor acontecerá instantaneamente entre os membros da nova família).

E.Visher e J.Visher $(1988,1996)$ também relacionam as expectativas ao que chamam de crenças irrealistas e, assim como Coleman e Ganong (1997) afirmam que dentre as inúmeras crenças que povoam a imaginação dos membros das famílias recasadas, duas são consideradas como tendo um efeito negativo na integração harmônica do grupo familiar; a crença de que a família recasada é uma família nuclear, com todas as características ideais a ela atribuídas pela cultura; e a crença de que o amor instantâneo deverá surgir entre padrasto/madrasta e enteados. Ambas as crenças são baseadas no modelo de família nuclear moderna, difundido socialmente ao longo de décadas.

$\mathrm{Na}$ opinião dos autores, é muito importante que os profissionais que trabalham com famílias recasadas tenham conhecimento das principais crenças "irrealistas", também chamadas de mitos, pois assim serão capazes de ajudá-los a reformular as expectativas de um modo mais realista. Eles descrevem os seis mitos ou crenças que consideram mais prevalentes em relação às famílias recasadas: 1. famílias recasadas são iguais às famílias biológicas; 2. a adaptação da família recasada acontecerá rapidamente; 3. amor e carinho serão desenvolvidos instantaneamente entre os membros da nova família; 4. um esforço 
redobrado por parte da madrasta para agradar os enteados, fará com que ela não seja percebida como "a madrasta malvada"; 5. o afastamento de uma criança de seu pai ou mãe biológico/a, não residente, fará reforçar a sua relação com o padrasto/madrasta do mesmo sexo (por exemplo, o afastamento do pai biológico faria a criança apegar-se ao padrasto); 6. qualquer evento familiar negativo, acontece porque são membros de uma família recasada (Visher e Visher, 1988).

Como foi mencionado anteriormente, a primeira crença é de que as famílias recasadas são iguais às famílias nucleares. Visher e Visher (1988) observam que, embora todas as famílias possuam um sistema de crenças completo de como a família "deve ser", o dos membros da família recasada parece ser o menos congruente com a realidade familiar vivida por eles. Os autores lembram que a família recasada nasce de inúmeras perdas. A perda da família nuclear em si é seguida por uma série de outras perdas emocionais e, na maioria das vezes, de perdas materiais. Os autores afirmam que, antes que novos projetos familiares possam ser plenamente realizados, é necessário que os indivíduos identifiquem e elaborem suas perdas, o que, na opinião dos autores, é uma tarefa importante num contexto de terapia com membros de famílias recasadas.

A segunda crença diz respeito a rapidez de adaptação da nova família. Neste caso os autores comentam que o mito da adaptação instantânea é mais freqüente entre homens do que entre mulheres. Ilustram a questão mencionando as respostas de um grupo de homens recasados à pergunta "o que mais o surpreendeu em sua família recasada"? e todos responderam que acreditavam que a adaptação familiar seria mais rápida. Um dos sujeitos chegou a mencionar que esperava que a adaptação acontecesse em aproximadamente duas semanas. Apontam esse tipo de expectativa como responsável por decepções e, até, por uma nova separação.

A terceira crença refere-se ao amor instantâneo. Existe a idéia de que, por amarem os parceiros, os cônjuges amarão também seus filhos, instantaneamente. A tentativa de forçar o aparecimento de sentimentos de amor e carinho, ainda não existentes entre membros da família recasada, acaba por gerar ressentimentos que dificultam a formação de laços afetivos.

A quarta crença diz respeito à tentativa da madrasta de desmentir a idéia que o seu papel suscita no imaginário popular. A relação entre Cinderela e sua madrasta malvada é bastante conhecida, e há versões da história entre, 
aproximadamente, 300 grupos étnicos no mundo (Visher e Visher, 1988). Neste caso, a crença da mulher é que se ela se esforçar bastante, tentando fazer a família feliz, não se enquadrará no estereótipo negativo da madrasta. Os autores observam que este tipo de comportamento acaba por gerar tensão familiar.

A quinta crença mencionada refere-se ao afastamento da criança de seu pai/mãe biológico, na tentativa de aumentar o vínculo com o padrasto/madrasta do mesmo gênero. Esta crença acaba transformando-se em mais uma tentativa de recriar a família nuclear, excluindo aqueles que poderão interferir no processo. As pesquisas mostram (Visher e Visher, 1988; Kelley, P. 1996; Genovese e Genovese, 1997; Bray, J. e Kelly, J.1998; Bernstein, 1999) que esta tentativa está fadada ao fracasso. Uma relação harmoniosa entre a família recasada e os pais biológicos não residentes, tende a fortalecer os laços entre enteados e madrastas/padrastos.

A última crença mencionada por Visher e Visher diz respeito ao fato dos membros da família atribuírem qualquer evento negativo em suas vidas ao fato de fazerem parte de uma família recasada. Os filhos, freqüentemente, atribuem suas dificuldades escolares, seus problemas relacionais e qualquer outra dificuldade ao recasamento dos pais. Adultos, também, ao enfrentarem problemas familiares, tendem a relacioná-los ao recasamento. O sentimento de culpa dos pais pelo possível sofrimento causado aos filhos com a separação conjugal, acaba sendo relacionado, também, ao recasamento. Os autores afirmam que o recasamento, em si, não cria para a família os efeitos negativos de longo prazo a ele atribuídos. Algumas vezes, entretanto, acontecimentos familiares concomitantes, produzem esta impressão aos membros da família.

Sager e colaboradores $(1971,1983)$ incluem as expectativas do casal recasado no que chamaram de "contrato de casamento". Esclarecem que o contrato, como está sendo descrito aqui, não é um instrumento legal ou consensual entre os parceiros, mas é um conceito utilizado para dar forma a um conjunto de expectativas explícitas e, principalmente, não explícitas dos cônjuges sobre como deve ser a vida conjugal e familiar. Os autores enfatizam a amplitude dos contratos de casamento, que envolvem todos os aspectos da vida familiar: relacionamento com os amigos, ex-cônjuges e respectivas famílias, enteados, vida sexual, relação de poder, atividades de lazer, finanças, filhos, etc. O conteúdo do contrato individual de cada cônjuge é composto por seus desejos e necessidades 
que não são, necessariamente, verbalizados ou pensados de forma conscientes. Enquanto cada um tem uma idéia do conteúdo do próprio contrato, muitas "cláusulas" do contrato do parceiro(a) foram aceitas sem serem conhecidas. É provável que expectativas relacionadas a diversos aspectos da vida familiar sejam frustradas, visto que não são conhecidas pelos envolvidos. Mitos e expectativas sobre o casamento e a família, muitas vezes são levados na "bagagem" dos parceiros para o recasamento.

\subsection{6}

\section{Responsbilidades Parentais}

Decidimos reunir temas que, muitas vezes são tratados em categorias separadas nas pesquisas, como finanças, disciplina e cuidados gerais com os filhos, sob uma única categoria, que chamamos de responsabilidades parentais. Entendemos que, embora sejam diferentes quanto ao conteúdo, os temas tratados nesta categoria envolvem questões semelhantes, tanto no que diz respeito às decisões parentais, quanto à divisão de responsabilidades entre pais biológicos, padrastos e madrastas.

Homens e mulheres resolvem ter filhos pelas mais diversas razões. Porém, ao comprometerem-se na formação de uma relação conjugal, através de rituais e etapas previstas pela sociedade da qual fazem parte, os membros do casal dão origem a uma nova família. A chegada dos filhos representa, para este modelo de família, a possibilidade da continuidade familiar, além da expectativa de uma relação conjugal de longo prazo. Os cuidados diversos em relação aos filhos são, geralmente, divididos por gênero, comportando variações que acontecem de acordo com a condição sócio-econômica dos pais, da região onde vivem, da educação, etc. Não é nossa intenção discutir, neste trabalho, as divergências que surgem nessas famílias, composta por pais biológicos e seu filhos, em relação a "quem faz o que para quem “. É importante ressaltar, entretanto, que elas existem e são temas de freqüentes discussões entre os membros dos casais. O que dizer, então, sobre essas tarefas, quando os pais biológicos não possuem mais o mesmo projeto de vida familiar, e um ou ambos estão tentando construir uma nova vida, com uma nova família? Vejamos o que dizem as pesquisas sobre o tema. 
Sager e colaboradores (1983) incluem as questões financeiras na categoria que chamaram de "forças que atingem o sistema". Para os autores, essas forças estão localizadas fora do sistema familiar mas, de alguma forma, são suficientemente potentes para atingir o seu equilíbrio. Para a grande maioria das famílias, a separação conjugal seguida pelo recasamento representa uma perda financeira que interfere no padrão de vida ao qual estavam acostumadas. As famílias, agora divididas, precisariam de mais recursos para continuar mantendo o estilo de vida anterior. As despesas com educação, roupas, alimentação, cuidados médicos e lazer dos filhos, passam a ser discutidas, não mais por uma única família, mas por diferentes grupos familiares que dividem os recursos.

Genovese e Genovese (1997) apresentam resultados de pesquisas que mostram que as responsabilidades financeiras geradas a partir da separação conjugal e do recasamento são, freqüentemente, relatadas como conflituosas. Segundo os autores, as responsabilidades financeiras, podem gerar ressentimentos tanto na nova construção familiar, como na família separada.

Carter e McGoldrick (1999) compartilham da opinião de Genovese e Genovese (1997) em relação às responsabilidades financeiras com filhos de casamentos anteriores. Acrescentam que, em muitas famílias, os adultos têm que fazer escolhas a respeito do que pagar e para quem. Pais separados possuem expectativas em relação às obrigações financeiras dos ex-cônjuges em relação aos filhos. As despesas dos enteados podem, também, gerar conflitos. Na opinião das autoras, as crianças tendem a perder, financeiramente, quando seus pais recasam.

A questão disciplinar pode tornar-se geradora de conflitos, quando um número maior de adultos está envolvido na criação dos filhos. Para Genovese e Genovese (1997), esta questão é muito pouco clara, ou pouco definida, em famílias recasadas. A posição de padrastos e madrastas desliza entre afirmações do tipo "quase pai/mãe" e "você não é da minha família" ou "você não manda em mim", nas horas em que a imposição de limites se faz necessária. Os autores observam que, embora os problemas entre padrastos/madrastas e seus enteados, relacionados à posição de autoridade, não diminuam a satisfação e a estabilidade do recasamento, conflitos entre os membros do casal sobre o estilo de educar os filhos, estão relacionados ao insucesso das relações conjugais.

A divisão de tarefas relacionadas ao bem-estar dos filhos é, como já foi mencionado, geralmente, feita por gênero. Tradicionalmente, os homens são 
responsáveis pelas despesas de maior porte e as mulheres, pelos cuidados com os filhos, de um modo geral. Mesmo levando em conta o fato desta divisão não ser mais tão rígida hoje em dia, a nova construção familiar acaba impondo novas divisões. Madrastas/padrastos podem não concordar com a idéia de cumprirem tarefas parentais, sejam elas em forma de pagamento de despesas ou de cuidados para com os enteados. Podem, ainda, sentirem-se excluídos, no caso de não participarem, como membros da família, das decisões que dizem respeito à vida dos enteados.

Como mencionamos anteriormente, em um estudo comparativo entre famílias de primeiro casamento e famílias recasadas, realizado através dos filhos adolescentes, Wagner e Sarriera (1999), pesquisadores brasileiros, verificaram que mesmo nas famílias recasadas, "as atribuições de manutenção da prole, vinculadas ao gênero masculino e as de cuidado com o lar relacionadas ao gênero feminino, permanecem" (p.26).

Na opinião de Kelley (1996), a divisão de tarefas deveria privilegiar a relação biológica entre adultos e crianças da família recasada, e não uma divisão de tarefas por gênero. A autora deixa claro que, neste caso, os adultos envolvidos devem ser capazes de cuidar das necessidades de seus filhos biológicos.

A afirmação de Kelley (1996) vem ao encontro da sugestão feita por outros autores (Carter e McGoldrick, 1999) e nos remete à seguinte questão; ao enfatizarmos as relações pelos laços biológicos, não estaremos nos aproximando do modelo de família nuclear? Acreditamos que, tanto a ênfase na divisão de tarefas parentais por gênero quanto na relação biológica entre pais e filhos, afastanos da possibilidade de encontrar um modelo familiar que abranja as relações criadas pelo recasamento.

\section{3}

\section{Famílias Recasadas e Terapia de Família: Um Encontro de Informações}

A revisão da literatura sobre o recasamento nos mostra que, nos EUA, as pesquisas sobre o tema e a prática clínica, caminham lado a lado numa constante troca de informações. Em 1997, por exemplo, a revista americana "Marriage and Family Review" dedicou um volume inteiro às questões do recasamento. Foram 
publicados 18 artigos, 8 dos quais escritos por colaboradores internacionais, que abordaram o tema a partir de perspectivas diversas. Em 2000, a revista "Journal of Marriage and the Family" publicou o trabalho de três estudiosos do recasamento, Marilyn Coleman, Lawrence Ganong e Mark Fine, no qual foi feita uma revisão crítica das principais pesquisas publicadas na década de 90 .

$\mathrm{O}$ contato com as pesquisas internacionais, principalmente americanas, torna evidente a integração de informações entre pesquisadores, terapeutas e membros de famílias recasadas que buscam apoio psicoterápico.

A prática clínica de orientação sistêmica, descrita pela literatura americana, aponta para dois fatores como relevantes no tratamento das famílias recasadas: 1. conhecimento, por parte dos terapeutas, das especificidades e do funcionamento das famílias recasadas; 2. utilização das informações sobre as características e o funcionamento das famílias recasadas, diferenciando-os das famílias de primeiro casamento, como técnica terapêutica. Sobre a utilização de informações na terapia de famílias recasadas, Carter e McGoldrick (1999) observam o seguinte:

\footnotetext{
"Acreditamos que informações que normalizem as experiências do recasamento, são os instrumentos clínicos mais poderosos que possuímos, para ajudar as famílias a negociarem as complexidades das relações criadas a partir do recasamento“ (p.419).
}

A opinião de Kelley, P. (1996) coincide com a de Carter e McGoldrick quanto ao uso de informações como instrumento terapêutico. A autora acrescenta que, famílias recasadas esforçam-se para enquadrarem-se no modelo ideal de família nuclear, e por não conseguirem, acreditam que estão fracassando. $\mathrm{O}$ entendimento e a aceitação de diferentes regras de funcionamento familiar, além da noção de que a diferença não constitui um problema, podem representar transformações importantes na integração e nas interações familiares.

Observamos, no primeiro capítulo deste trabalho, que diferentes épocas produzem diferentes modelos de casamento e de família. Transformações de ordem econômica, política e social, podem ser refletidas em transformações familiares. Ao comentarem sobre famílias recasadas que consideraram funcionais, Carter e McGoldrick (1999) descrevem um posicionamento, por parte dos adultos da família, que implica na necessidade de transformações no comportamento, no desempenho de papéis familiares e nas atitudes destes adultos frente às tarefas 
familiares. Segundo as autoras, a formação de uma família recasada requer, primeiramente, uma revisão dos papéis familiares tradicionalmente divididos por gênero. Afirmam que uma boa interação entre os membros da família requer uma postura de igualdade entre os parceiros e que o exercício das responsabilidades parentais deve privilegiar os laços biológicos ou históricos, no caso de ter havido uma adoção no primeiro casamento.

Entendemos que o recasamento acontece entre casais capazes de lidar com as propostas de igualdade acima mencionadas, entretanto, ocorre também entre casais que mantêm uma postura mais tradicional, na qual a divisão de tarefas é feita por gênero e o homem é o principal provedor da nova família, além de ter uma família por parte do primeiro casamento. Que estratégias terapêuticas podem ser utilizadas nesses casos? De que maneira os adultos deste tipo de relação se posicionam frente as responsabilidades parentais? Acreditamos que a complexidade das relações criadas a partir do recasamento, a instabilidade inicial e a necessidade de construção e reconstrução de relações familiares, originadas por este evento, impõem aos terapeutas de família uma reflexão sobre suas abordagens teórico-práticas utilizadas na compreensão e tratamento dessas famílias.

Em artigos semelhantes, publicados nas revistas especializadas "Journal of Marital and Family Therapy" e "Marriage and Family Review" (1996 e 1997), Emily Visher, John Visher e colaboradores (Kay Pasley e Lyn Rhoden) analisam os resultados de uma pesquisa, na qual adultos recasados que haviam buscado ajuda psicoterápica para tratar de questões relacionadas ao recasamento, falam sobre o processo terapêutico e sobre os resultados por eles alcançados. Como introdução a este trabalho, os autores apresentam uma revisão da literatura clínica sobre o tema, na qual comentam que os primeiros artigos sobre famílias recasadas detiveram-se em identificar os problemas mais comuns inerentes à integração familiar. Filhos de relações anteriores, finanças e o relacionamento com os excônjuges, por exemplo, foram apontados em relatórios clínicos como fatores potencialmente problemáticos, que contribuíam para as dificuldades de adaptação da nova família. Os autores observam que muitas famílias recasadas procuram terapia quando o nível de tensão emocional de seus membros está alto, a integração parece impossível e o próprio funcionamento familiar parece aumentar o nível de estresse, ao invés de reduzi-lo. Em contrapartida aos sintomas 
apresentados pelos membros das famílias recasadas, a literatura clínica apresenta recomendações que têm como objetivo principal a redução da tensão, o aumento da integração familiar e a ênfase no funcionamento da família como um todo. Um dos tópicos mencionados como a ajuda psicoterápica específica mais relevante e mais freqüente, é a compreensão, por parte dos membros da família, das diferenças existentes entre uma família recasada e uma família biológica. Mais especificamente, esta literatura enfatiza a importância do entendimento acerca da estrutura e da dinâmica da família, consideradas centrais para a tarefa de integração familiar. Dentre as questões que afetam negativamente a integração das família recasadas, os autores ressaltam três: a falta de história compartilhada entre os membros da nova família; a falta de clareza em relação às fronteiras que distinguem a nova família das relações familiares de casamentos anteriores; e as questões não resolvidas no passado (traição, abandono, não aceitação das perdas ocorridas na separação), visto que tais questões tendem a emergir numa nova relação.

Apesar da existência de uma vasta literatura sobre as causas das dificuldades encontradas pelas famílias recasadas e das inúmeras recomendações feitas pelos terapeutas sobre como abordá-las, pouco se sabe sobre os efeitos de tais abordagens, na percepção dos clientes. Na realidade, os resultados são, majoritariamente, provenientes de impressões clínicas dos terapeutas. E.Visher, J.Visher e colaboradores $(1996,1997)$ tomaram como ponto de partida uma dissertação de mestrado não publicada (Elion, 1990), onde o objetivo da autora é conhecer a opinião de 32 casais recasados sobre a ajuda obtida por eles, através da terapia, para as questões relacionadas ao recasamento. Tanto o tema quanto o número de participantes da nova pesquisa foram expandidos. Foram enviados 1200 questionários para os membros da Stepfamily Association of America organização americana de âmbito nacional, que presta informações e apoio às famílias recasadas - dos quais 422 foram respondidos e 279 fizeram parte do estudo aqui comentado. Os autores esclarecem que o objetivo da pesquisa era obter dos participantes informações sobre os aspectos por eles considerados positivos e negativos na terapia. A partir das respostas foi possível analisar questões de gênero, como diferentes necessidades de ajuda na percepção de homens e mulheres e, principalmente, o que os sujeitos consideraram como o fator de maior ajuda para a integração e a estabilidade da nova família, relacionado ou 
não à terapia. Segundo os autores, foram utilizadas para fins de análise as seguintes categorias, já descritas pela literatura clínica: 1. Validação das situações familiares e das respostas emocionais; 2.Comunicação entre os membros da família; 3. Autoridade do terapeuta; 4. Psicoeducação.

A validação dos sentimentos ocorre quando o terapeuta normaliza a situação descrita pelos clientes, esclarecendo que elas são comuns nas situações de recasamento. Para as mulheres esta intervenção pareceu de maior ajuda do que para os homens. Seus comentários revelaram que, a validação feita pelo terapeuta de que seus sentimentos não eram estranhos e eram compartilhados por outros em situações semelhantes, ajudou-as a lidar melhor com os sentimentos de culpa e de incompreensão e a diminuir a tensão.

A comunicação refere-se às intervenções que têm como objetivo desenvolver e/ou aprimorar a capacidade de comunicação entre os membros da família. Os homens perceberam esse tipo de intervenção como uma ajuda mais significativa do que as mulheres.

A autoridade do(a) terapeuta também foi mais valorizada pelos participantes do sexo masculino. De acordo com os relatos, os homens sentiram que a opinião de um(a) "especialista" havia sido importante. $\mathrm{O}(\mathrm{A})$ terapeuta foi mencionado(a) como um mediador imparcial das questões levadas pelo casal, um árbitro. Poucas mulheres pronunciaram-se sobre essa categoria, e as que o fizeram afirmaram que a consideraram como uma ajuda, visto que os parceiros "prestavam atenção" às sugestões do(a) terapeuta, e o mesmo não acontecia se as sugestões partissem delas.

Segundo os autores, tanto os homens quanto as mulheres ressaltaram a importância da intervenção denominada de psicoeducação. Nas palavras dos autores, a psicoeducação:

“...clarifica questões, valida sentimentos, normaliza as situações vividas pelas famílias recasadas, ajuda os indivíduos a tornarem suas expectativas em relação à família mais realistas, reduz a sensação de impotência provendo informações e sugestões sobre diferentes formas de lidar com questões que geram estresse aos membros da família" (Visher e Visher, 1997, p.194).

\footnotetext{
* Tradução da autora
} 
Quanto aos fatores considerados como os mais importantes, na opinião do casal recasado, para se alcançar a estabilidade familiar, duas respostas foram mencionadas pelo maior número de participantes de ambos os sexos: o tempo, que não tem qualquer relação com a terapia, e a solidariedade entre os membros do casal, que foi relacionada à terapia, visto que muitas intervenções têm como objetivo o fortalecimento do vínculo conjugal.

A principal causa de insatisfação com a terapia, também na opinião de sujeitos de ambos os sexos, foi a falta de conhecimento, demonstrada por alguns terapeutas, em relação às questões específicas e à dinâmica das famílias recasadas. Alguns dos participantes da pesquisa, que já haviam tido experiências com outros terapeutas, puderam comparar os diferentes profissionais e ilustrar suas respostas através de exemplos pessoais. Ao comentarem a relevância deste dado, os autores observam que terapeutas, freqüentemente, lidam com clientes provenientes de culturas e ambientes diferentes, com os quais não estão familiarizados. Embora seja evidente que o conhecimento das diferenças representa uma ajuda significativa para o tratamento, a escuta cuidadosa aliada a perguntas adequadas possibilitam a formação de uma base de conhecimentos, a partir da qual a terapia poderá se desenvolver. Se existe esta possibilidade em relação a outras diferenças, por que, então, a falta de conhecimento sobre as especificidades do recasamento parece tão crucial? Os autores acreditam que, muitas vezes, os terapeutas não percebem seu desconhecimento sobre a "cultura da família recasada". Para eles, a percepção de família que possuem pode ser aplicada a outras configurações familiares. Prosseguem desta forma, utilizando o modelo de família nuclear, ao invés de fazerem as perguntas necessárias e aceitarem as respostas dos clientes sem pré-julgamentos. Ao contrário dos clientes provenientes de outras culturas, por exemplo, que podem informar seus terapeutas sobre os diferentes aspectos normativos, muitos clientes recasados desconhecem as características e normas das famílias recasadas e sentem-se confusos e impotentes diante da nova realidade. Se o terapeuta também não tiver conhecimento do desenvolvimento, da dinâmica e das possibilidades das famílias recasadas, a terapia perde seu propósito. Os autores acrescentam que, os clientes que têm conhecimento das diferenças entre famílias nucleares e famílias recasadas, reagem negativamente ao desconhecimento ou incompreensão por parte do terapeuta. 
A análise da literatura especializada internacional sobre o recasamento permite-nos concluir que os estudos realizados coincidem na maioria de suas conclusões. Parece não haver divergências básicas em relação à estrutura e à dinâmica das famílias recasadas, ao desempenho de papéis criados a partir do recasamento assim como em relação às recomendações apresentadas aos terapeutas como ajuda específica aos membros desse formato de família. Dentre os conhecimentos e características específicas identificados como relevantes à condução do processo terapêutico, o conhecimento e a compreensão, por parte dos terapeutas, da dinâmica dessas famílias é mencionado como requisito fundamental para a obtenção de resultados positivos (Sager e colaboradores, 1983; Carter e McGoldrick, 1995, 1999; Visher e Visher 1988, 1996, 1997). É importante notar que, paralelamente ao conhecimento específico sobre o funcionamento das famílias recasadas, as pesquisas ressaltam a importância do conhecimento por parte dos terapeutas a respeito das expectativas sociais e sua influência sobre essas famílias, para que eles possam intervir terapeuticamente, utilizando recursos apresentados na literatura como, por exemplo, a chamada validação e normalização dos sentimentos e do funcionamento da família recasada. A sociedade se encarrega dessa função no caso da família nuclear, onde os papéis a serem desempenhados por seus membros já foram definidos. A transposição desses papéis para um novo modelo de família, porém, é reconhecida como geradora de dificuldades. Ao terapeuta cabe a função de apresentar e debater os novos papéis familiares, buscando tornar as expectativas familiares mais realistas. O reconhecimento, por parte do terapeuta, das dificuldades vividas pelos clientes recasados na integração de famílias e histórias diferentes e as sugestões a respeito de novas regras familiares, ajudam a família a compreender que, a despeito das situações provocadoras de ansiedade, a família não sofre de uma "patologia” por ser recasada.

As pesquisas clínicas sugerem que o terapeuta tenha uma função didática, informando os membros das famílias recasadas sobre o funcionamento da nova família. A chamada psicoeducação é considerada um recurso terapêutico fundamental (Carter e McGoldrick, 1999; Visher e Visher, 1988,1996, 1997).

Visher e Visher (1988) sugerem que os terapeutas que trabalham com famílias recasadas devem utilizar nomeações adequadas para referirem-se às relações intrafamiliares. Segundo os autores, visto que a linguagem reflete e 
determina as crenças, a linguagem usada pelo terapeuta transmite seu conceito de família aos clientes. Observam que, como não há na língua inglesa uma terminologia "confortável” para descrever as relações familiares entre membros de famílias recasadas, as crenças irrealistas dos clientes podem ser reforçadas através do uso de terminologia inadequada. Como exemplo citam o fato do terapeuta referir-se ao padrasto ou madrasta como seu "novo pai" ou sua "nova mãe”. Para Lewis (1980), citado por Visher e Visher (1988), a função do terapeuta é ajudar as famílias a encontrarem palavras congruentes com as suas próprias situações familiares.

O aprimoramento da capacidade de comunicação e de negociação também foram consideradas tarefas terapêuticas para as famílias recasadas. Visher e Visher (1988) observam que a união das famílias pelo recasamento busca criar integração e intimidade, rapidamente, entre indivíduos de idades diferentes que provêm de diferentes experiências familiares. Embora o mesmo aconteça num primeiro casamento, com os parceiros, a situação é mais complexa no recasamento, onde filhos de idades diferentes, que possuem hábitos diversos, passam a conviver no mesmo espaço, supostamente sob as mesmas regras de convivência. A comunicação e a negociação ajudam a clarificar as expectativas em relação aos novos papéis familiares, aumentam a sensibilidade em relação às necessidades dos outros e facilitam a adaptação às mudanças estressantes que fazem parte da vida das famílias recasadas (Visher e Visher e colaboradores, 1996).

Outra tarefa terapêutica mencionada refere-se à separação entre sentimentos e comportamentos. Na opinião de Visher e Visher (1988), é importante ressaltar para os membros da família que, embora tenhamos pouco controle sobre nossos sentimentos, muitas vezes nos esquecemos que, geralmente, temos a possibilidade de controlar nossas atitudes. Segundo os autores, a clarificação deste fato pode aliviar os padrastos e madrastas do sentimento de culpa que os aflige por terem sentimentos negativos em relação aos filhos de seus parceiros.

O fortalecimento do vínculo conjugal também é mencionado como uma tarefa terapêutica de relevância, em se tratando de famílias recasadas. Muitas vezes os membros do casal sentem-se divididos entre os próprios filhos e o(a) parceiro(a) ou entre seus filhos e os do(a) parceiro(a). Sem perceberem acabam 
por colocarem-se em lados opostos, enfraquecendo o vínculo entre eles. A solidariedade entre os membros do casal, fator que os ajudará a lidar mais facilmente com a complexidade familiar, é desenvolvida a partir do fortalecimento do vínculo conjugal (Visher e Visher e colaboradores, 1997).

Quem deve ser atendido numa terapia de família recasada é uma questão constantemente levantada pelos autores que dedicam-se ao tema. Para esta questão, também, parece haver uma certa concordância. À medida que o fortalecimento do vínculo conjugal é considerado uma tarefa terapêutica importante, os estudiosos concordam que o casal deve ser atendido sem os filhos (Visher e Visher 1988, 1996, 1997).Não há regras rígidas em relação a este fato, e as situações devem ser analisadas individualmente. Os autores observam, também, que esta é uma questão que precisa ser aprofundada.

Para nós, que pesquisamos o tema através da própria prática clínica, no Rio de Janeiro, bem como através de estudos exploratórios anteriores com membros de famílias recasadas, foi interessante observar o nível de informação, em relação ao recasamento, de alguns sujeitos da pesquisa que avaliou resultados terapêuticos a partir da perspectiva de clientes adultos (Visher e Visher e colaboradores 1996,1997). Este fato nos remete, mais uma vez, às questões levantadas por esta pesquisa. Que tipo de família recasada busca ajuda terapêtica, no Rio de Janeiro? Que informações esses clientes possuem antes de chegar à terapia? De que forma os terapeutas de família do Rio de Janeiro estão ajudando as famílias recasadas? Estas questões estarão presentes na pesquisa de campo, na qual o grupo de participantes, composto por dez terapeutas de família do Rio de Janeiro, poderá delinear as características das famílias recasadas que atendem. 


\section{3}

\section{Terapias e Terapeutas de Família}

\section{1}

\section{Transformações na Terapia de Família}

Desde o início do presente estudo, tínhamos a intenção de desenvolver um capítulo sobre terapia de família, com o objetivo de ilustrar o trabalho dos terapeutas e estudiosos do recasamento mencionados no capítulo 2. Através da análise do suporte teórico que direciona o trabalho do terapeuta, torna-se possível entender sua visão de um modelo de família, as possíveis intervenções que ocorrem ao longo da terapia, além de sua concepção sobre o papel do terapeuta de família e do lugar ocupado por ele no contexto terapêutico. Partindo desta premissa, decidimos realizar o estudo de campo antes de concluirmos o presente capítulo, para que pudéssemos incluir aqui as teorias e os autores que norteiam as práticas clínicas de nossos entrevistados. Consideramos tais informações relevantes para entendermos o modo como esses profissionais lidam com as transformações familiares contemporâneas em suas práticas e, principalmente, com situações relacionadas ao recasamento.

Assim como as diversas configurações familiares possíveis no recasamento são colocadas num mesmo bloco e chamadas de "famílias recasadas", estamos acostumados a ouvir a expressão "terapia de família" como se esta fosse “... um empreendimento monolítico, uma abordagem programática do tratamento, com um conjunto coerente de conceitos e métodos" (Nichols \& Schwartz, 1998, p.21). Não há, entretanto, uma Terapia de Família, mas várias abordagens assim chamadas, cada uma conceituando e tratando as famílias de forma diferente. Assim como não existe, também, um formato único de família no recasamento, visto que cada família recasada constrói-se a partir da história pessoal de cada membro do casal, com a "bagagem" trazida por eles de relações conjugais e familiares anteriores.

Os autores acima mencionados observam que persiste a impressão geral de uma continuidade linear na história da Terapia de Família, onde as transformações 
são percebidas como especializações. Esclarecem, no entanto, que jamais existiu um consenso, entre os primeiros terapeutas, em relação aos princípios gerais de tratamento na Terapia de Família. Acrescentam que a Terapia de Família foi desenvolvida por um "grupo heterogêneo de investigadores, trabalhando em contextos bastante diferentes e com propósitos diferentes" (p.21). As palavras de Nichols e Schwartz (1998) evidenciam que a variedade, não a unidade, tem sido a marca da história da Terapia de Família. Quanto aos pioneiros deste campo tão fértil, os autores comentam que eles "descobriram a terapia familiar antes de descobrirem um ao outro". Esses comentários evidenciam que o desafio enfrentado por um historiador que tem a intenção de narrar a história da terapia familiar não é o de descrever as diferenças entre várias abordagens, mas de buscar os pontos comuns que as unem. Assim como é um desafio para nós tentarmos articular as diferentes abordagens de terapia familiar, utilizadas no tratamento da família recasada. A que terapia e a que família estamos nos referindo?

Ao longo da pesquisa, tornou-se cada vez mais evidente para nós que não há como dissociarmos as abordagens psicoterápicas dos contextos sóciohistóricos onde elas surgem, se desenvolvem e, numa relação mais direta com a questão mencionada no parágrafo anterior, onde elas são praticadas.

Antes mesmo de pensarmos sobre as múltiplas influências que precederam e facilitaram o desenvolvimento da terapia familiar, ou das contribuições que as diversas áreas de conhecimento acrescentaram ao campo, é importante lembrarmos que um diálogo entre todos os membros de uma família, como acontece numa sessão de terapia de família, aponta para uma nova possibilidade nas relações familiares, que tradicionalmente eram hierárquicas. Nas palavras de Ponciano (1999):

\footnotetext{
"A Terapia de Família, seja ela de que linha teórica for, insere-se na possibilidade do diálogo pautado na democracia, ou seja, nas idéias de direitos iguais para todos, sendo essa visão fundamental para reunir uma família em uma sessão terapêutica com um especialista, com o objetivo de que todos tenham voz e decidam quanto ao rumo de seus problemas. Em uma visão tradicional das relações familiares, pautada tão somente na hierarquia, isso não seria possível” (Ponciano, 1999, p.216).
}

As famílias só começaram a ser tratadas como um grupo a partir de meados da década de 50. Nichols e Schwartz (1998) observam que, embora as 
duas abordagens terapêuticas mais influentes até então, a psicanálise de Freud e a terapia centrada no paciente, de Rogers debitassem às relações familiares os problemas psicológicos apresentados pelos indivíduos, os membros da família não faziam parte do tratamento. Ainda que partindo de pressupostos teóricos e procedimentos clínicos diferentes, as duas abordagens propunham a mais absoluta privacidade no relacionamento terapêutico.

Em relação aos tratamentos e internações psiquiátricas, embora o papel da família também fosse reconhecido na etiologia dos distúrbios, acreditava-se que a sua influência negativa poderia ser anulada se esta fosse excluída do convívio e do tratamento dos pacientes. Foi, contudo, a partir de pesquisas sobre a comunicação entre pacientes esquizofrênicos e suas famílias, com seus padrões de interação considerados dramáticos e visíveis, que evidenciou-se a importância de um tratamento envolvendo a família.

A idéia de atender a família, ao invés de apenas um de seus membros identificado como aquele que tem ou causa problemas, enfatiza o que é considerado uma das maiores contribuições da terapia familiar para o campo da saúde mental, que é o entendimento dos comportamentos do indivíduo dentro de seu contexto. Na opinião de Bateson (1979), que dirigiu o projeto de esquizofrenia, em Palo Alto, EUA, considerado o marco inicial da Terapia de Família, "é o contexto que determina o significado". Dentro do contexto familiar, comportamentos que pareciam estranhos em atendimentos isolados, passaram a fazer sentido, sendo compreendidos como reflexos de como a família havia se desenvolvido.

Desde o início, os estudiosos e terapeutas de família procuravam demonstrar que a família era o contexto dos problemas humanos e esta, como outros grupos humanos, tinha propriedades emergentes. Uma dessas propriedades explicitava que o todo era maior que a soma de suas partes. Independente da variedade de explicações sobre as propriedades emergentes deste grupo humano, elas acabavam por ser divididas em duas categorias: estrutura e processo. Dentro das abordagens de orientação sistêmica, a estrutura da família inclui triângulos, subsistemas e fronteiras. Os processos referem-se às interações familiares e são descritos como reatividade emocional e comunicação disfuncional, entre outros. O conceito central é o de circularidade, que afirma que um todo não possui começo nem fim, o que dificulta a atribuição de responsabilidade da origem de 
um problema familiar a um dos membros da família atendida (Calil, V.,1987; Elkaïm, M., 1998;).

No início da década de 1970, a terapia familiar atingiu o seu ponto mais alto de reconhecimento. Contava com inúmeros adeptos, publicações e conferências próprias, apesar de não possuir homogeneidade em torno de uma teoria ou abordagem, como a terapia comportamental ou a psicanálise, por exemplo. Uma revisão da literatura nos mostra que, na história da terapia de família, a visão da família que as diferentes abordagens tentavam compreender, não era diferenciada. As descrições dessas famílias relacionavam-se, diretamente, ao modelo de família nuclear, composta por pai, mãe e filhos biológicos, e diferenças étnicas, de classe, de poder entre homens e mulheres na família, ou qualquer outra variação na constituição familiar que pudesse interferir na concepção deste modelo, não eram adequadamente valorizadas, tornando-se invisíveis. Os terapeutas de família mantinham uma postura hierárquica, na qual eles eram os especialistas, detentores de um saber específico sobre as famílias que atendiam. A terapia era o instrumento utilizado por esses especialistas para reorganizar o que chamavam de estrutura familiar disfuncional, para que, a partir de então, a família pudesse resolver seus problemas.

A partir da década de 1980, porém, da mesma forma que ocorreu em outras áreas do conhecimento, como na literatura, nas artes, no direito, na educação, na arquitetura, entre outras, idéias como a existência de uma verdade única a ser descoberta, o papel do especialista, a busca pela objetividade como demonstração de eficiência, e outras premissas valorizadas como bases sólidas de conhecimento até então, começaram a ser desafiadas por alguns estudiosos da área de terapia de família. Em lugar das certezas produzidas pelos diversos saberes, iniciou-se uma era de ceticismo, chamada de movimento pós-modernista, em cuja base está a suposição de que não há realidades objetivas, mais verdadeiras do que outras, mas convenções socialmente desenvolvidas e aceitas, carregadas de ideologias próprias ou motivos tendenciosos. Embora não tenhamos a intenção de discutirmos, no presente estudo, se podemos ou não caracterizar este momento social como pós-moderno, achamos relevante discutir a própria nomeação reivindicada pelos terapeutas de família que fazem crítica às concepções modernas de família e de terapia de família. Para Lynn Hoffman (1995), por exemplo, a visão pós-moderna das Ciências Humanas, 
“... desafia qualquer questão referencial que pressuponha algum tipo de estrutura interna à entidade em questão, quer estejamos falando a respeito de um texto, de uma família ou de uma peça. Para a terapia familiar, isso gerou críticas à visão cibernética, que entende a família como um sistema homeostático “(p.14).

O construtivismo e o construcionismo social, abordagens identificadas como pós-modernas, direcionam seu foco de interesse não mais para avaliação e modificação do comportamento interacional dos membros de uma família, mas para as narrativas pessoais, geradas a partir de crenças socialmente construídas. Embora essas abordagens tenham origens e posições diferentes, e não seja nossa intenção aprofundarmos o tema no presente trabalho, elas são freqüentemente mencionadas juntas pelas suas semelhanças. Ambas direcionam seus interesse para o modo como as pessoas constróem a realidade e dão significado às suas vidas. O que diferencia as duas abordagens é a origem dessas construções. Enquanto o construtivismo descreve a construção do saber a partir de processos individuais, o construcionismo social busca a origem das construções nas relações sociais (Gergen e McNamee, 1995; Lynn Hoffman, 1998; Elkaïm, 1998; Nichols e Schwartz, 1998;).

A partir da introdução das noções construtivista/ construcionista social no campo da terapia de família, o discurso clínico teve que ser modificado. Não era mais possível se acreditar na superioridade de uma abordagem em relação à outra, pela suposição de que esta tinha uma maior correspondência com a realidade objetiva, visto que para essas abordagens não existe um mundo real e objetivo a ser descoberto, mas construções do mundo real feitas pelos indivíduos, inseridos em suas culturas. Não há construções mais corretas ou melhores do que outras, apenas construções diferentes.

Em um estudo onde analisa as modificações no contexto atual da terapia de família, Rapizo (1998), terapeuta de família do Rio de Janeiro, observa que não há mais lugar para certezas e que o terapeuta convive, atualmente, “ com a angústia do indeterminado, do imprevisível". A autora comenta, revelando o relativismo presente no campo:

\footnotetext{
"Não há um único modelo clínico a ser seguido. Há quase tantos modelos como terapeutas. Temos parâmetros organizadores que podemos adotar em nossa clínica. Mas estes parâmetros, no caso da terapia construtivista, ou de segunda ordem, referem-se basicamente à coerência da prática com a teoria, com a posição epistemológica. Não são regras a serem seguidas, nem a única maneira de alcançar tal coerência “(p.99).
} 
Conforme mencionamos anteriormente, optamos por apresentar aqui as abordagens teóricas e os autores mais freqüentemente citados por nossos entrevistados. Observamos, através da análise das entrevista de nossos sujeitos, que suas preferências teóricas acabaram por apontar para correntes teóricas diferentes. Ficou evidente, entretanto, a prevalência de duas direções principais: a Terapia de Família Estrutural, cujo principal representante, Salvador Minuchin, é repetidamente mencionado pelos entrevistados; e as abordagens surgidas a partir do movimento pós-modernista, informadas pelo construtivismo e pelo construcionismo social. Com base nessas preferências, optamos por fazer uma breve apresentação dessas abordagens, para que tenhamos a possibilidade de articula-las com os discursos dos sujeitos.

\title{
3.2
}

\section{Terapia de Família Estrutural}

\begin{abstract}
"Considero o processo terapêutico como um encontro entre culturas interpessoais distintas. O respeito real pelos pacientes e por sua integridade pode permitir aos terapeutas serem outra coisa além de timidamente cautelosos; pode encorajá-los a serem diretos e autênticos - respeitosos e compassivos - , mas também às vezes honestos e desafiantes" ( Minuchin, S, 1998, p.17).
\end{abstract}

Na década de 1970, a terapia familiar, já com 20 anos de existência, chega à maturidade. Neste período, a chamada Terapia de Família Estrutural surge como a abordagem mais influente do campo. Uma das possíveis razões desta influência refere-se ao "fantástico virtuosismo" de seu principal expoente, Salvador Minuchin. A princípio, mais conhecido como clínico do que como teórico, podemos dizer que sua contribuição maior e de impacto mais duradouro para a terapia familiar tenha sido o desenvolvimento de uma teoria da estrutura familiar e de um conjunto de diretrizes para a organização das técnicas terapêuticas. Ele concluiu que as famílias que entravam em tratamento pareciam estar paralisadas devido ao que percebiam como a ausência de alternativas. $\mathrm{Na}$ opinião de Minuchin, a terapia destinava-se a "descongelá-las" de hábitos rígidos, criando a oportunidade para o surgimento de novas estruturas. O sucesso conquistado por ele e pela abordagem estrutural acabou por transformar a Philadelphia Child Guidance Clinic, onde trabalhava na década de 70, num centro de treinamento de terapeutas de família de fama internacional. A partir da experiência de trabalhar 
com meninos delinqüentes e suas famílias na Wiltwyck School, sentiu a necessidade de desenvolver novos conceitos e técnicas que pudessem ser utilizadas com aquelas famílias, visto que, naquele período, os primeiros terapeutas de família estavam trabalhando com famílias de classe média, e as abordagens utilizadas por eles não pareciam adequadas para serem aplicadas às famílias pobres de Wilwyck. Uma dessas técnicas foi a da representação, que implicava em trazer para a sala de terapia as seqüências das interações familiares, representadas pela família, para que o terapeuta tivesse a possibilidade de observá-las e de intervir sobre elas. Minuchin é conhecido por utilizar técnicas concretas e voltadas para a ação, características que desde então continuam a marcar a Terapia de Família Estrutural.

A Terapia de Família Estrutural oferece uma estrutura clara que visa a proporcionar ordem e significado às transações das famílias. São os padrões consistentes, repetitivos, organizados e previsíveis do comportamento familiar que nos permitem considerar a existência de uma estrutura. É importante enfatizar que a noção de estrutura para Minuchin refere-se à possibilidade de visualização do padrão de funcionamento das famílias, e não à busca de um significado subjacente. Embora as fronteiras emocionais e as coalizões que compõem a estrutura familiar sejam abstrações, a utilização deste conceito permite aos terapeutas intervenções sistemáticas e organizadas. Na realidade, a Terapia de Família Estrutural é um plano para analisar o processo das interações familiares, o que, na opinião dos terapeutas que a utilizam, proporciona uma base para estratégias de tratamento consistentes.

A teoria estrutural da família compõe-se de três elementos essenciais: 1. estrutura; 2. subsistemas; 3. fronteiras. Nas palavras de Minuchin (1990a):

1 .'A estrutura familiar é o conjunto invisível de exigências funcionais que organiza as maneiras pelas quais os membros da família interagem. Uma família é um sistema que opera através de padrões transacionais" (p.57).

2. "O sistema familiar diferencia e leva a cabo suas funções através de subsistemas. Os indivíduos são subsistemas dentro de uma família. Díades, tais como esposo-esposa e mãe-filho, podem ser subsistemas. Os subsistemas podem ser formados por geração, sexo, interesse ou por função" (p.58).

3. "As fronteiras de um subsistema são as regras que definem quem participa e como... A função das fronteiras é de proteger a diferenciação do sistema. Cada subsistema familiar tem funções específicas e faz exigências específicas a seus 
membros ... Para o funcionamento apropriado da família, as fronteiras dos subsistemas devem ser nítidas" (p.58).

A estrutura da família é moldada por limitações universais, como por exemplo, todas as famílias têm algum tipo de estrutura hierárquica, na qual pais e filhos exercem graus diferenciados de autoridade, e por limitações idiossincráticas. Os membros da família desenvolvem funções recíprocas e complementares, se o pai/mãe é muito responsável, o outro será menos; se por algum motivo o mais responsável está ausente, o outro assumirá sua função, de alguma maneira.

Os padrões transacionais utilizados por uma família, que surgem a partir de uma determinada situação do ciclo de vida familiar, tendem a perpetuarem-se e a tornarem-se resistentes à mudança. Acabam por fazer parte do funcionamento familiar de tal forma, que as famílias não consideram outras alternativas disponíveis, até que, por novas exigências de transformação do ciclo de vida familiar, estes padrões produzam "estresse" e "disfunção no sistema".

A estrutura da família só se torna evidente para o terapeuta, quando este tem a possibilidade de observar interações reais entre todos os membros da família, no decorrer do tempo.

As fronteiras demarcam os indivíduos, os subsistemas e as famílias, como um todo. Servem para proteger a autonomia da família, delimitando o grau de proximidade e de hierarquia que é gerado no sistema.

Minuchin (1990a) afirma que é importante, para um terapeuta de família, saber o que é um desenvolvimento familiar normal, para reconhecer o anormal. A normalidade, na terapia familiar estrutural, é definida em termos de realização funcional, e os terapeutas estruturais reconhecem que padrões diversos podem ser funcionais. A noção de etapas do ciclo de vida familiar é utilizada como uma referência a mais na avaliação de um sintoma familiar, que representa a dificuldade de passar de um estágio a outro. Para o autor, os clínicos têm que ter, em primeiro lugar, uma apreciação "emocional" e "intelectual" dos fatos da vida familiar comum, para tornarem-se terapeutas eficientes. É importante que tenham conhecimento das adaptações necessárias para que as transições das diferentes fases do ciclo da vida familiar sejam bem sucedidas. Segundo Minuchin (1990a; 
1990b; 1995), a experiência de vida do terapeuta contribui para a compreensão dos problemas apresentados pelas famílias.

Minuchin (1990b) enfatiza a importância do casal ou do subsistema conjugal para o desenvolvimento e a manutenção da estabilidade familiar. Afirma que, em se tratando de Terapia de Família, é relevante conceituar o começo da família como "o encontro no qual dois adultos, um homem e uma mulher, se unem com o propósito de formá-la” (p.26). O autor acrescenta que esta união não precisa ser legalizada para ser significativa. Acredita que, embora sua experiência clínica com casais homossexuais com filhos seja limitada, os conceitos da Terapia de Família são igualmente válidos para tais casais. Em suas palavras:

"O subsistema conjugal é vital para o crescimento dos filhos. Constitui seu modelo para relações intimas, como se expressam nas interações cotidianas. No subsistema conjugal a criança vê meios de expressar afeto, de se relacionar com um parceiro em dificuldades e de lidar com o conflito com iguais. $\mathrm{O}$ que ela vê se tornará parte de seus valores e expectativas, quando entrar em contato com o mundo exterior" (p.27).

$\mathrm{Na}$ opinião do autor, disfunções relevantes entre os membros do subsistema conjugal repercutem em toda a família e, em situações mais graves, uma criança pode fazer uma aliança com um dos cônjuges contra o outro. Observa que o terapeuta de família deve estar alerta para o envolvimento dos filhos em situações conjugais conflitantes, que tendem a incluí-los em um subsistema ao qual não pertencem.

Segundo Minuchin (1990a), no início do casamento o jovem casal enfrenta uma série de tarefas, para que ocorra uma acomodação mútua em pequenas rotinas. Para tanto o casal desenvolve um conjunto de transações padronizadas que acabam por formar uma "rede invisível" de exigências complementares, que regulam um grande número de situações familiares. Os membros do novo casal possuem a tarefa de negociar novas formas de relação não apenas com os pais, irmãos e parentes, mas até com os amigos. Nas palavras do autor:

\footnotetext{
"O casal também enfrenta a tarefa de separação de cada família de origem e de negociar uma relação diferente com pais, irmãos e parentes afins. As lealdades devem mudar, porque os compromissos fundamentais dos novos esposos são com seu matrimônio. As famílias de origem devem aceitar e apoiar esta ruptura". (...) "Cada esposo deve travar conhecimento com os amigos do outro e selecionar os que devem tornar os amigos do casal. Cada um pode ganhar novos amigos e perder contato com antigos" (Minuchin, 1990a, p.26).
} 
O nascimento do primeiro filho dá início a uma nova fase na vida familiar. O subsistema conjugal deve diferenciar-se para desempenhar as novas tarefas do subsistema parental. O processo parental vai se modificando ao longo do ciclo de vida familiar, dependendo da idade dos filhos.

O nascimento do segundo filho inaugura o subsistema fraternal que, na opinião de Minuchin (1990a), é “o primeiro laboratório social, no qual as crianças podem experimentar relações com iguais" (p.63).

As descrições feitas por Minuchin (1990a) das tarefas que um jovem casal enfrenta no início de uma nova família e com o nascimento dos filhos, apontam para a formação familiar representada pelo modelo de família nuclear moderna. Ao longo de seu trabalho, o autor faz observações sobre as transformações "introduzidas pela sociedade industrial urbana" que, na época, influenciavam a vida da família americana ( o livro foi publicado nos EUA em 1974, pela primeira vez, com o título de Families and family therapy ). Menciona, por exemplo, o fato de ambos os cônjuges trabalharem fora. Embora essas transformações tenham sido apresentadas como momentos transicionais importantes, que exigiam adaptações por parte das famílias, não pareceu haver um questionamento relativo à necessidade de mudança na noção de modelo de família.

Ao falar de recasamento, Minuchin (1995) observa que "em nenhum lugar da vida familiar os triângulos são mais claramente problemáticos do que nas famílias de segundo casamento “(p.185). Acrescenta que o maior erro que as famílias do novo casamento cometem é tentar adaptar-se ao modelo tradicional de família nuclear. Todas essas idéias nos fazem refletir sobre algumas questões, tais como, que modelo de família influencia os terapeutas de família de orientação estrutural hoje? Que modelo de família os influencia quando atendem uma família recasada? Se, para que o terapeuta de formação estrutural perceba a estrutura da família, é necessário que ele a observe em ação, no caso da família recasada, quem é recebido na sessão de terapia?

A noção de um ciclo de vida familiar ou de desenvolvimento familiar normal, remete-nos, mais uma vez, para a questão da separação conjugal e do recasamento. Como mencionamos em capítulo anterior, quando Carter e McGoldrick (1999) afirmam que muitas das dificuldades da família recasada, podem ser atribuídas às tentativas da própria família ou do(a) terapeuta de utilizar 
como modelo os papéis e as regras de famílias de primeiro casamento, as autoras afirmam, também, que é necessário a criação de um novo paradigma de família que contemple os relacionamentos das famílias recasadas.

Estas questões, que se relacionam ao mesmo tempo com a abordagem teórica utilizada pelo terapeuta, com sua prática clínica e com os nossos objetivos referentes ao entendimento da situação familiar criada pelo recasamento, serão retomadas e analisadas através das entrevistas com terapeutas de família do Rio de Janeiro.

\section{3}

\section{O Construtivismo e o Construcionismo Social}

Como mencionamos anteriormente, a década de 1980 introduz no campo da terapia familiar, até então empenhado no desenvolvimento de técnicas cada vez mais objetivas e pragmáticas, a possibilidade de uma autocrítica. Conceitos básicos utilizados em terapia de família como homeostase, resistência e paradoxo, começaram a ser questionados (Keeney \& Sprenkle, 1982; Keeney, 1983; Dell, 1982,1985). As críticas centravam-se no fato do campo estar voltado para técnicas e resultados, negligenciando considerações mais abrangentes sobre as famílias, que fugissem dos parâmetros determinados pelos modelos existentes. As metáforas utilizadas no processo terapêutico pareciam ter valor de verdade para os terapeutas de família. Esta reavaliação serviu para criar um ceticismo em relação à crença de objetividade e à metáfora cibernético-sistêmica bastante valorizadas até então (Elkaïm, M.,1998).

Segundo Elkaïm (1998), foi a partir da publicação da obra dirigida por Paul Watzlawick, "L'Invention de la realité” (1981), originalmente publicada em alemão, que divulgou-se entre os terapeutas de família um novo movimento, conhecido como construtivismo. Como ilustração apenas, visto que não é nossa intenção aprofundarmo-nos no estudo deste tema, citamos o que Nichols e Schwartz (1998) comentam sobre autores de diferentes áreas, que contribuíram com idéias construtivistas, mais tarde incorporadas por terapeutas de família:

\footnotetext{
"Estas novas suposições caíram vagamente sob a rubrica do construtivismo, uma filosofia que surge de algumas idéias da neurobiologia - por exemplo, a crença de Maturana e Varela (1980) de que os sistemas vivos são unidades neurais autocontidas que podem não
} 
ter experiência direta de seus ambientes; o lembrete de von Foerster (1981) de que os observadores têm um efeito sobre os sistemas que interpretam; e o 'construtivismo radical' de von Glaserfeld (1984), que diz que nunca podemos conhecer o mundo real, apenas nossas imagens internas dele" (Nichols \& Schwartz, 1998, p.120).

A partir das idéias lançadas pelos teóricos construtivistas, alguns terapeutas de família passaram a refletir sobre a importância da construção do real que ocorre, reciprocamente, em psicoterapia. Esta noção passou a ocupar um lugar mais relevante do que a pesquisa da verdade ou da realidade provinda de um contexto externo. Na opinião de Elkaïm (1998), esta mudança na maneira de perceber o contexto terapêutico acarretou algumas implicações importantes para a prática psicoterápica. Uma delas diz respeito ao resultado da terapia, que passa a não estar mais relacionado ao fato do terapeuta "ter razão" ou "estar correto" quanto às dificuldades ou conflitos apresentados pelos clientes, mas considera se a construção levantada reciprocamente é bem sucedida. No que diz respeito às intervenções efetuadas pelo terapeuta, ao invés do objetivo estar direcionado ao surgimento de uma "verdade qualquer" que, segundo o autor, é "pretensamente aproveitável para o sistema, ou para seus membros", passa a ser direcionado, acima de tudo, a ampliar o campo do possível.

Nichols e Schwartz (1998) também comentam sobre as implicações da posição construtivista para o campo da terapia de família. Segundo os autores, à medida que o construtivismo determina que a realidade só existe dentro do contexto, como uma construção mental do observador, os terapeutas devem compreender que o que estão vendo nos clientes é o produto de suas próprias suposições sobre pessoas, famílias e problemas, além de suas próprias interações com a família atendida. Segundo os autores, esta posição teve como conseqüência tornar os terapeutas mais humildes em sua maneira de lidar com os clientes, a medida que sua avaliação passa a ser apenas mais uma dentre as muitas histórias possíveis sobre determinada família.

A partir da disseminação das idéias construtivistas no campo da terapia de família, alguns terapeutas passaram a refletir sobre suas práticas e a buscar uma posição muito mais colaborativa em relação à família e voltada para o significado, deixando de ser diretores ou especialistas, como vinha acontecendo até então. Este movimento tornou-se conhecido como "terapia familiar de segunda ordem", para 
diferenciá-lo dos movimentos iniciais de terapia familiar, com seus aspectos estratégicos e hierárquicos.

No final da década de 1980, nos Estados Unidos, teorias relativas ao construcionismo social começaram a tomar impulso. Kenneth J. Gergen, psicólogo social e professor do Swarthmore College, na Pensilvânia, e principal expoente do construcionismo social, propõe que os terapeutas substituam as metáforas mecanicistas da cibernética por metáforas utilizadas na teoria literária ou na antropologia pós-moderna. Em sua opinião, o construcionismo social situase na era pós-moderna, definindo o modernismo como uma visão de mundo que tem raízes nos séculos XVI E XVII. Em relação a essas diferentes visões de mundo, Gergen observa que o modernismo fazia uma analogia entre o mundo e uma máquina gigantesca que poderia e deveria ser compreendida pelo homem, o que produziria conhecimento e progresso. O pensamento pós-moderno, que teria tido sua origem associada a um momento de contestação de uma política de acúmulo de poder e de riquezas, no final da década de 1960, faz uma associação entre reivindicação ética e desconstrução dos conceitos de racionalidade, objetividade e progresso (Gergen, 1994; Elkaïm, 1998). Gergen (1985) enfatiza o poder da interação social na geração de significado para as pessoas. Segundo o autor, além de não termos a possibilidade de percebemos a realidade objetiva noção compartilhada pelo construtivismo - as realidades por nós construídas se ancoram nos sistemas de linguagem em que existimos. A noção de autonomia individual em relação às crenças que mantemos também é desafiada por Gergen, que deduz que essas crenças são passíveis de mudanças drásticas direcionadas pelo contexto social em que vivemos (Gergen, 1985, 1994; Elkaïm, 1998; Nichols e Schwartz, 1998).

A noção introduzida por Gergen de que a construção do mundo não se situa no interior da mente daquele que observa, mas no interior das diversas formas de relação, traz uma série de implicações para o campo da psicoterapia. Os intercâmbios verbais entre terapeuta e cliente, por exemplo, não refletem mais verdade alguma. O que existe é o estabelecimento de um diálogo potencialmente produtivo entre eles, sem qualquer tipo de verificação ou de aplicação de uma teoria preconcebida. Visto que os significados são co-gerados pelo cliente e pelo terapeuta no contexto terapêutico, já não há mais uma voz única. $\mathrm{O}$ papel do terapeuta passa a ser auxiliar o cliente, a partir do aspecto pragmático da 
linguagem terapêutica, a permitir o aparecimento de outras vozes internas, que poderão dar outras direções e formas para a conversação.

A partir das idéias provindas do construtivismo e do construcionismo social, algumas abordagens começaram a ser desenvolvidas por grupos de terapeutas de família, na década de 1990. Entre as abordagens mais influentes, encontram-se as chamadas conversacionais e cooperativas, que têm como principais expoentes terapeutas de família como Harlene Anderson, diretora de uma instituição de formação de terapeutas de família, o Instituto Galveston, de Houston, nos EUA; Harold Goolishian, já falecido, que foi Diretor Emérito do Instituto Galveston, e autor de inúmeros artigos sobre terapia de família, muitos dos quais em colaboração com Harlene Anderson; Lynn Hoffman, terapeuta de família e conhecida pela defesa dos novos desenvolvimentos no campo da terapia familiar; e Tom Andersen, psiquiatra e professor de psiquiatria social na Faculdade de Medicina da Universidade de Tromso, na Noruega.

Ao comentarem o processo de desenvolvimento de um novo referencial conceitual que substituísse o antigo empirismo das teorias sobre terapia familiar, Anderson e Goolishian (1998) mencionam que, na busca de uma nova base teórica necessária para fundamentar a prática clínica, desenvolveram uma posição baseada " nos domínios da semântica e da narrativa, e que se apoia principalmente no princípio de que a ação humana acontece em uma realidade de entendimento criada pela construção social e do diálogo" (p.36). Estes autores definem sua abordagem como hermenêutica e interpretativa. Observam que dentre as várias narrativas socialmente originadas que atuam na organização do comportamento, as mais importantes são aquelas que se articulam como autodescrições ou narrativas em primeira pessoa. Tais narrativas ocorrem em um determinado contexto social e local, contando com o envolvimento de outros significativos. É neste processo de conversação e através dele que se desenvolvem as identidades narrativas. É, também, a partir dessas narrativas dialógicas que os indivíduos desenvolvem a percepção de que são capazes de agir socialmente.

A percepção pessoal de competência para ser compreendido, ou para agir, pode ser permitida ou inibida pelas narrativas. Partindo dessas noções, os autores afirmam que os "problemas" apresentados em terapia podem ser entendidos como "resultantes de autodefinições e narrativas sociais que não produzem uma capacidade de ação efetiva para as tarefas implícitas em suas autonarrativas" 
(p.41). Na opinião de Anderson e Goolishian (1998), um problema não é "resolvido" em um processo terapêutico, mas "dissolvido" através de conversações terapêuticas.

A importância da narrativa também é sublinhada por Lynn Hoffman (1998), que, em determinado momento de sua trajetória como terapeuta de família, começou a questionar a objetividade excessiva dos sistemas de crença nos quais as primeiras abordagens de terapia familiar foram baseados. Hoffman comenta a mudança de valorização, ocorrida no século $\mathrm{XX}$ no campo da psicoterapia, da noção de reabilitação para a noção de etiologia. Principalmente influenciada pelos psicanalistas, a valorização de abordagens voltadas para a etiologia dos problemas psicológicos tomou impulso depois da Segunda Guerra Mundial. Conhecidas popularmente por psicólogos americanos como abordagens de "culpa e mudança", essas terapias difundem a idéia de que descobrindo a causa de seus conflitos psicológicos em algo ou alguém, o cliente teria a possibilidade de efetuar mudanças que lhe seriam benéficas.

Famílias disfuncionais, segredos familiares, mitos inconscientes, coalisões, entre outras, apareciam como causas encobertas de problemas, que deveriam ser "descobertas" através dos mais variados modelos terapêuticos. Para a autora, a idéia de que um(a) terapeuta tinha a possibilidade de "modificar" comportamentos externos a ele(a), passou a fazer cada vez menos sentido. Em sua opinião, as abordagens conversacionais e colaborativas, em contraste com as práticas estratégicas nas quais foi inicialmente treinada, estão menos voltadas para a idéia de "cura", e apresentam um grau elevado de preocupação com o sofrimento, honestidade e interesse em relação à narrativa do cliente, além de uma atenção direcionada para sinais de esperança ou de sentimentos positivos. Sinais que apontam para a direção da reabilitação ao invés de para a etiologia dos conflitos. Assim como Anderson e Goolishian (1998), Lynn Hoffman adota a postura do "não-saber", onde o cliente é o especialista. Os resultados terapêuticos provêm das novas narrativas co-construídas por cliente e terapeuta.

Tom Andersen (1998), assim como Lynn Hoffman, passou a questionar a "ênfase hierárquica e intervencionista" dos modelos de terapia de família por ele utilizados. Primeiramente influenciado pelo trabalho da abordagem de Milão, que utiliza o acompanhamento de uma equipe de trabalho que observa a sessão de terapia, protegida por um espelho unidirecional, e faz comentários através de um 
terapeuta que comunica-se com os membros da família, Andersen afirma que sempre sentiu-se desconfortável com este método. Em sua opinião, ao apresentar à família a posição da equipe em relação a seus conflitos, era como se demonstrasse que o terapeuta e sua equipe tinham propostas melhores do que aquelas utilizadas pelos membros da família para lidar com seus problemas. A princípio modificou, apenas, a forma de apresentar as propostas da equipe à família. Passou a utilizar frases como "além do que vocês entenderam, nós entendemos isto" (Elkaïm, 1998, p.72), na tentativa de minimizar a noção de que o terapeuta, como um especialista, tinha as respostas corretas em relação aos problemas daquela família.

Através de discussões com membros de sua equipe de trabalho, o autor acabou por desenvolver o que chamou de Equipe Reflexiva (Andersen, T., 1991). Nesta abordagem os membros da família que participam da terapia, são convidados a participar da discussão da equipe sobre o que foi percebido pelo grupo de terapeutas durante a sessão. Andersen ressalta a atenção que os terapeutas devem ter em relação à linguagem utilizada. Como exemplo menciona que ao convidar a família para compartilhar a discussão com a equipe reflexiva, diz: "Talvez nossa fala traga idéias que podem ser úteis para a sua conversa" (Elkaïm, 1998, p.73).

Estes são apenas exemplos de como alguns terapeutas de família estão lidando com as idéias pós-modernas, afastando-se do referencial sistêmico inicial. São muitas as questões em debate atualmente, entretanto, o que gostaríamos de ressaltar, é a relativização da verdade, do saber, da intervenção do especialista e do modelo de família nuclear. Para ilustrar este debate, apresentaremos a polêmica causada a partir de um artigo de Salvador Minuchin (1998), no qual ele pergunta onde estão as famílias dos terapeutas narrativistas, termo que utiliza de forma generalizada, sem fazer distinção entre os terapeutas que cita.

\section{4}

\section{A Pergunta de Salvador Minuchin}

Após participar de uma reunião de terapeutas de família, onde foram apresentados e discutidos casos clínicos, Minuchin (1998) escreveu o artigo “Onde está a família na terapia narrativa de família?". O artigo evidencia o 
objetivo dos participantes do evento de apresentar e discutir abordagens terapêuticas informadas pelo construcionismo social. Nas palavras do autor, ele e Maurizio Andolfi eram os únicos representantes de uma visão "mais tradicional" de terapia de família presentes ao encontro. Ao longo do artigo, Minuchin questiona se as idéias pós-modernistas, tão prevalentes no campo da terapia de família atualmente, têm alguma relação com o desaparecimento da família do processo terapêutico e justifica seu questionamento através de exemplos dos casos clínicos apresentados. Comenta que, a despeito de estarem debatendo abordagens de terapia de família, nos casos apresentados, apenas um membro de cada família participou da terapia. $\mathrm{O}$ autor descreve sua experiência no evento como "inquietante" e recorre a textos sobre o construcionismo social na tentativa de melhor compreender sua influência nas práticas terapêuticas. Comenta sua simpatia pela postura política presente nas idéias de desconstrução de poder, aceitação das diversidades, entre outras, mas critica a posição que chamou de ideológica em detrimento da prática terapêutica. Indaga qual seria a relação do construcionismo social com a "prática intensamente pragmática de terapia de família" e de que forma essas idéias estariam afetando a visão de família dos terapeutas, assim como o desenvolvimento do próprio processo terapêutico. Os comentários de Minuchin são entremeados por afirmações de teóricos e terapeutas sobre o construcionismo social com as quais argumenta. Afirma que a invisibilidade da família nas práticas narrativas parece-lhe estranha, visto que não encontrou, no construcionismo social, qualquer argumentação que justifique este procedimento. Ao contrário, à medida que a família é o contexto onde "os bebês e as crianças pequenas aprendem sobre si próprias, sobre os outros, sobre crenças do que é real e objetivo e ouvem histórias que colorem suas realidades ", seria esperado que os terapeutas narrativos utilizassem o "laboratório natural de histórias" que é a família.

O autor acrescenta que a focalização na narrativa individual parece ir contra o que dizem os teóricos a respeito do "self" como um construto social. Em sua opinião, a função da família como intermediária desta construção parece ser menosprezada, enquanto as influências de uma cultura maior são privilegiadas. Inúmeras questões são levantadas pelo autor ao longo do texto. Dentre elas indaga se o construcionismo social, “ uma metateoria relacionada à construção da realidade " tem alguma teoria sobre famílias, ou como explica experiências 
familiares como vínculos, alianças entre os membros que criam sub-grupos, ou o bode expiatório. Pergunta, ainda, como seria explicado o fato dos conflitos entre os pais afetarem a visão que os filhos têm sobre si próprios, ou a forma de se lidar com as complexidades da separação conjugal ou do recasamento. A conclusão a que Minuchin chega, sobre essas inúmeras indagações, é que não acredita que uma metateoria, como o construcionismo social, possa ajudar os terapeutas de família a compreenderem o funcionamento familiar, e afirma que isto é motivo de preocupação. Menciona o vasto corpo de pesquisas sobre famílias, nos últimos 40 anos, em áreas diversas como sociologia, antropologia, psicologia, genética, pediatria e outras e pergunta se toda essa diversidade e especificidade pode ser ultrapassada por uma metateoria dita abrangente.

$\mathrm{O}$ autor conclui dizendo que a terapia narrativa afastou-se dos princípios sistêmicos para enfatizar o contexto e a cultura, mas ao longo desse processo os teóricos parecem ter perdido a família - lugar proeminente e intermediário do contexto e da cultura no qual as pessoas vivem - e os terapeutas retornaram à psicologia individual que, além de tradicional, não se encaixa no papel de uma teoria pós-moderna, cuja ênfase é o relacionamento social. Acrescenta que, ao desprezarem as múltiplas vozes no campo da terapia de família, os terapeutas narrativos reforçaram uma voz única, que não reflete totalmente a realidade da experiência humana.

À medida em que o recasamento se apresenta como um afastamento do modelo de família nuclear, a polêmica desencadeada por Minuchin nos parece pertinente para reflexões sobre sua clínica. Na realidade, este debate no campo da terapia de família aponta para uma série de transformações. Entendemos que uma das conseqüências destas transformações é a relativização do modelo de família nuclear.

\section{5}

\section{Respostas à Pergunta de Salvador Minuchin}

O artigo de Minuchin desencadeou uma série de outros artigos de terapeutas de família, alguns citados por ele, que empenharam-se em responder a seu questionamento e debater o que consideraram suposições incorretas sobre as práticas comentadas. Nossa intenção, aqui, não é apresentar todas as respostas na 
íntegra, mas mencionar alguns exemplos que demonstrem as diferenças entre as visões mais tradicionais de terapia de família e as visões chamadas pós-modernas. Em ordem cronológica, a primeira resposta veio de Gene Combs e Jill Freedman, diretores do Evanston Family Therapy Center, em Illinois, EUA. Os autores acolhem as opiniões de Minuchin como mais uma "voz" a contar de que forma o construcionismo social, a narrativa e as idéias pós-modernas têm afetado a prática da terapia de família. Observam que não têm a intenção de provar quem está certo ou errado na argumentação, mas gostariam de esclarecer que não partilham de algumas suposições levantadas por Minuchin. Apontam, como diferença básica entre eles, suas visões de mundo e as suposições que as fundamentam. Como exemplo mencionam a interpretação de palavras como "família".

Citando o artigo de Minuchin, demonstram que, ao falar de família, o autor deixa claro a existência de algo como "a família", que aparece como "natural", comentando que é neste contexto que "os bebês e as crianças pequenas aprendem sobre si próprias, sobre os outros, sobre crenças do que é real e objetivo e ouvem histórias que colorem suas realidades“. Para os autores esta afirmação é uma simplificação de situações complexas, visto que, em sua perspectiva, bebes e crianças aprendem tudo isso em diferentes contextos (hospitais, creches, instituições religiosas, televisão, etc.), não apenas numa "família nuclear idealizada". Os autores prosseguem citando exemplos de suas práticas com diferentes configurações familiares, sublinhando que as definições do que é ou não família podem variar enormemente. Acrescentam que como pais adotivos conhecem as dificuldades potenciais criadas por perguntas sobre os pais "naturais" de uma criança que foi adotada. Acreditam que a linguagem dá forma às percepções de realidade, e expressões como "família natural" ou "família normal" podem levar-nos a considerar configurações familiares diferentes como não naturais ou não normais. Além do mais, suposições como estas, na opinião dos autores, podem impulsionar os próprios terapeutas a guiar as famílias para uma determinada direção, mais "natural" ou "normal". Afirmam que seu interesse como terapeutas, é de multiplicar as possibilidades percebidas pelas famílias e seus membros e não ajudá-los a enquadrarem-se em modelos idealizados.

Através das respostas cuidadosamente elaboradas suscitadas pelo questionamento de Minuchin, podemos perceber o respeito de seus colegas por suas reconhecidas contribuições ao campo da terapia de família. O artigo de 
Carlos Sluzki, psiquiatra, terapeuta de família com inúmeras publicações na área, Diretor do Serviço de Psiquiatria do Santa Barbara Cottage Hospital, na California, evidencia este reconhecimento, ainda que apresente posições diferentes. Com o título "Em busca da família perdida: uma nota de rodapé ao ensaio de Minuchin", Sluzki (1998) argumenta que não se pode atribuir o desaparecimento da família do processo terapêutico ao pós-modernismo. Comenta que, em sua primeira leitura o texto de Minuchin o deixa preocupado, perguntando-se sobre o lugar da família em sua própria prática. Em seguida, faz uma retrospectiva das diferentes posições ocupadas pela família e das diversas atribuições feitas a ela ao longo do tempo, no campo da psicoterapia. Menciona a abordagem estrutural formulada por Minuchin, há 30 anos atrás, como um momento importante de valorização do papel da família pela terapia. De forma clara e concisa, constrói sua argumentação até chegar à valorização da visão contemporânea de um mundo, tal como o conhecemos, co-construído através de consenso. Mostra que esta noção recebeu um grande impulso do construcionismo social, da valorização ou revalorização do papel da linguagem na ordem social e, consequentemente, dos discursos em forma de narrativas. O autor cita Mumby (1993), quando este afirma que:

\footnotetext{
"a narrativa é duplamente um ato socialmente simbólico: a) seu sentido depende de um contexto social e; b) atua na construção deste contexto social como um lugar de sentido no qual atores sociais estão implicados. (...) a ordem social é tênue, precária e aberta a negociações de diversas formas" (Mumby, 1993, apud Sluzki, 1998) ${ }^{*}$
}

Na opinião de Sluzki, a luta constante acerca da predominância de um determinado sentido constitui o campo das políticas interpessoais. O local desta luta é o espaço interpessoal da narrativa, onde um consenso é alcançado, reconfirmado, desafiado e minado através de conversas e ações.

O autor comenta o impacto dessas noções sobre as práticas terapêuticas e afirma que elas podem ter desencadeado uma mudança de nomeação para o campo. Alguns terapeutas de família passaram a definir seu foco e sua atividade como prática sistêmica de segunda ordem (na linguagem cibernética) ou baseada na narrativa (na linguagem pós moderna).

\footnotetext{
* Tradução da autora
} 
Sluzki não nega a importância do contexto familiar onde, segundo ele, grande parte dos humanos são criados e onde a realidade é fortemente definida. É, também, através das interações familiares, suas rotinas, regularidades, lutas e mitos que a ordem social é intensamente influenciada. Por tudo isso, faz sentido, na opinião do autor, que a prática terapêutica privilegie a família quando for possível e apropriado. Entretanto, há outros campos interpessoais onde a ordem social e os sentidos são negociados; na interação com amigos, inimigos colegas de trabalho, professores e alunos, entre outros, além do nosso próprio mundo subjetivo (internalizado). Partindo dessa premissa, as intervenções sistêmicas podem se dar, legitimamente, em outros terrenos, sem que a família seja descartada pela mudança de foco na prática. Adverte, entretanto, para que essas intervenções sistêmicas não sejam nomeadas de terapia de família, para evitar confusões e críticas, como algumas feitas por Minuchin. Observa que a narrativa, como o espaço onde o consenso é desenvolvido e a realidade é construída, mantida ou modificada, oferece um novo foco e uma nova linguagem para uma variedade de práticas. Isto tudo expandiu o mapa do território da terapia de família, que talvez tenha que ter o seu próprio nome reavaliado, visto que a nova abordagem pode incluir práticas de saúde de orientação familiar, terapia individual, mediação, consultoria organizacional, projetos institucionais e terapia de família, para mencionar apenas alguns exemplos.

Sluzki aborda, ainda, duas possibilidades que podem ter contribuído para as críticas de Minuchin às terapias informadas pelo construcionismo social. A primeira diz respeito ao que chamou de "fanatismo inevitável" de defensores de novos pontos de vista que, por vezes, influenciados por forças externas (o poder da propaganda voltado para o lucro de publicações, por exemplo), ou por "estupidez", esquecem que são apenas diferentes pontos de vista. Comenta sobre a importância do terapeuta estar consciente de suas preferências paradigmáticas e conceituais, e de seus preconceitos técnicos, para não "colonizar" as realidades dos pacientes, impondo-lhes seus pontos de vista. O autor acredita que os terapeutas criticados por Minuchin estavam passando por um período de "amor intenso" por seu novo modelo, tornando-se incapazes de perceber a diferença entre "as lentes e o objeto observado". A segunda possibilidade levantada por Sluzki, diz respeito à perda, sofrida pela família, de um lugar privilegiado no processo terapêutico, atribuída ao pós-modernismo. O autor afirma que muitas 
práticas informadas pelo pós-modernismo incluem a família como uma contribuição central ao processo de construção, manutenção e modificação da realidade. Observa, porém, que fatores externos também atuam como variáveis importantes na formatação de uma terapia mais voltada para a responsabilidade individual. Ou seja, a visão interpessoal implica num comprometimento e uma responsabilidade social mais forte. Ao contrário do que aconteceu nas décadas de 1950 e 1960, quando houve uma explosão de novas abordagens psicoterápicas, a década de 1990, nomeada "Década do Cérebro", foi caracterizada pela medicalização do sofrimento emocional, onde genes e neurotransmissores tornaram-se o foco de interesse, enquanto as terapias contextuais e verbais foram relegadas a uma posição marginal. O autor comenta sobre as mudanças de direção das políticas públicas americanas, em relação aos programas comunitários de saúde mental, mencionando fatores como as crescentes indústrias farmacêuticas.

Sluzki conclui seu artigo dizendo que uma pergunta é tão boa quanto as ondas por ela geradas. Admite que, para o bem do campo da terapia de família, as perguntas difíceis e desafiadoras de Salvador Minuchin merecem vida longa.

Karl Tomm (1998) é médico e Diretor do Programa de Terapia de Família do Departamento de Psiquiatria da Universidade de Calgary, no Canada. Seu trabalho também foi comentado por Minuchin, quando este demonstrou estranheza diante de um atendimento apresentado por Tomm, onde apenas um membro da família participou da sessão. Karl Tomm comenta que ao criticar seu atendimento a um único membro da família, Minuchin omitiu dados que informavam que a família recusou-se a comparecer à terapia. Tomm descreve, então, como utilizou o que chamou de "família internalizada" no diálogo com a cliente. $\mathrm{O}$ autor fala sobre os resultados positivos dessa prática, observados por ele um ano depois. Comenta que o artigo de Minuchin traz à tona duas importantes tendências atuais do campo da terapia de família. A primeira diz respeito à relativa mudança de foco dos padrões de interações que ocorrem dentro da família, para um foco sobre os efeitos que as crenças e as práticas culturais exercem nas interações familiares. As suposições culturais sobre as relações entre os gêneros, por exemplo, foram reconhecidas como uma fonte primária de privilégio e dominação masculina nas famílias. A partir desse reconhecimento, maiores esforços terapêuticos têm sido direcionados para ajudar os membros das famílias a liberarem-se dos estereótipos culturais tradicionais, quando esta 
desigualdade entre os gêneros é identificada como fonte significativa de conflitos familiares.

O segundo ponto levantado por Minuchin refere-se à tendência crescente dos terapeutas de família de trabalharem com a história de vida dos indivíduos. Tomm esclarece que os indivíduos costumam atribuir significados idiossincráticos às suas experiências de vida, que são conectadas para formarem histórias pessoais. Esses significados e histórias passaram a ser um foco de intervenção terapêutica, porque acredita-se que eles organizem o comportamento de indivíduos em todas as situações da vida, incluindo suas famílias. Em resposta às críticas feitas por Minuchin, o autor esclarece que, a família não desapareceu da prática clínica, assim como a noção sistêmica de que os membros de uma família co-constróem o sentido, não se perdeu. O que ocorreu, na perspectiva de terapia de família de segunda ordem, foi que a riqueza da terapia sistêmica de família foi estendida e enriquecida pelos desenvolvimentos recentes. Ele afirma que a família ainda é reconhecida como elemento central na mediação dos efeitos de sistemas culturais mais extensos sobre os sistemas individuais menores.

Harlene Anderson (1999) também escreveu um artigo, "Reimaginando a terapia de família: reflexões sobre a família invisível de Minuchin”, motivada pelas indagações e comentários de Salvador Minuchin. Primeiramente a autora afirma que não relaciona sua experiência pessoal com as palavras do autor. Observa que, além de utilizarem linguagens diferentes, partem de premissas diversas, o que inviabiliza a utilização da linguagem de Minuchin para explicar sua posição. Relembra a origem da terapia de família, criada por terapeutas de família como o próprio Minuchin.

As abordagens de psicoterapia familiar utilizadas no tratamento de esquizofrênicos e de famílias de baixa renda, até então, não preenchiam as demandas enfrentadas por esses terapeutas nas instituições onde trabalhavam. Comenta que, embora a terapia de família não seja uma teoria ou uma prática unificada, seu desenvolvimento confrontou suposições básicas nas quais as abordagens individuais eram fundamentadas. Seu desenvolvimento representou uma mudança paradigmática no campo da psicoterapia, que influenciou, consideravelmente, a visão dos terapeutas em relação a todo o processo terapêutico. $\mathrm{O}$ foco do conhecimento e da linguagem psicológicos, antes voltado para os atributos individuais do comportamento humano como um fenômeno 
intrapsíquico, deslocou-se para o contexto local do indivíduo, ou para o sistema de relacionamento interpessoal, que é a família. A família tornou-se o principal foco de indagações, explicações de problemas e o alvo de tratamento. Os terapeutas de família, então, adotaram vários sistemas teóricos e teorias sociais como suas metáforas explicativas.

$\mathrm{Na}$ opinião de Anderson, a terapia de família tem sido freqüentemente identificada com a configuração social que ela expressa, a família, ao invés de ser identificada com a ideologia que reflete, a teoria sistêmica. Este equívoco contribuiu para que a terapia de família fosse designada por alguns como técnica, modalidade ou sub-especialidade, e não como um modo de pensar sobre os sistemas humanos, que informa práticas clínicas. Tais designações perdem de vista ou subvertem a mudança paradigmática inicial, além de reduzirem a noção de terapia de família à mera junção de um grupo familiar como alvo de um tratamento psicoterápico. Afirma que, alguns terapeutas de família, movidos por novas experiências em suas práticas, pelas demandas do mundo contemporâneo e em ressonância com o que chamou de " um rigoroso desenvolvimento intelectual nas ciências sociais (estudos culturais, teoria literária, filosofia da ciência, feminismo, educação e desenvolvimento organizacional, por exemplo) chamado de pós-modernismo", estão buscando novas bases paradigmáticas para suas práticas. Observa que esta nova plataforma, criticada por Minuchin como causa do desaparecimento da família na clínica, é formada pelas terapias pós-modernas colaborativa, narrativa e focalizada na solução.

A autora comenta a afirmação de Minuchin, quando este, referindo-se ao pós-modernismo e ao construcionismo social, diz que "a utilização desta teoria para a compreensão do funcionamento familiar, deverá ser examinada de modo crítico". Sugere que qualquer teoria utilizada para a compreensão do funcionamento familiar seja examinada de modo crítico. Acrescenta que, analisados de um modo geral, o pós-modernismo e o construcionismo social são formas de indagação devotadas ao exame de dois conceitos fundamentais; conhecimento e linguagem. O que sabemos ou pensamos que sabemos, a forma como o conhecimento é criado, o que é privilegiado ou suprimido e o papel da linguagem em todos esses processos, são partes integrantes dessas indagações. Informa que a natureza relacional, dialógica e geradora do conhecimento e da linguagem são perspectivas centrais do construcionismo social. Observa que o 
conhecimento é construído lingüisticamente, que o seu desenvolvimento e transformação são projetos comuns, e que o conhecimento e o conhecedor são interdependentes. A linguagem, falada e não falada, ganha seu sentido pelo uso, e é o principal veículo por nós utilizado para a construção do significado do mundo em que vivemos. Resume dizendo que: "a linguagem é a transformação da experiência e, ao mesmo tempo, transforma o que nós experienciamos". Conclui seu artigo dizendo que o desafio pós-moderno e do construcionismo social, voltados para todas as formas de psicoterapia, não são um modismo passageiro, mas o ponto de mudança para as terapias designadas como colaborativa, narrativa ou focalizada na solução. Cada uma delas tem características distintas, ao contrário do que Minuchin pareceu mostrar em seu artigo, e se estendem para além da noção inicial de terapia de família.

Em uma referência aos títulos das respostas a seu artigo original, Minuchin (1999) encerra o debate por ele criado com um novo artigo, "Recontando, reimaginando e re-pesquisando: uma conversação contínua". Inicia o texto citando Sluzki, quando este diz que "uma pergunta é tão boa quanto as ondas que gera". Considera-se, então, satisfeito pelo número de respostas geradas pela sua questão. Reconhece que "amontoou" diferentes perspectivas sobre pós-modernismo, como apontou Harlene Anderson. Admite que, após a leitura das respostas dos terapeutas, pode perceber uma clara diferença entre suas posições teóricas e práticas. Sua preocupação neste artigo, entretanto, foi de como manter o equilíbrio na tênue linha que separa o diálogo da polêmica. Comenta que decidiu responder os artigos em itens separados, a fim de respeitar os diferentes pontos de vista. Cita comentários específicos, debatendo-os com clareza e convicção. Ao longo do texto relembra sua vasta experiência com famílias de diferentes culturas e de configurações diversas, no intuito de rechaçar o rótulo de terapeuta que trabalha com o modelo idealizado de família nuclear. Menciona o ambiente terapêutico sereno construído por Harlene Anderson, onde parece não haver suicídios, fobias, obsessões, adições ou violência. Indaga-se como a autora passaria do caos ao diálogo sem influenciar a direção da conversação. Descreve sua atuação terapêutica da seguinte forma:

\footnotetext{
"Minha terapia é o encontro ativo entre uma família que precisa da ajuda e um terapeuta especialista, contratado por tempo limitado para dirigir e melhorar a capacidade curativa dos membros da família. O terapeuta tem suas opiniões e tendências e elas tornam-se
} 
explícitas. Ele (a) pode dar suporte, mas pode também desafiar os membros da família a explorarem novos caminhos" (Minuchin, 1999, p.12).

A apresentação detalhada desse rico debate, iniciado por Salvador Minuchin, seria por demais extensa para o objetivo do presente trabalho. Nossa intenção, ao apresentá-lo, foi mostrar que o campo da terapia de família tem a possibilidade de estar inserido num contexto dinâmico de pesquisas, debates de idéias e discussões sobre diversidades, que tornam-se cada vez mais numerosas e acentuadas em nosso mundo contemporâneo. O leitor interessado nos diversos aspectos das terapias de família, sejam eles históricos, ideológicos, teóricos ou práticos, é o grande vencedor deste debate. Resta-nos descobrir, através do trabalho de campo, a posição dos terapeutas de família do Rio de Janeiro em relação ao que foi apresentado até aqui. A seguir teceremos algumas considerações pertinentes ao tema da clínica do recasamento.

\section{6}

\section{Modelos e Terapeutas: A Clínica do Recasamento}

Os temas apresentados nos itens anteriores apontam para uma variedade de teorias e práticas utilizadas pelos terapeutas de família. Pudemos perceber que a diversidade das configurações familiares, assim como um modelo mais tradicional de família, fazem parte das discussões do campo, fora do Brasil. Nossa experiência clínica nos mostra que membros das mais diversas configurações familiares buscam ajuda psicoterápica para seus conflitos. As relações familiares criadas pelo recasamento, colocam a família recasada dentre as configurações familiares não tradicionais. Resta-nos considerar que abordagem teórica e prática melhor se adequaria à clínica do recasamento.

O que percebemos nas discussões entre terapias de família mais tradicionais, ou informadas pelo pensamento moderno e as terapias de família chamadas de pós-modernas, é menos uma discussão sobre técnicas e intervenções que apresentam melhores resultados, e mais uma discussão sobre quem é o terapeuta de família e qual é o seu lugar no processo terapêutico. O lugar do cliente, no caso a família, também é questionado. A posição terapeuta/cliente

\footnotetext{
* Tradução da autora
} 
baseada na visão moderna, está definida. $O$ terapeuta tem assegurada a posição de especialista, que observa as interações familiares e aponta aspectos de uma relação familiar disfuncional que precisam ser modificados. A própria noção de relação familiar funcional traz, embutida, a idéia de um modelo de família. As discussões giram em torno de causas e resultados. Acreditamos que esta posição fica clara através das palavras de Minuchin (1999), citadas no item anterior, acerca de sua prática.

A visão pós-modernista questiona a posição terapeuta/cliente existente. Ao invés da noção de causas e resultados, importada do modelo médico de diagnóstico e tratamento, as diversas abordagens afirmam propiciar novas construções sobre as relações, a auto-imagem e as experiências de vida descritas pelo cliente. Ao terapeuta cabe demonstrar ao cliente sua própria capacidade de fazer novas construções, além de contribuir para que isto aconteça. A configuração familiar, aqui, não obedece a um modelo pré-configurado, visto que a possibilidade de diversidade é, constantemente, considerada. Sluzki (1998) pondera que, as críticas feitas por Minuchin (1998) a esta posição, provavelmente referem-se a situações de aplicação persistente e "teimosa" de uma única metodologia de investigação clínica e de uma adesão forte e "militante" a uma descrição específica e pré-concebida da realidade, a despeito da existência ou não de ressonância por parte do cliente. Acrescenta que essas práticas, ao invés de enriquecerem as experiências de clientes e terapeutas, "achatam a rica textura da experiência terapêutica" (p.416).

Entendemos que, antes de pensarmos sobre uma abordagem teórico-prática adequada à clínica do recasamento, devemos considerar a visão do terapeuta em relação a esse grupo familiar. A criação de qualquer abordagem só poderá se dar a partir desta visão, visto que ela implica na existência ou não de um modelo de família.

$\mathrm{O}$ artigo de Minuchin denuncia o abandono do modelo de família pelos terapeutas narrativos, enquanto que as respostas apontam para a relativização deste modelo.

Através das entrevistas feitas com terapeutas de família do Rio de Janeiro, no estudo de campo, procuraremos investigar, também, se as questões levantadas acima fazem parte de uma discussão local, e de que forma a prática clínica com famílias recasadas é influenciada pelas diferentes posições. 


\section{4}

\section{Pesquisa de Campo}

Como mencionamos na Introdução, três fatores foram determinantes na escolha do tema do presente estudo: 1. a escassez de publicações nacionais acerca da estrutura e da interação familiar dos membros de famílias recasadas, assim como sobre as abordagens psicoterápicas utilizadas para atendê-los; 2. o crescimento constante desse formato de família; 3. o aumento da busca por psicoterapia por membros de famílias recasadas. A partir desses fatores surgiu a questão principal da presente pesquisa, que é verificar, através da prática clínica de terapeutas de família do Rio de Janeiro, qual a percepção desses terapeutas em relação às famílias recasadas e quais as abordagens teórico-clínicas preferencialmente utilizadas em seu atendimento. O que norteia a direção de nossa pesquisa são as seguintes questões relacionadas entre si: Como o modelo de família nuclear influiu e influi na formulação da prática clínica de terapia de família? O recasamento, enquanto desafio a este modelo, representa uma transformação para a clínica? A partir dessas questões, elaboramos o trajeto do presente estudo.

\section{1}

\section{Metodologia}

\subsection{1}

\section{Sujeitos}

A pesquisa de campo foi realizada através de entrevistas com 10 terapeutas de família de orientação sistêmica, do Rio de Janeiro.

A escolha dos sujeitos não implicou em preferência por gênero, faixa etária, ou por vinculação atual a instituições formadoras de terapeutas de família, mas os entrevistados deveriam estar na prática clínica com famílias há, no mínimo, dez anos, em consultórios particulares. Fixamos em 10 anos o limite 
mínimo de prática clínica com famílias, por entendermos que o tempo seria um fator relevante, tendo em vista os objetivos do presente trabalho. A prática clínica em consultório particular foi um critério utilizado para atenuar as variáveis presentes na população alvo atendida pelos terapeutas de família. Entendemos que a população que busca ajuda psicoterápica em consultórios particulares no Rio de Janeiro, pode diferir, em seus universos simbólicos e conjunto de valores, daquela que busca atendimento em outros tipos de instituições

Escolhemos entrevistar sujeitos que trabalhassem com abordagens de orientação sistêmica. Outras orientações teóricas trariam considerações diversas às presentes na literatura por nós analisada.

Nossa intenção inicial foi de compor um grupo de sujeitos que contemplasse, igualmente, terapeutas do sexo feminino e masculino. Entretanto, conhecendo a comunidade de terapeutas de família do Rio de Janeiro, já sabíamos que o número de terapeutas do sexo feminino seria maior do que o do sexo masculino, e que este não poderia ser um critério rígido. Nossa amostra foi constituída por 6 terapeutas do sexo feminino e 4 terapeutas do sexo masculino.

A seleção dos entrevistados se deu através de nosso conhecimento pessoal e de indicações dos próprios sujeitos. Cada entrevistado sugeriu nomes de colegas que poderíamos contatar. É importante ressaltar que os entrevistados foram extremamente cooperativos, abrindo espaço em suas agendas para que pudéssemos entrevistá-los e ajudando no contato com outros colegas.

Ao serem convidados para participar da pesquisa, os sujeitos foram informados do propósito da mesma (estudo de campo para pesquisa de uma tese de doutoramento), assim como do fato de que as entrevistas seriam gravadas e, posteriormente, transcritas. Foram informados também que seus nomes não seriam mencionados ao longo do trabalho.

Todos os entrevistados informaram ter feito algum tipo de especialização na área de terapia de família, através do referencial sistêmico.

A maioria dos entrevistados (oito) já publicou livro ou artigo na área de terapia familiar. Todos já apresentaram trabalhos em congressos, jornadas e encontros de terapeutas de família no Brasil e/ou no exterior.

Cinco dos terapeutas entrevistados têm formação médica. Dois deles informaram que ainda prescrevem medicação, por também trabalharem em instituições para dependentes químicos. Os demais pararam de medicar, 
dedicando-se inteiramente à terapia de família e aos cursos de formação aos quais pertencem.

Oito dos sujeitos entrevistados fazem parte, atualmente, de instituições formadoras de terapeutas de família como professores ou diretores (fundadores). Os dois restantes pertenceram a instituições formadoras no passado.

Quanto ao público predominante atendido pelos terapeutas entrevistados, sete mencionaram o atendimento a casais e três citaram famílias. Quatro dos entrevistados mencionaram uma procura relevante por atendimentos individuais, ressaltando que esses atendimentos geralmente referiam-se a questões relacionais, prioritariamente a questões de parceria.

Optamos por identificar os sujeitos do sexo feminino como TF (terapeuta do sexo feminino) e um número de 1 a 6 , e os terapeutas do sexo masculino como TM (terapeutas do sexo masculino) mais um número de 1 a 4.

São as seguintes as características dos entrevistados:

ENTREVISTADA: TF.1

TEMPO DE TRABALHO COMO TERAPEUTA DE FAMÍLIA: 25 anos. FORMAÇÃO: Psicóloga; psicanalista infantil (formação inicial). ESPECIALIZAÇÃO EM TERAPIA DE FAMÍLIA: Sim. PÚBLICO QUE MAIS ATENDE ATUALMENTE: Casais; adultos com questões em relação à vida amorosa; crises relacionadas à parceria.

ENTREVISTADA: TF.2

TEMPO DE TRABALHO COMO TERAPEUTA DE FAMÍLIA: 18 anos. FORMAÇÃO: Psicóloga; psicanalista (formação inicial). ESPECIALIZAÇÃO EM TERAPIA DE FAMILIA: Sim. PÚBLICO QUE MAIS ATENDE ATUALMENTE: Casais; famílias; adulto individual.

ENTREVISTADA: TF.3

TEMPO DE TRABALHO COMO TERAPEUTA DE FAMÍLIA: 24 anos. FORMAÇÃO: Psicóloga; Mestre em psicologia; psicanalista (formação inicial). ESPECIALIZAÇÃO EM TERAPIA DE FAMÍLIA: Sim. 
PÚBLICO QUE MAIS ATENDE ATUALMENTE: Casais; adulto individual (3 ${ }^{\mathrm{a}}$ idade).

ENTREVISTADA: TF.4

TEMPO DE TRABALHO COMO TERAPEUTA DE FAMÍLIA: 14 anos.

FORMAÇÃO: Neuropsiquiatra infantil; psicanalista (formação inicial); mediadora.

ESPECIALIZAÇÃO EM TERAPIA DE FAMÍLIA: Sim.

PÚBLICO QUE MAIS ATENDE ATUALMENTE: Relações; famílias.

ENTREVISTADA: TF.5

TEMPO DE TRABALHO COMO TERAPEUTA DE FAMÍLIA: 18 anos.

FORMAÇÃO: Psicóloga; Mestre em serviço social; doutoranda em psicologia . ESPECIALIZAÇÃO EM TERAPIA DE FAMÍLIA: Sim.

PÚBLICO QUE MAIS ATENDE ATUALMENTE: Casais.

ENTREVISTADA: TF.6

TEMPO DE TRABALHO COMO TERAPEUTA DE FAMÍLIA: 18 anos.

FORMAÇÃO: Psicóloga; Mestre em psicologia clínica; psicanalista (formação inicial).

ESPECIALIZAÇÃO EM TERAPIA DE FAMÍLIA: Sim.

PÚBLICO QUE MAIS ATENDE ATUALMENTE: Famílias; adulto individual.

ENTREVISTADO: TM.1

TEMPO DE TRABALHO COMO TERAPEUTA DE FAMÍLIA: 14 anos.

FORMAÇÃO: Psicólogo; psicanalista (formação inicial).

ESPECIALIZAÇÃO EM TERAPIA DE FAMÍLIA: Sim.

PÚBLICO QUE MAIS ATENDE ATUALMENTE: Casais; famílias.

ENTREVISTADO: TM.2

TEMPO DE TRABALHO COMO TERAPEUTA DE FAMÍLIA: 19 anos.

FORMAÇÃO: Psiquiatra; psicanalista (formação inicial).

ESPECIALIZAÇÃO EM TERAPIA DE FAMÍLIA: Sim.

PÚBLICO QUE MAIS ATENDE ATUALMENTE: Famílias; casais. 
ENTREVISTADO: TM.3

TEMPO DE TRABALHO COMO TERAPEUTA DE FAMÍLIA: 25 anos.

FORMAÇÃO: Psiquiatra; psicanalista (formação inicial).

ESPECIALIZAÇÃO EM TERAPIA DE FAMÍLIA: Sim.

PÚBLICO QUE MAIS ATENDE ATUALMENTE: Adulto individual; famílias de dependentes químicos.

ENTREVISTADO: TM.4

TEMPO DE TRABALHO COMO TERAPEUTA DE FAMÍLIA: 20 anos.

FORMAÇÃO: Psiquiatra; psicanalista (formação inicial).

ESPECIALIZAÇÃO EM TERAPIA DE FAMÍLIA: Sim.

PÚBLICO QUE MAIS ATENDE ATUALMENTE: Casais.

\subsection{2}

Instrumento

O instrumento selecionado para empreender a pesquisa de campo foi a entrevista com roteiro. Este instrumento permite que a entrevista seja orientada por tópicos, que são introduzidos pelo entrevistador, sem que uma ordem rígida tenha que ser seguida. Esta forma, já utilizada pela autora em trabalhos anteriores, permite que entrevistado e entrevistadora mantenham uma postura mais informal, semelhante a uma conversa.

A entrevista foi dividida em três tópicos: o primeiro refere-se a informações sobre o terapeuta e sua clínica. Neste tópico o entrevistado pôde falar sobre sua formação e sobre o seu trajeto profissional, além de informar sobre o público que atende. Foi o espaço da entrevista utilizado para que o entrevistado definisse família e discorresse sobre a possível influência de suas experiências pessoais em sua prática clínica.

$\mathrm{O}$ segundo tópico refere-se, especificamente, ao recasamento. $\mathrm{O}$ entrevistado pode apresentar sua percepção sobre famílias recasadas, sua experiência clínica com este formato de família e suas considerações sobre queixas e especificidades dos membros das famílias recasadas.

As abordagens teórico-clínicas utilizadas pelos entrevistados foi o tema principal do terceiro tópico do roteiro de entrevistas. Neste tópico também 
abordamos o interesse dos entrevistados por pesquisas relacionadas ao recasamento, assim como comentários sobre seus autores favoritos.

\subsection{3}

\section{Procedimentos}

$\mathrm{Na}$ etapa inicial da pesquisa fizemos uma revisão da literatura, com o intuito de abrangermos o percurso e as transformações sócio-históricas do modelo de família nuclear. Fizemos também uma revisão bibliográfica, através de pesquisas teórico-clínicas, sobre as relações familiares no recasamento e sobre a percepção social e terapêutica relacionada a esta configuração familiar. Estendemos a revisão da literatura ao campo da terapia de família, na qual buscamos fazer um breve mapeamento das transformações ocorridas entre o início desta prática e o contexto atual do campo.

Para a contextualização sócio-histórica do modelo de família nuclear moderna, modelo este de influência determinante nas formulações teóricas iniciais de terapia de família, utilizamos autores do campo da sociologia e da história da família.

A maioria dos autores das pesquisas sobre recasamento por nós utilizadas, são terapeutas de família, radicados nos Estados Unidos, provenientes de orientação sistêmica. Nossa escolha deveu-se, prioritariamente, ao volume e a variedade de publicações sobre tema, ao qual temos maior acesso.

Nossa revisão bibliográfica na área de terapia de família priorizou autores que escrevem sobre a história da terapia de família e fazem uma análise comparativa das diversas abordagens deste campo. Em relação à Terapia de Família Estrutural e às abordagens denominadas de pós-modernistas, buscamos maiores subsídios em artigos diversos, publicados em revistas especializadas.

Após a realização da revisão da literatura sobre os temas a serem pesquisados, direcionamos nossa atenção para o estudo de campo. Primeiramente desenvolvemos os critérios para a escolha dos sujeitos, já mencionados anteriormente. Posteriormente, visando aprimorar o instrumento de pesquisa, demos início às entrevistas-piloto. Foram realizadas duas entrevistas com terapeutas de família, para verificarmos se os objetivos da pesquisa seriam alcançados através da utilização do roteiro de entrevista elaborado. A partir dos 
dados obtidos nas entrevistas-piloto, observamos que poderíamos tratar com mais objetividade a parte referente às informações sobre a formação dos entrevistados, que não pareciam acrescentar dados relevantes ao estudo. Os temas inicialmente propostos foram mantidos.

$\mathrm{Na}$ etapa seguinte do trabalho, demos prosseguimento à pesquisa de campo, através das entrevistas com terapeutas de família do Rio de Janeiro. Nosso principal objetivo foi verificar, a partir das respostas dos entrevistados: o modelo de família que influenciava suas práticas clínicas, a percepção de cada sujeito sobre o recasamento e suas relações familiares, e a abordagem teóricoclínica utilizada no tratamento de membros de famílias recasadas. Procuramos identificar a posição dos terapeutas de família por nós entrevistados acerca dos aspectos acima mencionados, visto que a revisão da literatura apontou para uma relação estreita entre eles.

\section{2}

\section{Análise e Discussão das Entrevistas}

\subsection{1}

\section{Temas e Categorias de Análise}

Os temas abordados nesta pesquisa foram selecionados a partir da revisão da literatura, sendo norteados pelo roteiro elaborado para as entrevistas. As categorias de análise foram constituídas a partir das entrevistas realizadas. Elas se inserem em três temas devido a sua relevância para os objetivos do presente estudo: 1. concepções do terapeuta; 2. especificidades do recasamento; 3. referências teórico-clínicas.

Embora a expressão "concepções do terapeuta" possa implicar na idéia de uma abrangência muito ampla, nossa intenção é que ela se limite às concepções do terapeuta em relação ao modelo de família, à família recasada e às transformações sociais que se refletem em sua prática clínica. As concepções do terapeuta em relação ao modelo de família não só estão estreitamente relacionadas com as intervenções terapêuticas, como também as determinam (Ponciano, 2002). As transformações sociais, como foi observado ao longo do trabalho, refletem-se na prática clínica. O modo como o terapeuta percebe tais 
transformações e lida com elas poderá influenciar suas intervenções terapêuticas e, algumas vezes, o próprio referencial teórico que as fundamenta. Três categorias de análise relacionam-se a este tema: 1. família; 2. família recasada; 3. transformações sociais.

O tema "especificidades do recasamento" refere-se à percepção do terapeuta em relação às especificidades das famílias recasadas. A própria visão do entrevistado a respeito da existência ou não de uma clínica específica do recasamento, relaciona-se a este tema. A categoria "queixas relacionadas ao recasamento" refere-se a ele.

O tema "referências teórico-clínicas" diz respeito às teorias que informam a prática clínica do terapeuta, os autores cujos trabalhos o influenciam, assim como seu interesse e conhecimento acerca de pesquisas sobre o recasamento. Denominamos de "relação teoria-prática" a categoria de análise referente a este tema.

\subsection{2}

\section{$1^{\text {a }}$ categoria: Família}

A categoria família refere-se não apenas ao modelo de família que o terapeuta traz para a sua prática clínica, mas indica a definição de família por ele elaborada. Nossa intenção, ao propor esta categoria, é verificar a influência do modelo de família nuclear na concepção de família do terapeuta e, consequentemente, na abordagem clínica por ele utilizada.

Ao analisarmos as entrevistas encontramos uma aparente diversidade nas respostas, o que nos fez refletir sobre a possibilidade de compará-las. Após repetidas leituras começamos a perceber algumas semelhanças que pareceram relevantes. A primeira delas foi o fato de dois sujeitos comentarem sobre a complexidade da própria pergunta. Visto que estávamos entrevistando terapeutas de família, e a pergunta referia-se à definição de família, parecia, no mínimo, intrigante a dificuldade ou complexidade mencionada por eles Optamos, assim, em relação às categorias família e família recasada, em apresentar suas definições literais. Nas palavras de dois entrevistados: 
"Essa é uma pergunta para 300 livros! Eu vou tentar resumir, mas essa pergunta é altamente complexa hoje. É tema de uma conferência. Família hoje abre chave : desde a família nuclear regularmente constituída, e família, é sempre bom reafirmar, é com o nascimento do filho que começa o núcleo familiar, passando pelas famílias ... pessoas que moram juntas e não foram legalmente casadas, nada contra, pai, mãe, filhos, famílias uniparentais, sejam constituídas desde o início na uniparentalidade, famílias uniparentais pós-divórcio. Famílias recasadas, famílias homossexuais, que estão aparecendo muito hoje, tanto masculino como feminino. Famílias adotivas, apesar que não se usa muito porque depois que adota vira como uma família, mas eu diria que teria a marca da adoção. É ampla ..." (TM.2).

"Pergunta difícil. Hoje em dia a gente ... o conceito de família tradicional mudou muito ... a gente trabalha aqui na Teoria Geral de Sistemas, então a gente entra num sistema que a família traz ... eu vou trabalhar com aquilo que vem, que chega” (TM.3).

Evidencia-se, pelas respostas dos sujeitos, uma dificuldade em definir família, relacionada à variedade de modelos de famílias existentes ou socialmente aceitos hoje em dia.

Na resposta de TM.2 podemos perceber a ênfase na reafirmação de que a família só é considerada como tal a partir do nascimento do filho. Este fato caracteriza o modelo de família nuclear, com o qual o entrevistado também inicia sua descrição das possíveis configurações familiares.

Assim como TM.3, outros entrevistados também mencionaram a percepção de família originada pela experiência clínica ou pelo referencial teórico adotado. Mostraram que o modelo de família nuclear está presente em suas considerações:

\footnotetext{
“... aí eu não consigo fugir à teoria ... realmente a família é mais do que ... é um todo, que é mais do que a soma das partes. Isso para mim não é teoria. Em termos de consultório, são as pessoas envolvidas na dinâmica da família ... a base do atendimento é pai, mãe e filhos" (TF.2).
}

“Geralmente, quando vou atender uma situação de família, peço para quem está me ligando para ela definir quem são as pessoas que estão envolvidas naquela situação problema que ela esta me trazendo ... deixo um pouco para a própria pessoa definir qual é o sistema que está envolvido naquela situação. Acho que meu olhar hoje está muito mais para o sistema envolvido na situação problema do que propriamente ... família, no sentido de estar demarcado ... laços consangüíneos" (TM.1).

Após mencionar a família como a "situação-problema", referindo-se àquela família que busca ajuda psicoterápica, TM.1 acrescenta:

"Em termos de definição eu diria que ... seriam as pessoas que têm uma história de convivência, quer dizer, pessoas significativas para aquelas pessoas, ou que tenham uma história de convivência ... Hoje em dia não dá mais para ter um modelo” (TM.1). 
“...aquelas pessoas que se constituem, dentro daquele espaço geográfico, e se denominam uma família ... se estou atendendo uma família que, por qualquer situação social ou familiar, moram duas tias velhas, uma mãe idosa, mãe, três filhos e um monte de sobrinhos, é essa a família que eu vou olhar. Quem eu imagino que seja a família nuclear, quem eu chamo para a consulta, é aquela família que mora junta” (TF.6).

Embora TF.6 tenha afirmado que considera uma família aquelas pessoas que co-habitam e que se denominam como tal, referiu-se à família nuclear como um modelo bastante presente:

"Mesmo que um pai esteja ausente, tem o imaginário ali ... existe um pai. Acho que a gente ainda lida com esse conceito mais tradicional de família, pai, mãe e filhos. (...) Mas o modelo de família nuclear, aquele modelo que existe um pai, existe uma mãe e existem filhos, nem que seja até no sentido biológico, este modelo está presente" (TF.6).

\title{
Diferentemente do modelo descrito pelo sujeito acima, uma das entrevistadas baseou sua definição de família muito mais em palavras que denotam sentimentos relacionados à família do que em algum tipo de configuração familiar mais objetiva:
}

\begin{abstract}
"Eu acho que a família é algo que passa pelo afeto, pela idéia de cumplicidade, de cooperação de ... embora carregada, às vezes, de emoções, que eu chamaria de afetos, mas afetos muito negativos. Tem uma relação muito forte com outro tipo de afeto, que é a esperança ... tem um certo aprisionamento no vínculo. Não é um afeto como amizade ... permanece com uma história que atravessa mais de uma geração. A família tem uma série de componentes que não são só pessoas, mas de tempo, de culturas que vão formando um território muito singular" (TF.1).
\end{abstract}

Percebemos que a entrevistada tenta elaborar uma definição que não se prende a um modelo específico de família, mas remete a características que seriam universais. Ao falar sobre a influência do vínculo biológico, porém, aponta para um modelo que seria relevante para as pessoas que atende. Em suas palavras:

\footnotetext{
"Eu acho que o biológico, na cultura ocidental, dá um lugar de pertinência diferente. Nós que estudamos as famílias, percebemos que elas vão se armando como um mosaico, com as mudanças de divórcio, mudanças de parceiros, e os irmãos, os descendentes ou os ascendentes que têm vinculação sangüínea, se comportam com mais comprometimento com a idéia de família do que aqueles que não têm. (...) Na maior parte das experiências que tive com famílias, o vínculo sangüíneo ocupa um lugar de importância” (TF.1).
} 
Compartilhar afeto foi uma das características mencionadas na definição de família de TF.3. A entrevistada enfatizou também a noção de um projeto comum como um traço relevante deste grupo:

“...é um grupo de pessoas, que estão juntas com um projeto, que compartilham afeto, que interagem ... que têm um projeto comum. Não posso dizer eles têm a mesma consangüinidade, porque no recasamento não há, e não deixa de ser uma família” (TF.3).

Uma outra entrevistada agrupou, em sua definição, muitos dos elementos mencionados de forma isolada pelos outros sujeitos, enfatizando a tendência à relativização da idéia de família, percebida em grande parte das definições.

\footnotetext{
"Um grupo de pessoas que convive, ou por laços de sangue, ou por determinação histórica, ou por escolha, ... que mantém uma convivência ... ou por determinação histórica ou por escolha. E que atribuem às relações um parentesco, porque você pode ter duas amigas morando juntas, só dividindo um apartamento, mas você pode ter duas mulheres morando juntas com a intenção de serem um casal. Então acho que também tem a intenção ... funcional ... da relação. Não sei se esta é uma boa palavra ... . Tem também a descrição das pessoas sobre que relação elas estão estabelecendo, esse é meu pai, esse é meu filho, independente de não ser o pai biológico, essa é minha mulher, independente de haver um casamento legal" (TF.4).
}

Podemos perceber que a entrevistada não fundamenta sua definição de família num modelo determinado. Parte da idéia da convivência entre pessoas, que pode ser desencadeada por razões tão diversas como determinação histórica, escolha ou por laços de sangue. As relações entre essas pessoas são intencionais, auto-atribuídas e auto-denominadas. É uma definição que contempla a diversidade familiar mencionada na literatura de orientação pós-moderna.

Enquanto TF.1, mencionada acima, definiu família através dos sentimentos que a caracterizam, TF.5 baseou sua definição nos deveres familiares. Considerou a família como um desafio, visto que seus criadores têm a responsabilidade de garantir o bem estar de todos:

“... é um conjunto de pessoas que escolheu ... alguns escolheram ficar juntos, para formar essa família, e que geraram outras pessoas, e que tem uma responsabilidade imensa de garantir o bem estar de todos os seus membros, o que é um desafio ... a família para mim é um desafio. A primeira escolha, o teu parceiro, não é biológica. A partir do momento que você tem filhos, gera um vínculo ... que tem muito de biológico ... não sei o quanto que ... no meu caso é todo biológico, mas eu não sei como seria se não fosse biológico" (TF.5). 
A entrevistada prossegue descrevendo sua própria família. Ao comentar que não sabe como seria se não fosse biológico, aponta para a sua percepção de um modelo de família ideal, calcado nos laços sangüíneos. Em nosso entender, este ideal coloca as famílias recasadas ou aquelas com fillhos adotivos na direção oposta.

A despeito das diferentes nuances que identificamos nas respostas dos entrevistados, foi possível perceber que alguns são bastante influenciados pelo modelo de família nuclear, próprio da modernidade, enquanto outros desprenderam-se ou tentam desprender-se deste. Quando dizemos que alguns tentam desprender-se, estamos baseando nossa opinião nas palavras dos próprios entrevistado. Enquanto TF.4 elabora uma definição de família calcada na ausência de modelos, outros citam a grande diversidade de famílias que atendem hoje em dia. Apresentam, entretanto, suas opiniões pessoais a respeito do que consideram uma família, realçando o modelo nuclear determinado pelo vínculo biológico:

\footnotetext{
“O meu self diz que família é uma mãe e um pai com filhos, e que ficam juntos até esses filhos ficarem livres e saírem. Mas isso é dentro dessa família, como foi a minha. Atualmente não é isso que eu vejo. Vejo que há outros tipos de famílias, que elas são válidas e funcionam muito bem. $\mathrm{O}$ que eu gosto muito de frisar, e pouco me importa se isso é polêmico ou não, é que uma família uniparental, que é só uma mãe, na maioria das vezes, é diferente de uma família com mãe e pai. Uma família de lésbicas é diferente de uma família heterossexual, uma família de homossexuais também. Para mim não tem esse negócio de dizer que é igual. Não é verdade. Se fosse igual, ninguém discutiria. Eu acho que pode ser equivalente, pode ser tão eficiente uma quanto a outra, mas dizer que é igual eu não acho. Do mesmo jeito que eu não acho que filho adotivo é igual a filho de barriga" (TM.4).

“... de uma certa maneira, mesmo que a gente queira ser moderno, no sentido de considerar que a família não é mais aquele padrão, ela tem essa questão. Os fillhos, para nascerem, precisam de um homem e de uma mulher. Daqui a pouco nem vão precisar mais, mas de certa forma ainda precisam do gameta..." (TF.6).
}

As falas desses entrevistados nos fazem refletir sobre algumas questões. Primeiramente, parece que tornou-se "politicamente incorreto", no campo das terapias, qualquer tipo de comentário que pareça excluir algum grupo da possibilidade de considerar-se família, com todos os direitos, deveres e características a ela atribuídos. Os entrevistados mencionam expressões como "polêmicos" ou "não moderno" antes de expressarem suas opiniões pessoais sobre o tema, como se as considerassem ultrapassadas. Acreditamos, porém, que 
a interpretação feita por alguns profissionais sobre a obrigatoriedade de inclusão de uma variedade de modelos na definição de família, esteja distorcida por um mandato pós-moderno de relativização, ao qual aderem com contradições.

Verificamos, a partir de nossa breve revisão da literatura, que há críticas e tentativas de mudança, por parte dos terapeutas e estudiosos do tema, em relação à chamada "ideologia da família nuclear". Levin (1997) afirma que utilizamos o modelo de família nuclear como um código ideológico, que em analogia a um código genético, "reproduz suas formas características e sua ordem em múltiplos e variados ambientes discursivos" (p.123). A autora observa que há uma comparação constante entre a família nuclear e outras configurações familiares, que são sempre vistas como alternativas deficientes. $\mathrm{O}$ que é proposto não é o abandono do modelo de família nuclear que, na opinião de Ponciano (2002), esteve, e continuará presente em nossa sociedade, mas que se reflita sobre a presença deste ideal ou sobre a ideologia a ele atrelada. A direção apontada pela literatura parece ser no sentido de ampliar as definições. Desta forma, as diferentes configurações familiares poderão ser socialmente aceitas, além de contempladas pelas políticas públicas (direitos que dizem respeito à utilização dos serviços públicos por membros reconhecidos daqueles grupos familiares, por exemplo).

Percebemos, através das respostas dos entrevistados, que as definições de família seguiram três direções. Alguns sujeitos apontaram para o modelo de família nuclear moderna de forma explícita. Outros o fizeram através de comentários, embora tenham mencionado que a família é aquela que se nomeia como tal na clínica. Um terceiro grupo demonstrou uma relativização quanto ao modelo de família, mencionando intencionalidade, auto-nomeação, projeto comum, sentimentos, sem enfatizar questões como fatores biológicos ou, até mesmo, o gênero dos parceiros em suas definições. Em muitos momentos ficou evidente que havia uma definição de família, já implícita no referencial teórico mencionado pelo entrevistado, seguido de uma relativização baseada na prática clínica. Quando um dos entrevistados observa que "a gente entra num sistema que a família traz ... eu vou trabalhar com aquilo que vem, que chega" (TM.3), ele está verbalizando a contradição entre o que é considerado família na teoria sistêmica, e o que aparece em sua clínica. 
TM.3, assim como outros entrevistados, menciona Minuchin como um dos autores que influenciam o seu trabalho clínico. Minuchin (1990a) descreve claramente as funções e tarefas de famílias "normais", que se adequam ao modelo de família nuclear. Analisemos alguns exemplos:

\footnotetext{
"A família é uma unidade social que enfrenta uma série de tarefas de desenvolvimento. Estas diferem junto com parâmetros de diferenças culturais, mas possuem raízes universais" ( Minuchin, 1990a, p.25).

“Os Wagner, na entrevista que se segue, constituem uma família comum, isto é, o casal tem muitos problemas na relação de um com o outro, na educação dos filhos, em tratar com parentes afins e em enfrentar o mundo exterior. Como todas as famílias normais, eles estão constantemente lutando com esses problemas e negociando os compromissos, que tornam possível uma vida em comum” (Minuchin, 1990a, p.25).
}

Existe uma noção clara de família comum ou normal nas citações acima. Problemas e tarefas são mencionados, mas são bastante previsíveis, sobrando pouco espaço para diferenças. Uma certa contradição se instala, à medida que os entrevistados aderem, pessoalmente, a esse modelo teórico. Vêem-se, assim, obrigados a assumir uma posição de relativização dessas noções, em virtude de uma realidade diversa que surge na prática clínica.

\subsection{3}

\section{$2^{\mathrm{a}}$ categoria: Família recasada}

Esta categoria refere-se à percepção do entrevistado em relação à família recasada, assim como à sua definição sobre este grupo. Pretendemos também verificar quais os paralelos, as diferenças e as comparações feitas ou sugeridas pelo entrevistado em relação à sua concepção de família de primeiro casamento.

Perguntamos aos entrevistados o que seria, para eles, uma família recasada ou, como eles definiriam uma família recasada. Assim como na $1^{\text {a }}$ categoria, "família", nos deparamos com dificuldades ao tentar agrupar semelhanças entre as respostas. No nosso entender, apenas um dos entrevistados colocou em sua definição todos os aspectos que compõem a noção de uma família recasada, conforme descrita na literatura. Em suas palavras:

“...aquela que um dos parceiros adultos, um dos parceiros do que seria o casal, ele tem ou ela tem uma experiência de casamento, de vínculo afetivo anterior a esse casamento, e 
trouxe para essa relação filhos, que moram juntos ou não, mas que têm uma relação em que alguém é biologicamente progenitor e alguém não é ...” (TF.1).

A literatura especializada nos mostra que os filhos de uma relação anterior de um dos membros do casal constituem uma das características marcantes da família recasadas. Gamache (1997) afirma que, de acordo com a opinião de outros pesquisadores, os filhos são os laços sem os quais as famílias recasadas não existiriam. Eles são, na maioria das situações, uma espécie de "documentação" constante e objetiva da existência de uma relação conjugal prévia. Representam, também, a responsabilidade parental criada em um momento anterior, que é trazida para a nova família. Dentre os entrevistados, três não mencionaram filhos em suas definições, e um mostrou incerteza se a existência de filhos caracterizava a família recasada. Comparemos suas palavras:

\footnotetext{
"Eu acho que uma família de recasamento é uma família que viveu uma relação ... podese dar o nome de casamento, uma relação intensa, de estarem compartilhando, terem projetos e tal... e se separam e um dos elementos tem uma nova relação. Isso para mim é um recasamento, não precisa ter nenhuma obrigatoriedade legal ...” ( TF.3).

"Eu acho que duas pessoas, em que pelo menos uma delas já tivesse tido uma vivência anterior que nomeou de relação de casamento, e que ... perde essa relação por natureza diversa, e inaugura uma segunda relação que nomeia de relação de parceria, de casamento. Desde que uma delas tenha vivido esta situação, eu considero que é uma situação de recasamento" ( TF.4).
}

É importante ressaltar que, numa entrevista na qual é criado um tom de informalidade, e onde as perguntas não são previamente conhecidas, não esperamos que o entrevistado estruture uma definição formal, do tipo esperado em um trabalho escrito, por exemplo. Muitas vezes, falas que fizeram sentido no momento de sua enunciação, parecem confusas ao serem transcritas. Nossa intenção quanto à análise, portanto, focaliza-se no conteúdo dessas respostas.

Observando o conteúdo das duas respostas acima, podemos perceber que as definições do que é recasamento, assim como do que é casamento, são demasiadamente amplas. A existência de filhos de relações anteriores não é mencionada. Os filhos também não estão presentes nas duas respostas abaixo, embora TF.5 tenha demonstrado dúvidas quanto a considerar recasamento uma união sem filhos. 
"Uma família reconstituída ... seria uma família na qual um dos dois já teve alguma experiência de união anterior, mesmo sem filhos ... eu acho que tem ... principalmente que um ou outro tenha um filho ou não, mas eu acho que um recasamento, mesmo uma segunda relação que tenha tido algum nível de estabilidade, já é um recasamento ..." (TF.5).

“...uma família recasada foi ou alguém que ficou viúvo, ou alguém que se divorciou que, de repente, encontrou o outro alguém, que é pela primeira vez, ou é divorciado, ou que é viúvo também. E que essa pessoas já tem ... recordações outras, na hora que eles entram numa relação, e que isso interfere muito nessa nova relação. Que quando você casa a primeira vez, você sai de casa, você tem aquele modelo de pai e mãe, que você quer fazer exatamente o contrário, ou igual ... mas quando você está num recasamento, você tem esse problema e tem mais as memórias e recordações desse primeiro ou segundo casamento. Isso vai influenciar nesse seu segundo recasamento" (TM.4).

A resposta de TM.4, não menciona a existência de filhos, e mostra uma outra característica presente em algumas definições de família recasada, que é a existência de dificuldades ou problemas considerados inerentes a esse grupo familiar.

TM.4 fala sobre a influência de recordações e memórias passadas no recasamento. Embora o entrevistado não tenha especificado a natureza dessas recordações e memórias, ou que tipo de influência elas poderiam ter numa nova relação, sua descrição demonstra a existência de um parâmetro, ao qual a nova relação será comparada.

Em um artigo onde aborda as suposições e preconceitos presentes nas pesquisas sobre recasamento, Gamache (1997) observa que os pesquisadores estão inseridos numa cultura que posiciona a família nuclear como parâmetro ideal, ao qual todas as outras configurações familiares são comparadas. A autora observa que, o uso contínuo do "mapa da família nuclear" nos temas relacionados à família, além de mascarar características específicas da família recasada, dá lugar ao surgimento de falsas representações desta família na literatura especializada.

Dois outros entrevistados apontam para características que indicam fragilidades e problemas associados às suas definições de recasamento. Analisemos outras definições:

\footnotetext{
"Primeiro eles têm que se nomear assim, se descrever como família recasada. A descrição deles é fundamental, mais do que a minha, lógico. Eles se nomeiam, mas eu acho que tem que ter uma base na realidade. Não precisa ser casado, eles podem ter tido, antes, companheiros ... eu acho que é o mais alto nível de complexidade que uma família pode viver são famílias recasadas, com filhos anteriores ao casamento. (...) é uma coisa óbvia para a gente, mas para o casal, eles não sabem que eles carregam isso" (TF.2).
} 
“... na hora que o homem deixa ... sai de uma relação e investe numa outra, ele, de uma certa forma, já tem uma bagagem. Se ele casa com uma mulher que nunca casou, ele leva essa bagagem para a relação, mas se essa mulher também teve uma história de casamento que se desfez, ela também traz sua bagagem de casamento. Mas eu vejo que no recasamento, as pessoas trazem suas histórias vividas com outro parceiro, e que geralmente se repetem ..." (TF.6).

Ao definir uma família recasada, TF.2 enfatiza as dificuldades inerentes a esta configuração familiar, comentando que a própria família não se dá conta que essas dificuldades provêm do recasamento.

A resposta de TF.6 refere-se à separação conjugal e ao início de uma nova relação como uma iniciativa masculina. Achamos importante registrar que não foi investigado, como seria desejável, se a entrevistada acredita que a separação e os recasamentos partam dos homens, se esta é uma peculiaridade do Rio de Janeiro, ou se foi força de expressão.

TF.6 acrescentou comentários à sua resposta, que remeteram a pesquisas americanas recentes que indicavam que um primeiro casamento tinha $50 \%$ de chances de acabar em separação e que "a chance de um recasamento fracassar é de 65\%". Observa que "a chance de um segundo casamento repetir, com tempero, o que aconteceu no outro ... está levando os casais a repensarem esta possibilidade...". A entrevistada acrescenta, contudo, que as repetições não se dão exatamente da mesma maneira, visto que há outras pessoas envolvidas. Sua resposta aponta para duas características do recasamento: o fracasso ao qual, de acordo com a pesquisa, a maioria está fadada, e o envolvimento de muitos personagens compondo histórias que podem ter finais imprevisíveis. Estas duas características são indicativas da dificuldade de definir o recasamento de uma forma positiva, considerando, também, a constituição de um primeiro casamento como mais marcante para os personagens envolvidos. $\mathrm{O}$ fragmento seguinte demonstra uma tentativa de dar uma definição ampla, que parece querer resolver esta dificuldade:

"Para mim, um casamento ou um recasamento é quando duas pessoas resolvem, a partir de um projeto juntos, montar aquele espaço ... e o espaço é geográfico, são as paredes, as fronteiras, enfim, é o sistema...” (TF. 6). 


\title{
Indagada sobre a existência de filhos em sua idéia de recasamento, a entrevistada TF.6 evidenciou mais um aspecto negativo, gerador de conflito, para o recasamento:
}

\begin{abstract}
"Claro, os seus, os meus e os nossos ... e aí vêm muitos conflitos. Eu trabalho com muitos casais que ao se casarem, se deparam com os filhos do parceiro, e se sentem na obrigação de amá-los, mas a maioria não os ama, nesse sentido, aprende a suportar ... a conviver (...) Outros podem até pensar em adotar, mas eu acho que aí é mais uma briga de poder ... eu vou adotar o filho do seu ex-marido, que não dá bola, não da pensão, para provar que sou capaz de sustentá-lo e tal. Mas eu acredito que a relação pode ser construída, principalmente se essas questões forem abordadas. Se o amor for obrigatório e um ou outro se sentir obrigado a amar o filho do outro, só porque estão casando, já fica complicado. (...) Você pode amar o filho do seu marido se você puder até não amar, mas se você for cobrada, já começa a ficar complicado“ (TF.6).
\end{abstract}

Definições de famílias recasadas que já incluem descrições de problemas, conflitos e fragilidades relacionais, parecem apontar para as expectativas pouco otimistas do entrevistado em relação a esse grupo familiar.

Coleman, Ganog e Fine (2000) observam que as pesquisas desenvolvidas na década de 1980 sobre o tema, preocupavam-se em descrever as dificuldades e conflitos enfrentados pelas famílias recasadas. $\mathrm{Na}$ opinião dos autores, pouca atenção era dedicada à complexidade estrutural e à diversidade dessas famílias. Os problemas relacionais eram tratados de forma a excluir, quase que totalmente, menções às interações positivas existentes. As diferentes configurações de famílias recasadas eram tratadas como eqüivalentes. Os autores afirmam que, na década de 1990, o número de publicações sobre recasamento e famílias recasadas foi três vezes maior do que na década anterior, e novos ângulos das questões foram investigados e debatidos. A família recasada passou a ser descrita de forma mais detalhada pela literatura, e suas especificidades passaram a ser mais conhecidas e discutidas por terapeutas e estudiosos.

Uma das entrevistadas menciona a falta de conhecimento das pessoas que recasam sobre as complicações que irão enfrentar, enfatizando também uma visão negativa:

\footnotetext{
"Eu acho que (o recasamento) é uma situação complicadíssima, sabia? As pessoas ... eu acho uma sacanagem, porque as pessoas lêem reportagens de jornais, onde todo mundo ... os seus, os meus, os nossos, é tudo tão bonito, tão harmônico ... e na verdade é tão complicado! " (TF.5).
} 
Na realidade, a entrevistada sugere que há uma espécie de "propaganda enganosa" em relação à possível harmonia da família recasada. Em outro momento, a entrevistada menciona sua crença na possibilidade de felicidade no casamento, e comenta que sua própria experiência num casamento considerado feliz e de longa duração pode representar uma influência positiva para os indivíduos que atende.

Outro entrevistado demonstra sua percepção sobre casais recasados e faz comparações com casais de primeiro casamento:

"Eu tenho a impressão que quase todos os recasamentos que eu trato tem isso... que todo mundo que é recasado tem a moral do primeiro casamento. Mesmo que esteja num segundo ou num terceiro, ele quer ter a mesma experiência, as mesmas condições de um primeiro casamento. Isso cria muito problema, porque o que eu noto, nesses recasamentos, é que na maioria deles a pessoa entra em relação deixando uma porta aberta ...caso ele queira sair. (...) eu, particularmente noto, nesses atuais recasamentos, é que as pessoas querem o que a pessoa tem de positivo, não querem pegar o pacote inteiro... 'seus problemas você mesmo cuida, não me sobrecarregue com eles, que eu tento cuidar dos meus' 'olha, o que você tiver de ruim você resolve sozinho'... mas quando ele mesmo tem um ruim, ele quer que o outro participe. (...) Quando você está num primeiro casamento, você está aprendendo junto com o outro ou com a outra, e pouco a pouco você vai assimilando as dificuldades do outro e da outra, aceitando ou não, brigando ou não, e vai construindo uma relação. Nesses segundos e terceiros casamentos, como as pessoas já são mais adultas, na maior parte das vezes elas querem ficar numa boa (...) Isso é o que eu vejo na prática, aqui, nos que vem se tratar comigo, porque quem está indo muito bem não vem aqui " ( TM.4).

A fala do entrevistado foi bastante longa. Transcrevemos apenas uma parte, para apresentarmos sua percepção a respeito dos casais recasados que atende. Além das opiniões pessoais do sujeito, percebemos que muito do que foi mencionado refere-se às relações menos estáveis, que estão sendo nomeadas de recasamento. Como já mencionamos anteriormente, existe uma tendência, mesmo por parte de terapeutas de família, à relativização do modelo de família, que acaba por considerar parcerias diversas, com diversos graus de envolvimento, como famílias. Os recasamentos descritos por TM.4, nos quais os problemas parecem ser "privatizados" e os benefícios vistos como comuns, podem denotar o que no passado era considerado um namoro sem maiores compromissos (“deixando uma porta aberta... caso ele queira sair") . Em nossa opinião, a prática da co-residência que atualmente pode acontecer mais cedo nos relacionamentos, de forma não planejada, muitas vezes é confundida com um recasamento, quando, na verdade, um ou outro parceiro não pretende exatamente isto. Podemos perceber, na resposta do entrevistado, uma comparação feita entre um primeiro casamento, no qual as pessoas vão "construindo uma relação", onde estão incluídos valores como solidariedade e persistência, e um recasamento, no qual a relação entre os parceiros é descrita como algo mais superficial e passageiro, cujo único interesse é o prazer, talvez passageiro (“elas querem ficar numa boa”). 
TF.1 também fala de comparações entre primeiro casamento e recasamento, embora o faça de uma forma diferente do entrevistado acima mencionado:

“...o recasamento sempre tem essa questão de segunda categoria, mas muito mais porque a família nuclear é a família paradigmática, ainda. O recasamento, em vez de se instituir enquanto uma outra diferença, ele se institui como uma cópia mal feita. (...) não tem nome dos vínculos, não tem nome da relação, então ele vai tentando se aproximar do que seria a família nuclear. E aí perde, porque vai ser sempre uma imitação. Ele é sempre um arremedo ... eu acho que tem isso da família ser um arremedo, e das tentativas para sair, para compensar o arremedo. Esse é um tema que eu acho que, no recasamento, desgasta muito as pessoas, e tem sempre algum membro da família, não necessariamente do casal, que está fazendo esse jogo de pesos e medidas (entre o primeiro casamento e o atual)" (TF.1).

Em uma reflexão a respeito de como ou quando o recasamento poderia aparecer como algo diferente de um "arremedo de família", a entrevistada observa:

\footnotetext{
"Eu acho que quando a cultura ... por exemplo, a gente estava falando da mudança da percepção da desquitada, para agora, para as crianças filhas do divórcio... eu acho que vai chegar um momento, também, que as famílias nucleares serão mais um tipo de família além das outras. Eu acho que a idéia única de família nuclear vai ser diminuída. Estatisticamente já está muito próximo. Agora, a gente sabe que a separação causa muita dor. A separação nunca ... os afetos ficam tão ... limpos de seqüelas, então eu acho que sempre o que vai estar marcando o recasamento como diferente da relação anterior vai ser a dor..." (TF.1).
}

A entrevistada conclui que outros momentos da vida familiar também são marcados pela dor, como a viuvez ou o nascimento de um irmão, quando o primeiro filho perde o seu lugar único e são estabelecidos jogos competitivos. Tenta demonstrar, assim, que todos esses fatos são inerentes à vida familiar, assim como a possibilidade de separações e recasamentos. Parece buscar uma imagem não patológica ou desviante para esses fenômenos familiares.

Outros entrevistados mencionam a comparação entre o primeiro casamento e os casamentos subsequentes. Ao falar sobre o tema, TM.2 também apresenta sua percepção sobre famílias:

\footnotetext{
"Acho que comparação faz parte do ser humano, a gente sempre está comparando e procurando um ideal, o que é melhor. Até têm pessoas que falam, o ideal seria a metade da $1^{\mathrm{a}}$ mulher, no caso do homem, com a metade da $2^{\mathrm{a}}$. Mas eu acho que o problema é mais forte. Como eu sou um "familiocêntrico" grave, eu digo, inclusive, que a minha religião é a família, só acredito em família, não acredito em mais nada, eu acho que a estrutura familiar é tão forte, tão forte que você já deve ter ouvido falar isso, que as
} 
pessoas dizem assim: 'família eu só tive uma, a primeira que constituí'. Na segunda até a pessoa pode ser mais feliz, as pessoas, o casal pode ser ... mas tem aquela coisa da primeira família. Fica aquela marca daquela família, principalmente se teve só filhos ali, não teve no segundo. (...) a família é uma casa ... não é tanto o gostar, é o que representa essa família, o suporte, o investimento, uma estrutura, uma sustentação, as carências todas que você coloca ali" (TM.2).

O entrevistado não deixa dúvidas a respeito de sua percepção de família e de família recasada. Entendemos que, em sua opinião, o suporte, a estrutura e o investimento familiar só são possíveis ou só existem de forma adequada em famílias de primeiro casamento. Não descarta o fato de que o casal pode até ser mais feliz em um segundo casamento, mas deixa claro que família, no sentido por ele mencionado, é a primeira que foi constituída. Mais uma vez tivemos que refletir sobre as implicações desse tipo de percepção, por parte do terapeuta, para a clínica do recasamento.

Enquanto alguns entrevistados não mencionaram a existência de filhos em sua definição de família recasada, TM.1 baseou a sua definição de recasamento neste fato. Em suas palavras:

“... é quando uma relação de pai-filho, mãe-filho precede a relação atual de casamento
daquela pessoa ... Sempre que você já entra numa relação trazendo um outra relação
anterior ... um fruto de uma relação anterior, seja uma relação que tenha durado algum
tempo, ou que tenha sido sempre uma aventura ... não importa, você traz essa relação.
Isso para mim já é recasamento. Já é diferente de um casal que se forma sem que nenhum
dos dois tenha filhos. Tem uma série de negociações, uma série de coisas que têm que ser
feitas, têm que ser ajustadas, porque senão, lá na frente, aquilo vai dar algum tipo de
problema” (TM.1).

O entrevistado citou exemplos de filhos que tinham nascido antes do casamento, frutos de relações eventuais. A despeito da eventualidade do vínculo entre os pais, considerou a situação familiar posterior a este fato como recasamento. Em sua opinião, as negociações feitas em relação ao filho, posicionavam a família em situação de recasamento.

Ao ser indagado sobre sua concepção de recasamento, o entrevistado TM.3 perguntou se estávamos nos referindo a pessoas que haviam sido casadas, e voltavam a casar depois de um período de separação. É importante ressaltar que alguns profissionais utilizam a expressão famílias reconstituídas ao invés de famílias recasadas, para referirem-se a famílias formadas a partir de relações conjugais subsequentes ao primeiro casamento. Esclarecemos sua dúvida e ele optou por definir o recasamento: 
"É a tentativa de refazer a vida ... em conjunto, em família, com a intenção de que não se faça os mesmos erros de antes" (TM.3).

Ao mesmo tempo que aponta para um desconhecimento sobre o que está sendo discutido, o entrevistado evidencia uma formulação baseada no senso comum. Indagado sobre a intenção daquele que recasa de não cometer os mesmos erros, aponta novamente para o primeiro casamento e sublinha a marca da separação, que se faz presente quando menciona a intenção de não repetir os erros no recasamento:

“Acho que existe essa intenção, porque o que mais você ouve é que as separações , em geral, são dramáticas” (TM.5).

Visher e Visher (1988) observam que as mudanças, sejam elas desejadas ou não, envolvem perdas. Comentam que mesmo quando caminhamos rumo a situações diferentes, bastante desejadas, deixamos para trás pessoas, experiências e lugares que representaram muito para nós. $\mathrm{Na}$ opinião dos autores, para os membros de famílias recasadas, as mudanças e perdas experimentadas são maiores em número e magnitude do que aquelas que ocorrem no período inicial de uma família de primeiro casamento. Afirmam que a família recasada é uma família nascida de perdas. Acrescentam que consideram importante que essas perdas sejam reconhecidas e elaboradas pelos membros da família e mencionam a importância do trabalho do terapeuta para ajudá-los nessa tarefa.

\subsection{4}

\section{$3^{a}$ categoria: Transformações sociais}

A categoria transformações sociais refere-se à percepção do entrevistado em relação às mudanças sociais que se refletem na vivência familiar, e a forma como estas repercutem na clínica. É nossa intenção verificar, também, se o entrevistado relaciona as transformações sociais com possíveis transformações em sua abordagem teórico-prática.

Visto que todos os nossos sujeitos têm entre 14 e 25 anos de prática clínica, acreditamos que, ao longo de suas experiências profissionais, eles tenham observado de perto as transformações sociais e os desdobramentos destas em suas práticas.

Houve unanimidade entre os entrevistados em relação à grande quantidade de mudanças ocorridas, assim como aos seus reflexos observados na clínica. A metade dos terapeutas descreveu as mudanças como positivas, três sujeitos 
apresentaram uma visão pouco otimista em relação às transformações, enquanto os dois entrevistados restantes apenas descreveram suas percepções, sem emitirem julgamentos sobre elas.

Dentre as transformações mais freqüentemente mencionadas pelos entrevistados, está aquela referente às conseqüências da separação conjugal. $\mathrm{Na}$ opinião de alguns sujeitos, a separação conjugal aparece na clínica de forma menos mítica, menos traumática, atualmente. Há concordância, na percepção dos terapeutas, acerca das diversas perdas sofridas pelas famílias em virtude da separação, assim como sobre a necessidade de apoio psicoterápico para alguns de seus membros. São unânimes, contudo, em considerar todo o processo de separação e suas conseqüências como um evento familiar mais facilmente assimilado por todos, fazendo parte do cotidiano social do Rio de Janeiro. Os filhos de pais separados, hoje em dia, recebem apoio e compreensão na escola e por parte dos colegas, diferentemente do que acontecia no passado.

Uma das entrevistadas mencionou seu exemplo pessoal, para ilustrar como a separação era vista no passado:

\footnotetext{
"Hoje as famílias se constituem, se separam e se reconstituem de uma forma muito mais aceita pela sociedade, pelas crianças. Eu fui de um tempo que, quando os meus pais se separaram, nos anos 60 , eu fui discriminada na rua. (...) os filhos, hoje, sofrem, mas eles podem contar com seus colegas nas escolas. Todo o sistema em volta acolhe, protege, incentiva, já não tem mais aquele preconceito. Eu posso dizer que um dos traumas da minha infância foi a separação dos meus pais. Hoje em dia você não pega mais crianças com trauma de separação dos pais. Você vê crianças reagindo à separação dos pais, mas não com trauma ... como um evento escandaloso que marca muito a vida das pessoas" (TF.6).
}

Indagada sobre como tais transformações influenciavam sua prática clínica, a entrevistada afirma que passou a ver com mais tranqüilidade e otimismo o processo de separação e de reconstrução familiar, pois percebe que as famílias apresentam maior competência para "superar esse baque e se recompor". Observa que, atualmente, vê "com menos preocupação a depressão de uma mulher ou de um homem que se separa" (TF.6).

Outra entrevistada também associa as transformações sociais à sua experiência pessoal de separação e recasamento. Fala sobre os preconceitos sofridos por "mulheres desquitadas" no passado, e observa que os comentários negativos a elas dirigidos, bastante comuns então, seriam vistos como preconceituosos e pouco aceitáveis hoje. Em sua opinião, à medida que "vai 
mudando o nome, vai mudando a expectativa, vai mudando o comportamento social em relação a certos tabus". Acrescenta que "as mudanças sociais vão se impondo e criando novas realidades, até em relação aos preconceitos” (TF.1).

Ao mesmo tempo em que fala de suas experiências pessoais e profissionais, a terapeuta nos aponta para a direção das referências teóricas pósmodernistas, que influenciam sua prática. As abordagens conversacionais e cooperativas, informadas pelo construtivismo e pelo construcionismo social, apoiam-se no princípio de que o comportamento humano é gerado numa realidade de entendimento, que é criada pela construção social e pelo diálogo. A narrativa é considerada, por essas abordagens, como um elemento fundamental na construção das idéias e das ações humanas (Anderson e Goolishian, 1998). A resposta da entrevistada nos revela que, a partir das transformações sociais relacionadas à separação conjugal, as narrativas e as denominações referentes ao tema, também se transformaram, o que implica na necessidade de reavaliação das abordagens de terapia de família. É possível observar que a Terapia de Família acompanha o relativismo presente nas transformações sociais pós-modernístas, fenômeno que é indicado em algumas de suas formulações teóricas.

A busca por psicoterapia por um número cada vez maior de famílias recasadas, além do surgimento de famílias uni-parentais e de casais homossexuais na clínica, foram algumas das transformações mencionadas pelos entrevistados. Uma das entrevistadas observou que, no passado, casais homossexuais raramente procuravam ajuda psicoterápica, e quando o faziam, preocupavam-se em chegar à clínica em horários que permitissem maior privacidade em relação aos outros pacientes. Em sua opinião, hoje, tudo isto é visto "com maior naturalidade".

TF.4 comenta que em 1988, quando começou seu trabalho clínico, a busca por psicoterapia era mais pautada pela doença. Atualmente, embora exista um número grande de pessoas que procuram terapia numa situação de crise, há uma busca "para ficar melhor, como uma ação preventiva". Ao falar em prevenção, fenômeno que a entrevistada aponta como recente no Rio de Janeiro, menciona também a presença de famílias uni-parentais funcionais, atualmente, na clínica. Este fato denota, em sua opinião, o desejo dessas famílias de atuarem preventivamente.

Um dos entrevistados considerou como uma transformação positiva o maior empenho e consciência das pessoas em busca da felicidade. Observou que 
este empenho fica evidente na liberdade de escolha de novas relações conjugais mais satisfatórias.

Dentre os entrevistados que apresentaram uma percepção menos positiva em relação às transformações ocorridas ao longo do tempo, está a opinião de TF.5. A entrevistada menciona um tema que não foi abordado pelos outros. Fala do que chamou de "exclusão do pai” de um grande número de famílias. Afirma que percebe este fato como uma "opção" das pessoas de "expulsar, de fazer uma família onde o pai não é uma figura necessária”. Observa que a mulher e a criança são acolhidas pela família de origem, que por razões diversas excluem o pai. A entrevistada mencionou, também, o aumento do número de famílias recasadas em sua prática, e comentou sua dificuldade em tentar não passar seus próprios valores sobre casamento e família para este grupo familiar. Comentou que os valores pessoais do terapeuta acabam por "invadir" seu julgamento sobre as pessoas que atende.

TM.1 também refere-se à falta de pai nas família, mas de forma diferente da entrevistada acima mencionada. Observa que há um número expressivo de mulheres vivendo com seus filhos, sem um companheiro ou mesmo sem qualquer referência de pai para a criança. Em sua opinião:

\footnotetext{
"É como se as pessoas tivessem perdido um pouco referências importantes, valores importantes, até a própria questão de gênero . Quer dizer, como eles definem quem faz o que, ou quem deveria estar fazendo o que" (TM.1).
}

Indagado sobre sua forma de lidar com essas transformações na clínica, afirmou que, à medida que os terapeutas vão mudando seu próprio conceito de família, esta mudança vai se refletindo na prática clínica. Mencionou a necessidade de uma auto-vigilância constante, para "não passar para os clientes seus próprios valores e ideais, numa simples pergunta, aparentemente inocente" (TM.1).

Ao longo de seus comentários sobre o tema, o entrevistado mostra uma contradição entre a tentativa de mudança do conceito de família e seus próprios valores, que apontam para um modelo familiar, no qual a definição de papéis familiares e sua relação com os gêneros é clara.

A contradição entre a relativização de um modelo de família que atenda à realidade atual daqueles que buscam a clínica, e o conceito de família do terapeuta 
entrevistado, apareceu diversas vezes ao longo das entrevistas. Tal contradição nos fez refletir sobre a compatibilização entre as referências teóricas utilizadas pelos terapeutas entrevistados e a prática. Um dos entrevistados explicitou esta contradição do seguinte modo:

\footnotetext{
"A gente estudava, antes, uma teoria para tratar uma família que não existia mais, e de repente fomos obrigados a ver o que a gente estava tratando. Porque o problema era do valor do terapeuta e o valor da família. A família vinha aqui porque queria uma coisa, não o que o terapeuta queria ... e isso foi uma coisa que a gente está aprendendo e continuará aprendendo, porque vai mudando sempre ...muitas vezes o que é uma coisa muito chata para você, não é para a família " (TM.4).
}

O entrevistado comentou que as transformações não afetavam a abordagem clínica por ele utilizada. Esclareceu que como terapeuta sistêmico, trabalhava com o contexto, podendo modificar suas intervenções clínicas de acordo com as modificações do próprio contexto. A resposta do entrevistado nos indica que a teoria lhe oferece uma visão a respeito da prática que parece ser uma fórmula abstrata e universal. Fórmula esta que não se transforma, apesar da transformação dos contextos.

Embora o entrevistado afirme que a teoria sistêmica permite que se trabalhe dentro de qualquer contexto, a revisão da literatura sobre o tema trata de uma série de variáveis que se interpõem entre o contexto e o terapeuta. Em primeiro lugar, como já mencionamos antes, o modelo de família que o terapeuta tem como referência, influencia e direciona suas intervenções clínicas. Um outro fator que se reflete no modo como o(a) terapeuta interpreta as questões a ele(a) levadas, e que foi amplamente mencionado pelos entrevistados, é a sua própria experiência conjugal e familiar. A despeito de seu comentário sobre a possibilidade de trabalhar igualmente em diferentes contextos, o entrevistado admitiu ter mais dificuldade em tratar pessoas que querem se divorciar ou casais recasados, por não ter tido esse tipo de experiência. Acrescentou que se fosse divorciado e recasado, "trataria isso com menos engajamento emocional, com mais objetividade".

Outros entrevistados mencionaram situações familiares pessoais, observando que a partir de sua próprias experiências desenvolveram maior empatia por determinados temas e puderam compreender mais claramente as situações descritas pelos clientes. 
John e Emily Visher, mencionados diversas vezes ao longo do presente estudo por suas contribuições ao trabalho com famílias recasadas, desenvolveram o interesse pelo tema a partir do próprio recasamento. Em um artigo onde exorta a importância de um conhecimento maior das especificidades das famílias recasadas por parte dos terapeutas, John Visher (1994) fala de sua própria experiência com o recasamento. Admite que o casal teve inúmeras expectativas irrealistas em relação ao funcionamento da nova família, embora ambos fossem terapeutas. Perceberam, também, que sabiam pouco, assim como outros terapeutas da mesma época, sobre as características específicas das relações familiares no recasamento. Partiram da experiência pessoal para o desenvolvimento de pesquisas e para a criação de uma associação voltada para o estudo e o tratamento das famílias recasadas.

Da mesma forma que as experiências pessoais do terapeuta podem auxiliálo em relação à compreensão das situações trazidas por seus clientes, em determinadas situações, a literatura menciona a necessidade de um entendimento mais detalhado em relação às suas possíveis interferências dessas experiências no trabalho clínico. Simon (1995) observa que, assim como os institutos psicanalíticos sempre consideraram a necessidade das análises pessoais dos psicanalistas como um pré-requisito para seu trabalho, a formação do terapeuta de família requer o entendimento detalhado da própria família. O autor cita o trabalho de Murray Bowen, a respeito do tema, para quem tal entendimento é considerado um complexo empreendimento de pesquisa. O objetivo dessa pesquisa é a compreensão da rede de regras e expectativas familiares presentes na socialização do terapeuta.

Observamos que, ao falarem acerca das transformações sociais, alguns dos terapeutas entrevistados também avaliaram de que forma as transformações tinham influenciado suas próprias vidas, antes de refletirem-se em suas clínicas. Uma entrevistada descreveu este fato da seguinte forma:

“ Depois que me divorciei, a minha possibilidade de trabalhar com o divórcio é muito diferente do que quando eu era casada. (...) Eu acho que as situações da vivência nos dão uma possibilidade diferente do que as situações da clínica" (TF.4).

$\mathrm{Na}$ opinião de TM.2, entretanto, as transformações sociais apenas “colorem as famílias", pois os processos presentes nas relações familiares, 
descritos pelos autores, como lealdades, triangulações, alianças, coalisões ocorrem tanto hoje quanto ocorriam na família de 50 anos atrás. Afirma que as transformações apenas deram abertura para questões já existentes no passado. Comenta que o homossexualismo já existia, o que não existia era "a família dita homossexual". Observa que, o que as transformações sociais imprimiram foi a “multiplicidade, a variedade de famílias". Apresenta uma visão negativa das mudanças quando afirma que tanto os pais quanto os filhos perderam os rumos das regras e da liderança familiar. Enfatiza a existência de uma atitude de contestação social em relação às regras familiares predominantes no passado, atribuída ao que chamou de "psicologismo". Segundo o entrevistado, tal contestação acabou por tomar proporções exageradas e houve uma perda de referenciais anteriores, causando a atual falta de rumo na educação de crianças e adolescentes. Como já observamos antes, este terapeuta apresenta uma forte influência de Salvador Minuchin, com sua ênfase na definição de fronteiras bem delimitadas, caracterizando uma família saudável.

Ao mencionar referenciais anteriores, utilizados como parâmetros para regras e rumos familiares, além de lamentar sua perda, o entrevistado aponta para sua própria referência de um modelo ideal de família, já mencionado ao longo do presente estudo. A constante referência a este ideal nos remete, mais uma vez, à questão da possibilidade de um tratamento psicoterápico bem sucedido com famílias recasadas. Concordamos com a posição de McGoldrick e Carter (1999), descrita no Capítulo 2, que propõem a necessidade de um paradigma de família novo para a família recasada, que contemple a complexidade dos novos relacionamentos e funções familiares. É inevitável que haja uma acomodação diferente em relação às regras familiares e às lideranças deste grupo, e que estas sejam devidamente reconhecidas pelos terapeutas.

As transformações sociais e a forma como elas foram apresentadas pelos entrevistados nos remetem a características pós-modernas, como a relativização do saber do especialista, a diversidade de configurações familiares e a multiplicação dos saberes e das experiências, tanto por parte do terapeuta quanto das famílias. 


\subsection{5}

\section{$4^{\mathrm{a}}$ categoria: Queixas relacionadas ao recasamento}

Esta categoria refere-se às queixas mais comuns, na opinião do(a) terapeuta entrevistado(a), desencadeadas pela situação de recasamento. Pretendemos também verificar se há coincidências e/ou diferenças entre as queixas mais comuns registradas na literatura estrangeira e as queixas mencionadas por terapeutas de família do Rio de Janeiro.

Como foi discutido ao longo do trabalho, o recasamento propicia uma série de características, na estrutura e no relacionamento familiar, que são específicas dessas configurações familiares. A revisão da literatura nos informa sobre os efeitos negativos gerados pela falta de informação, por grande parte das famílias, em relação a essas especificidades. A literatura especializada enfatiza, também, o papel do terapeuta quanto à transmissão de informações sobre o tema, aos membros das famílias recasadas. Os autores são unânimes em afirmar que o conhecimento acerca das diferenças entre famílias recasadas e famílias de primeiro casamento, às quais as famílias recasadas são constantemente comparadas, representa uma etapa importante do processo terapêutico deste grupo familiar (Sager e colaboradores, 1983; Visher e Visher, 1988, 1996, 1997; Visher, J., 1994; Bray e Kelly, 1998; McGoldrick e Carter, 1989, 1999).

Ao longo do trabalho, nos deparamos com especificidades e queixas, em relação ao recasamento, descritas por terapeutas estrangeiros. Um dos nossos objetivos, no desenvolvimento desta categoria de análise, foi verificar se tais informações coincidiam com aquelas mencionadas pelos nossos sujeitos.

Em relação à esta categoria, primeiramente quisemos ouvir a opinião dos entrevistados sobre o conhecimento das famílias atendidas em relação à dinâmica familiar no recasamento. Perguntamos, então, aos sujeitos se era comum a existência de queixas não rotuladas como tais, referirem-se às especificidades do recasamento. Houve concordância da maioria dos entrevistados acerca do desconhecimento e das expectativas irrealistas, por parte dos membros de famílias recasadas, no que se refere às relações criadas pelo recasamento.

A literatura estrangeira nos mostra a preocupação dos profissionais de diferentes áreas em envolver a sociedade no debate e nas pesquisas sobre famílias recasadas, devido ao aumento significativo de recasamentos (Visher e Visher, 
1988; Levin, I., 1997; Fine, M., 1997; Hughes Jr., R., e Schroeder, J., 1997). As publicações acima mencionadas evidenciam que uma mudança de postura da sociedade em relação à formação de novas famílias pelo recasamento é um elemento fundamental para integração familiar e social de seus membros. É interessante compararmos esta informação com a resposta de um de nossos sujeitos acerca do conhecimento das especificidades do recasamento pelas famílias recasadas :

\footnotetext{
"Não, não fazem esse tipo de ligação entre o que está acontecendo com eles naquele momento... Eu acho que isto é a nossa ótica, eu acho que já estamos colocando aí uma lente, vendo ... significando aquela situação como sendo própria de uma situação de recasamento. Inclusive me reservo esse direito de falar, mesmo, o que se observa hoje, o que se tem teoricamente sobre isso ... Eu até me pergunto, novamente, será que estou pondo um valor meu nessa história? Mas acredito que essa informação é útil para eles... que você não pode tratar como se fosse completamente diferente, como algo inusitado, nem igual, porque não é também. Você tem que fazer a diferenciação de um, de outros casais, mas também não achar que é uma coisa do outro mundo. É diferente ...” (TM.1).
}

Os debates e pesquisas atuais sobre o tema mostram a importância da informação para esse grupo familiar, o que é timidamente mencionado pelo entrevistado. A chamada psicoeducação, recurso utilizado na clínica, refere-se às informações transmitidas às famílias, no contexto terapêutico ou fora dele, seja através de material escrito, palestras, filmes ou de informações elaboradas pelo(a) próprio(a) terapeuta (Visher \& Visher e colaboradores, 1997).

As palavras do entrevistado TM.1 apontam, também, para a tendência pósmodernista de relativização do saber do especialista. Tal relativização é discutida por Anderson e Goolishian (1995), num texto onde descrevem a posição de nãosaber do terapeuta. Afirmam que esta posição requer que o entendimento, as explicações e interpretações feitas pelo(a) terapeuta não sejam limitadas por experiências anteriores ou por conhecimentos ou verdades teoricamente formados. O papel do terapeuta, para este tipo de abordagem, é de facilitar um processo dialógico para que novos sentidos, novas realidades e novas narrativas possam ser co-construídas. O entrevistado TM.1, por mais de uma vez ao longo da entrevista, mostrou-se preocupado em não interferir na opinião e nos valores de seus clientes. É possível observar o seu empenho em colocar-se na posição de não-saber. Acreditamos que esta seja uma discussão a ser realizada. Será que adotar a posição de não-saber significa impedir que nossos valores interfiram na prática clínica? Levantamos esta discussão a respeito do recasamento ao afirmarmos a 
influência do modelo de família nuclear na prática terapêutica. Assim, acreditados que não se trata de impedir interferências, mas de elaborá-las.

A posição acima mencionada pode ser contrastada com a postura de terapeutas de família mais tradicionais, como evidencia a descrição que Minuchin faz de sua própria abordagem terapêutica. Em suas palavras:

\footnotetext{
"Minha terapia é o encontro ativo entre uma família que precisa de ajuda e um terapeuta especialista, contratado por tempo limitado para dirigir e melhorar a capacidade curativa dos membros da família" (Minuchin, 1999, p.12) *
}

Podemos perceber que o autor coloca-se como um especialista, contratado pela família, para dirigi-la em seu trajeto rumo a um processo curativo. Esta postura fica evidente também em um texto sobre técnica, no qual Minuchin observa:

\begin{abstract}
"Há uma variedade de técnicas para transmitir a mensagem de que a família e seus membros dispõem de mais alternativas possíveis além de suas modalidades prediletas de interação. $\mathrm{O}$ objetivo é sempre a conversão destas à uma concepção diferente do mundo uma concepção que não necessita do sintoma - e para uma visão pluralista da realidade mais flexível - uma visão que permita diversidade dentro de um universo simbólico mais complexo. As técnicas para mudar a realidade da família agrupam-se em três categorias principais. Estas são: a utilização de símbolos universais, verdades familiares e conselho profissional" (Minuchin, 1990b, p.207).
\end{abstract}

As palavras do autor contrastam com a posição de não-saber, mencionada acima. Aqui o terapeuta é um especialista. Possui não apenas conhecimento específico sobre o funcionamento familiar, como recursos técnicos capazes de converter as modalidades prediletas de interação familiar consideradas disfuncionais.

Como já foi mencionado anteriormente, as respostas dos entrevistados demonstram que o grupo de sujeitos pode ser dividido entre terapeutas que demonstram familiaridade e preferência por abordagens tradicionais, em consonância com as palavras de Minuchin, e aqueles que buscam uma direção calcada no discurso pós-modernista. Como exemplo desta divisão, podemos citar o entrevistado TM. 2 que, embora concordando com a resposta de TM.1 quanto ao fato dos membros de famílias recasadas não relacionarem suas queixas às

\footnotetext{
* Tradução da autora
} 
situações do recasamento, o faz através de uma abordagem diferente. Observou que as queixas dos membros de famílias recasadas apontavam para direções diversas como, por exemplo, "os sintomas do filho de um dos lados". A ligação entre o sintoma e o recasamento só surgiria posteriormente. Podemos perceber que o entrevistado faz um paralelo com noções utilizadas pela terapia de família tradicional, direcionada para a família nuclear na qual, muitas vezes, conflitos conjugais podem ser denunciados pelo sintoma de um filho. Embora pesquisas sobre recasamento também descrevam dificuldades e conflitos psicológicos apresentados por filhos e enteados dessas famílias, tais eventos são interpretados, na maioria das vezes, como parte das dificuldades e dos conflitos específicos da situação de recasamento.

O entrevistado TM.4, ao contrário da maioria dos outros sujeitos, afirma que as famílias recasadas que o procuram na clínica relacionam suas queixas à situação de recasamento. Menciona as expectativas irrealistas dos membros da família, antes de partilharem suas rotinas, mas observa que a busca por psicoterapia já vem acompanhada de dados objetivos sobre a nova realidade familiar. Sua resposta evidencia que há uma falta de conhecimento, por parte dos membros do casal, acerca da complexidade das relações que serão criadas a partir da nova união. Aponta também para a expectativa dos envolvidos em reconstruir relações semelhantes àquelas da família nuclear, criadas num primeiro casamento.

Embora cada entrevistado tenha apresentado um viés particular na definição das queixas mais comuns dos membros de famílias recasadas, houve unanimidade ao mencionarem três temas recorrentes: filhos de casamentos anteriores de um ou de ambos os membros do casal, ex-cônjuges, e finanças. Essas queixas também são amplamente discutidas na literatura estrangeira, embora sejam identificadas como temas das discussões iniciais sobre recasamento, presentes em publicações da década de 1970 e início da década de 1980 (Visher \& Visher e colaboradores, 1997). A literatura mais recente sobre o tema demonstra uma preocupação maior em relação à prevenção e ao tratamento específico dos conflitos do que na descrição dos mesmos, visto que já foram discutidos à exaustão em décadas anteriores. Nossos entrevistados, entretanto, estavam apenas listando as queixas mais comuns escutadas por eles na clínica, de acordo com a pergunta feita. 
Em relação aos filhos e enteados, foram mencionados conflitos de lealdades, sentimentos de culpa e remorso, falta de autoridade, expectativas irrealistas envolvendo a relação padrasto/madrasta e enteados, obrigatoriedade de amar os novos membros da família e comparações diversas.

O tema "ex-cônjuges" também apareceu como uma queixa bastante abrangente. A entrevistada TF.1, contudo, fez algumas observações mais específicas, relacionadas à separação conjugal. Analisemos fragmentos de sua resposta:

\footnotetext{
"Outro tema que eu acho que foi muito pouco atendido pelos especialistas e que acho muito importante, é o tema de quem escuta e quem diz o não ... Um casal de recasamento em que os dois são divorciados, se os dois forem autores dos seus divórcios anteriores, se um é viúvo, o outro não é ... todos esses são temas que, para mim, desenvolvem muitas reflexões a partir de como eu escuto, como é que foi escutado o não, como é que foi dito ..." (TF.1).
}

A entrevistada aponta para a assimetria de sentimentos e experiências geralmente existentes tanto na separação conjugal quanto no recasamento. Enfatiza, concluindo o que foi citado acima, que o terapeuta deve estar atento a esta assimetria, pois é a partir dela que surgem diferentes sentimentos e diferentes narrativas por parte dos ex-cônjuges.

Telefonemas inoportunos e reivindicações diversas foram repetidamente mencionadas pelos entrevistados como interferências dos ex-cônjuges no recasamento. Alguns sujeitos mencionaram os temas finanças, ex-cônjuges e filhos como uma queixa única. Neste caso referiram-se, especificamente, às exmulheres e às suas reivindicações para que os ex-maridos destinassem mais recursos financeiros para os filhos do primeiro casamento.

As perdas financeiras advindas da separação foram mencionadas muitas vezes como causadoras de conflitos e uma queixa comum. As palavras da entrevistada TF.4 resumem, os comentários dos entrevistados sobre o tema:

É muito difícil quando, depois da separação, uma família, considerando os filhos comuns, tem discrepância acentuada de possibilidade financeira da outra. Isso é uma situação muito difícil para os filhos lidarem, mas, especialmente, para aquele mais pobre. Aí entram as ameaças de outras naturezas, porque aquilo que está sendo dado para a família nova, às vezes na fantasia, às vezes na realidade, está sendo deixado de dar aqui... É um tema de discordância, com certeza" (TF.4). 
Embora o entrevistado TM.4 tenha mencionado queixas semelhantes às citadas pelos outros entrevistados, sua escolha de palavras para descrevê-las possibilita uma reflexão sobre sua própria concepção sobre o tema. É o seguinte seu comentário sobre as queixas dos membros de famílias recasadas:

\footnotetext{
"Uma das principais (queixas), que eu até hoje não encontrei solução, é o problema financeiro. Porque se você tem filhos com outro casamento, e você começa uma relação de segunda, agora, e vocês trabalham para essa relação, em princípio o trabalho deve ser para os membros dessa família nova. Acontece que você tem uns filhos dependurados, que você precisa sustentar também. $O$ seu cônjuge vai trabalhar para esses filhos que não são dela ou dele também? É um problema muito complexo. Quase sempre ela ou ele acham que os ex não estão sendo bastante responsáveis para manter os filhos deles “ (TM.4).
}

As respostas dos entrevistados acabam por deixar transparecer suas próprias concepções sobre recasamento, como foi apresentado nas categorias iniciais. Ao falar sobre a influência da situação familiar do terapeuta em sua prática, TM.4 admitiu que sua experiência pessoal de um único casamento, estável, faz com que ele sinta menos familiaridade com as dificuldades relacionadas à separação conjugal e ao recasamento. Em nosso entender, não são apenas as experiências pessoais que dificultam ou facilitam o entendimento de questões trazidas para a clínica, mas a própria percepção do terapeuta em relação aos diferentes temas. $\mathrm{O}(\mathrm{A})$ terapeuta certamente não terá vivenciado todos os conflitos e situações encontradas na clínica, mas suas próprias concepções, conhecimento e elaboração dos diferentes temas, coerentemente aliados ao conhecimento específico provindo de uma fundamentação teórica, podem lhe propiciar os instrumentos necessários para tratar conflitos diversos.

A falta de autoridade do padrasto em relação aos enteados foi mencionada como queixa comum por duas entrevistadas. As palavras de TF.5, por exemplo, evidenciam sua percepção do modelo de família nuclear, no qual o homem deve exercer o papel de autoridade:

\footnotetext{
"Eu acho que essa coisa, principalmente do homem, que entra no sistema, não se sentir autorizado, da mãe não deixar esse novo parceiro entrar, ter um papel de autoridade: 'com os meus filhos você não mexe', 'até aqui mando eu...', quer dizer, o dever do pai. Eu sinto muito isso, do marido se sentir totalmente descartado, de querer desempenhar o papel de pai e ser alijado do sistema" (TF.5).
} 
As palavras da entrevistada nos fizeram refletir, mais uma vez, sobre o papel do terapeuta que se propõe a tratar famílias recasadas. Se os membros da família trazem para a terapia as noções de funcionamento familiar baseadas em famílias de primeiro casamento, cabe ao terapeuta apresentá-los às questões específicas dessa nova configuração familiar na qual estão inseridos. $\mathrm{O}$ tratamento torna-se inviável, porém, se o terapeuta também busca enquadrar a família recasada no modelo de família nuclear.

A entrevistada TF.6 também faz a relação entre os homens e a necessidade de exercer a autoridade com os enteados:

"Os homens não sabem como colocar essa autoridade, a questão da hierarquia. Ele não sabe se tem 100\% autoridade com o filho do outro, ou se é uma coisa de meio a meio. Qualquer coisa que ele chama a atenção, ele não sabe se está sendo bem recebido ou se está sendo comparado... Então, as vezes, o homem tem muita dificuldade de lidar com a qualidade e o nível dessa hierarquia e dessa autoridade em casa” (TF.6).

A literatura aborda a questão da autoridade parental em famílias recasadas, e as pesquisas clínicas apontam para direções que podem ser escolhidas pelos adultos envolvidos, com o intuito de contornarem essas questões. McGoldrick e Carter (1999) sugerem que, no exercício da autoridade, sejam priorizados os vínculos biológicos ou históricos (em caso de adoção) com os filhos. Tal sugestão evidencia que estas relações ainda são regidas pelos vínculos biológicos, ou seja, os núcleos são diferenciados pelo vínculo biológico, que determina a autoridade. A família recasada que busca terapia, certamente deverá ter ampla oportunidade de discutir questões de relacionamento familiar, chegando a conclusões que melhor se adeqüem às suas características pessoais. Padrasto ou madrasta pode ser considerado como um adulto próximo, responsável e que se propõe a dividir com seu parceiro(a) os cuidados com filhos e enteados. McGoldrick e Carter observam também que a divisão de tarefas familiares por gênero deve ser reavaliada e redistribuída de acordo com a estrutura de cada família, e sugerem que a tentativa de substituição do pai/mãe biológico(a) pelo padrasto/madrasta deve ser evitada. 


\subsection{6}

\section{$5^{a}$ categoria: Relação teoria-prática}

Esta categoria refere-se às relações, feitas pelo sujeito ao longo da entrevista, entre sua prática clínica e o referencial teórico que a fundamenta. Refere-se, ainda, ao interesse e conhecimento do entrevistado acerca de pesquisas relacionadas ao recasamento.

A psicanálise foi mencionada como a primeira orientação teórica utilizada por nove dos sujeitos entrevistados, antes de buscarem uma formação na área de família. Suas respostas convergiram ao comentarem que sentiram a necessidade de um suporte teórico/prático para os atendimentos que envolviam famílias. Todos os terapeutas entrevistados afirmaram ter iniciado suas formações em terapia de família através do referencial sistêmico. Ao longo de suas carreiras, entretanto, alguns deles foram fazendo novas leituras, o que os afastou do referencial teórico inicial. Enquanto em algumas entrevistas a relação teoria-prática aparece implicitamente, em outras esta relação é mencionada de forma explícita. A entrevistada TF.1, por exemplo, mencionou as transformações relacionadas a referenciais teóricos, ocorridas ao longo de sua trajetória profissional. Observou que para profissionais como ela própria, vindos da psicanálise, a terapia sistêmica, a princípio, pareceu uma abordagem bastante interventiva. Comentou, porém, que via positivamente a preocupação da terapia sistêmica com indicadores de melhora, mas que não havia abandonado "o lado dos questionamentos humanos que não são tão mensuráveis quanto a matematização do ser humano, que foi o modelo cibernético, o modelo do sistema”. Definiu sua relação teórico-prática da seguinte forma:

\footnotetext{
"Eu, hoje em dia, não me diria sistêmica. Eu diria que sou uma terapeuta muito mais voltada para a escultura que esses vínculos e essas linguagens compartilhadas vão fazendo no discurso. Eu acho que adotei o construcionismo social muito mais como um desenho da minha transformação dentro do campo. Quer dizer, eu não sou interventiva, sou uma pessoa que converso, com um setting muito sóbrio, até, mas a minha preocupação é sempre como é que as pessoas vão esculpindo a sua realidade" (TF.1).
}

As palavras da entrevistada, ao longo de toda a entrevista, evidenciam uma preocupação constante em refletir sobre teoria, prática e sobre as transformações 
em geral. Além da avaliação das transformações ocorridas no campo da terapia de família, a entrevistada parece avaliar e comparar suas transformações pessoais, no intuito de ampliar sua própria capacidade de compreensão relacionada às experiências clínicas. Indagada sobre sua disponibilidade atual de trabalhar em pesquisas relacionadas ao recasamento a entrevistada comentou:

\begin{abstract}
"Não, porque aí eu acho que mergulharia numa coisa que já estou mais afastada, que é ficar muito ocupada com a estrutura. Eu não sou mais estruturalista. Estou muito mais voltada para a construção do sentido. É claro que as pessoas que estudam essa estrutura cooperam comigo, mas como é que se constrói esse sentido? Se eu ficar muito estruturalista, posso correr o risco de engessar idéias que estão em movimento. Quero saber como é o processo de desengessamento de idéias, para que o recasamento ocupe o lugar de mais uma família que existe nas possibilidades dos encontros familiares" (TF.1).
\end{abstract}

É interessante observar que, a partir de suas próprias transformações dentro do campo da terapia de família, a entrevistada TF.1 adota uma abordagem calcada no construcionismo social. Embora diga que não é mais estruturalista, a entrevistada menciona diversas vezes a noção de fronteiras, que é um conceito essencial para a Terapia de Família Estrutural. Relembrando o que já foi mencionado no Capítulo 3 , é a seguinte a definição de fronteira de Minuchin (1990a):

\begin{abstract}
"As fronteiras de um subsistema são as regras que definem quem participa e como... A função das fronteiras é de proteger a diferenciação do sistema. Cada subsistema familiar tem funções específicas e faz exigências específicas a seus membros... Para o funcionamento apropriado da família, as fronteiras dos subsistemas devem ser nítidas" (p.58).
\end{abstract}

A entrevistada TF.1 utiliza o conceito de fronteiras ao falar de queixas comuns das famílias recasadas e ao descrever diferenças entre o atendimento psicoterápico a famílias de primeiro casamento e a famílias recasadas:

\footnotetext{
"Um tema de queixa comum na família de recasamento são as fronteiras. O desenho de fronteira do que é o casal, das alianças, das cumplicidades, da fidelidade, de quem é mais importante, quem é menos importante, é o tema da família de recasamento, na sua busca de equilibrar o seu desenho de alguma forma" (TF.1).

"A forma como eu atendo as famílias recasadas não é diferente. Possivelmente a minha leitura do que está acontecendo ali obedece a uma leitura de que eu sei que tem uma estrutura diferente, um desenho diferente, questões e desafios diferentes do casal de primeiro casamento. Quer dizer, o casal de primeiro casamento está construindo fronteiras com as famílias de origem, com os amigos que cada um traz. Uma família de recasamento vai estar falando de fronteiras de outros lugares. A minha escuta vai ser a partir da
} 
construção que eles fizeram, do que eles estão definindo que é a situação problema" (TF.1).

Não percebemos o uso da noção de fronteiras como uma contradição teórica, pelo fato de a entrevistada não se considerar estruturalista, mas como uma soma de conhecimentos que podem beneficiar as famílias ou indivíduos atendidos, própria do relativismo pós-moderno. As palavras de TF.1 nos remetem ao artigo que Carlos Sluzki (1998) desencadeado pelas críticas feitas por Minuchin (1998) à terapia narrativa (vide Capítulo 3). Ao defender a possibilidade de utilização de intervenções sistêmicas em sessões de terapia onde a família não está presente, Sluzki comenta que não é apenas na família que a ordem social e os sentidos são negociados. Tais negociações podem se dar na interação com amigos, inimigos, colegas de trabalho, professores, alunos, entre outros, além do nosso próprio mundo subjetivo. As intervenções sistêmicas, portanto, podem se dar, legitimamente, em outros terrenos, sem que a família seja descartada pela mudança de foco na prática. O cuidado que se deve ter, segundo o autor, é para que essas intervenções não sejam nomeadas de terapia de família, evitando, assim, críticas como as de Minuchin. As idéias de TF.1 parecem estar em sintonia com a posição defendida por Sluzki. Ao descrever o público que atende, a entrevistada mencionou que sua clínica era voltada para adultos, com questões em relação à vida amorosa, às decepções amorosas e ao exercício da vida familiar. Perguntamos, então, se ela ainda se denominava terapeuta de família, ao que respondeu:

\footnotetext{
"Eu acho que cada vez mais, com a idade, com o amadurecimento, eu acho que eu me
} chamo de terapeuta" (TF.1).

Ao analisarmos a entrevista de TF.1 como um todo, podemos perceber que a entrevistada adota uma postura receptiva em relação às transformações sociais e àquelas do campo da terapia de família. Seu discurso sobre a prática clínica indica sua constante reflexão sobre os temas com os quais trabalha e a busca por novos conhecimentos.

Cinco dos sujeitos entrevistados deram exemplos de suas práticas, relacionando-as à teoria sistêmica. O entrevistado TM.4, por exemplo, faz essa relação ao explicar de que forma lida com as transformações sociais em sua 
prática clínica, ressaltando o modo como a teoria sistêmica vê a influência do contexto sobre o indivíduo:

"Quando você é sistêmico, você trabalha em contexto. Se o contexto muda, você muda também. Esse é um dos princípios básicos da terapia de família. A família é o contexto onde o indivíduo está inserido, se você trabalha naquele contexto você ajuda o indivíduo" (TM.4).

Os outros sujeitos foram menos explícitos em relacionar teoria e prática, mas suas palavras evidenciaram a existência de uma leitura pós-modernista. Mencionaram construções de novas narrativas, novas possibilidades criadas através da co-construção de novas histórias e colocaram-se na posição de colaboradores das famílias e de seus membros, ao invés de ocuparem a posição de especialistas. Demonstraram preocupação em não deixar que seus próprios valores pudessem informá-los sobre o que seria mais adequado para seus clientes, mas em escutá-los a partir de uma postura de não saber, conforme descrita por Anderson e Goolishian (1995) e mencionada anteriormente.

Pudemos perceber que esta nova leitura dos sujeitos aparece bastante entremeada de elementos, por vezes contraditórios, da formação inicial sistêmica de alguns desses entrevistados. Acreditamos, contudo, que esta contradição seja um aspecto comum nas transformações em geral, e que tais transformações necessitam de um volume maior de tempo, pesquisas e debates para se estabelecerem de forma mais abrangente e estável.

No intuito de avaliarmos o interesse dos entrevistados pelo recasamento e pelos seus desdobramentos na clínica, perguntamos quais eram seus autores favoritos e se eles conheciam pesquisas sobre o tema no Brasil. É importante salientar que um dos sujeitos entrevistados é bastante conhecido no campo da terapia de família por seu interesse pelos temas recasamento e separação conjugal, já tendo publicado artigos e livros. Embora seus livros não sejam voltados para profissionais da área, mas para o público em geral, eles foram mencionados pela maioria dos outros entrevistados como referências.

Em relação a pesquisas sobre o tema, todos os entrevistados afirmaram não ter conhecimento de estudos, no Brasil, referentes a essa área. Um dos entrevistados, ao dizer que não conhecia pesquisas sobre recasamento no Brasil, comentou: "Não. Eu tenho a impressão que quem talvez faça isso é gente de 
universidade". Em nosso entender, as instituições formadoras de terapeutas de família e os cursos de psicologia das universidades deveriam desenvolver relações de troca de conhecimento mais estreitas. Os cursos denominados de formação, bastante procurados por alunos dos cursos de psicologia como forma de especialização em terapia de família e outras modalidades terapêuticas, também dividem suas aulas entre teóricas e práticas. Aparentemente, as pesquisas realizadas em universidades brasileiras e estrangeiras não ocupam um lugar de relevância em seus conteúdos programáticos.

Algumas respostas relacionadas às perguntas acima mencionadas nos trouxeram novas informações a respeito das percepções dos entrevistados. Observamos que mais da metade dos entrevistados (seis sujeitos) não pareceu considerar tão relevante, para o seu trabalho clínico, o conhecimento das especificidades das famílias recasadas. Nas questões que envolviam essas especificidades, as respostas apoiavam-se na experiência clínica com famílias de primeiro casamento, ou pareciam basear-se em premissas do senso comum. Refletimos sobre as respostas e concluímos que elas poderiam ser analisadas através de dois aspectos distintos. Por um lado, a resposta muitas vezes repetidas de que a família recasada "era uma família como outra qualquer" (assim como foi mencionado em relação às famílias homossexuais, uniparentais e adotivas, por exemplo), aponta para uma posição que nomeamos de politicamente correta, por parte de terapeutas de família contemporâneos. Significa que as diferentes configurações familiares devem ser tratadas igualmente, sem que os possíveis preconceitos e/ou valores pessoais dos terapeutas interfiram no processo terapêutico.

Por outro lado, as pesquisas publicadas fora do Brasil sobre o tema indicam que quanto maior o conhecimento específico sobre o funcionamento das famílias recasadas e sobre os relacionamentos desenvolvidos entre seus membros, maiores são as possibilidades de ajuda psicoterápica. O mesmo raciocínio pode ser estendido a outras configurações familiares que se caracterizam por traços distintos daqueles das famílias nucleares. Entendemos que existe uma diferença entre a aceitação das diversas configurações familiares e o conhecimento mais amplo acerca de seu funcionamento. Ao negarmos a existência das especificidades dos diferentes grupos, estamos, de uma certa forma, comparando-os ao modelo mais difundido de família, que é aquele da família nuclear. A expressão "uma 
família como outra qualquer" está diretamente associada à noção de família constituída por um casal heterossexual e seus filhos biológicos.

Ao discutirmos as questões acima descritas, um dos entrevistados mencionou o nome de algumas mulheres que escrevem sobre terapia de família. A menção aos nomes das autoras fez com que o entrevistado comentasse sobre a prevalência de mulheres no campo da terapia familiar. Em suas palavras:

\footnotetext{
"Eu, como terapeuta masculino, noto que a terapia familiar está virando um matriarcado. Você vai a um congresso, têm $90 \%, 95 \%$ de mulheres e uns $5 \%$ de homens, no máximo. Eu sei o porquê disso ... De uns 20 anos para cá, ou talvez mais, as feministas viram que a terapia familiar era essencialmente o pensamento masculino, e elas gritaram. Começaram a sacudir aquilo tudo, e tinham razão em muitos itens. $\mathrm{O}$ que aconteceu é que elas foram para um outro extremo, e eliminaram o homem da terapia familiar" (TM.4).
}

As explicações do sujeito referem-se à critica feminista da terapia de família, movimento que ganhou força na década de 1980. A crítica feminista referia-se ao fato de que os arquitetos da terapia familiar, nos Estados Unidos, nas décadas de 1950 e 1960, eram todos homens brancos e oriundos da classe média, com exceção de Virginia Satir, uma das pioneiras do campo. As teorias por eles desenvolvidas em relação à estrutura familiar, refletiam suas posições em relação às questões de gêneros, e suas limitações. Segundo Elkaïm (1995), para os pioneiros, as famílias eram definidas segundo a presença de um casal heterossexual e sua prole, e outras configurações familiares eram vistas como patológicas ou tornavam-se invisíveis aos seus olhos. O autor comenta sobre a posição privilegiada da família nuclear na literatura ligada à terapia de família e observa que o paradigma feminista aponta para a diversidade de maneiras pelas quais os seres humanos podem ajustar-se intimamente em relação aos outros. Comenta, também, que menos de um terço dos lares norte-americanos são formados pela configuração familiar denominada de "normal". É interessante, portanto, refletirmos sobre o comentário de TM.4 acerca da "eliminação do homem da terapia familiar". Embora este seja um tema que pareça estar afastado dos objetivos imediatos do presente estudo, é importante lembrar que a crítica feminista à terapia de família foi um dos movimentos que deu início ao desenvolvimento de visões e abordagens mais inclusivas no campo das terapias. Foi a partir dos movimentos que questionaram os modelos de família "a serem 
alcançados", que os membros das diversas configurações familiares puderam sentir-se socialmente e terapeuticamente mais incluídos. Devemos lembrar que as famílias formadas pelo recasamento fazem parte desse grupo. 


\section{5}

\section{Considerações Finais}

Nossa proposta, ao longo deste estudo, foi analisar a percepção dos terapeutas de família do Rio de Janeiro a respeito do recasamento, assim como as possíveis transformações ocorridas na prática clínica, a partir do atendimento aos membros desta configuração familiar. Foi nosso objetivo verificar, também, as abordagens teórico-práticas preferencialmente utilizadas no atendimento às famílias recasadas.

A revisão da literatura sobre recasamento enfatiza a posição ocupada pela família nuclear, vista como modelo paradigmático ao qual as famílias recasadas são comparadas. Esta comparação, que ocorre tanto socialmente quanto por parte de um número significativo de terapeutas e pesquisadores, coloca a família de recasamento em uma posição pouco privilegiada, e soma-se às possíveis dificuldades de interação entre seus membros. Considerando a influência do modelo de família nuclear, determinante na formulação inicial de algumas abordagens de terapia de família, era nosso objetivo verificar, também, a abrangência dessa influência na prática clínica dos terapeutas entrevistados.

Foi possível perceber, através das respostas da maioria de nossos entrevistados, a influência significativa do modelo de família nuclear em suas formulações sobre as relações familiares no recasamento, assim como sobre as abordagens teórico-práticas utilizadas. É importante ressaltar que as críticas expressas pelos pesquisadores sobre a influência do modelo de família nuclear no atendimento a outras configurações familiares não sugerem um abandono completo do modelo. Este esteve e está presente em nossa sociedade. Sugerem, entretanto, uma análise mais ampla a respeito da ideologia a ele atrelada. Em outras palavras, as pesquisas atuais sobre família e terapia de família mostram que a família nuclear é uma das possibilidades de configuração familiar. Sem dúvida, é a possibilidade mais reconhecida e idealizada, a partir da qual as políticas públicas, referentes a famílias, da maioria dos países são elaboradas. Devemos considerar, no entanto, que com o desenvolvimento de pesquisas sobre o tema, 
atitudes mais inclusivas, relacionadas às diferentes configurações familiares, podem ser adotadas social e institucionalmente. A revisão da literatura internacional sobre o tema informa sobre a participação de terapeutas de família no desenvolvimento de pesquisas relevantes a respeito das transformações relacionadas às configurações familiares e da inclusão dessas novas famílias na sociedade.

Em relação às abordagens teórico-práticas preferencialmente utilizadas pelos entrevistados, evidenciou-se a prevalência da Terapia de Família Estrutural e das abordagens denominadas de pós-modernas, informadas pelo construtivismo e pelo construcionismo social. Como foi mencionado no Capítulo 3, a própria opção teórica do terapeuta aponta para a noção de um modelo de família. Percebemos que aqueles sujeitos que se referiram à Terapia Estrutural como orientação teórica preferencial, utilizaram, de forma explícita ou implícita, o modelo de família nuclear como parâmetro para a discussão sobre famílias recasadas. Os sujeitos que, também, explícita ou implicitamente, alinharam-se às outras abordagens acima mencionadas, apresentaram noções de família relativistas. Em suas definições, as relações familiares foram descritas de forma a contemplar aspectos como intencionalidade, autodenominação e auto-atribuição, o que aponta para a diversidade familiar descrita pela literatura de orientação pósmoderna.

A literatura por nós consultada faz uma articulação constante entre as pesquisas iniciais sobre o recasamento e as atuais, o que dá ao leitor uma noção de desenvolvimento e continuidade no estudo do tema. Além disso, as especificidades das interações entre membros de famílias recasadas são descritas de forma detalhada e as diversas perspectivas envolvidas, direta ou indiretamente na situação de recasamento, são abordadas. Constatamos, através do discurso da maioria de nossos entrevistados, um distanciamento em relação à leitura específica sobre o tema. Mais da metade dos sujeitos entrevistados pareceu não considerar relevante a necessidade de lançar mão de algum conhecimento específico no atendimento a membros de famílias recasadas. Alguns esclareceram que a orientação sistêmica por eles seguida adequava-se aos diferentes sistemas familiares que atendiam. Outros tornaram relativas as diferenças entre as diversas configurações familiares comentando que a família recasada era "uma família como outra qualquer”. Expressão também utilizada em relação às famílias 
homossexuais, uni-parentais e adotivas. Comentários semelhantes apareceram ao longo das entrevistas, apontando para uma contradição entre a relativização de um modelo de família que atenda à realidade daqueles que buscam ajuda psicoterápica, e o conceito de família do terapeuta.

Como mencionamos no Capítulo 4, as respostas de alguns dos entrevistados, em relação à situação de recasamento, pareceram apoiar-se muito mais na experiência clínica com famílias de primeiro casamento e em premissas do senso comum, do que em discussões e estudos específicos relacionados ao tema

A articulação entre a revisão da literatura e a pesquisa de campo nos possibilitou uma série de reflexões acerca de questões outras, que não aquelas diretamente relacionadas à clínica do recasamento. Embora essas questões possam ser mais amplamente elaboradas em outro trabalho, gostaríamos de registrá-las aqui. Entendemos que a mensuração acurada da ajuda psicoterápica é pouco facilitada pelo grau de subjetividade envolvido na natureza desta atividade. Nas formulações iniciais das abordagens de terapia de família, no entanto, a preocupação com resultados aparece de forma mais evidente. Na realidade, aquele que opta por fazer uma psicoterapia, pode sentir-se ajudado por atitudes que variam da escuta empática e acolhedora a uma postura mais diretiva por parte do terapeuta. Entre esses dois extremos existe um número de possibilidades terapêuticas que podem ser desenvolvidas. No caso de casais recasados, por exemplo, por estarem inseridos numa cultura onde a família nuclear aparece como um modelo a ser seguido, e por desconhecerem, freqüentemente, as especificidades envolvidas nas situações de recasamento, os membros do casal que buscam terapia, podem atribuir as dificuldades relacionais a eles próprios ou aos parceiro(as). Se o(a) terapeuta tem conhecimento da complexidade envolvida na adaptação dos membros da família recasada à nova vida, e dos caminhos que podem ser percorridos para contorná-la, ele(a) pode convidar o seu cliente a redesenhar o mapa do novo território familiar.

Não duvidamos das contribuições feitas pelos nossos entrevistados aos indivíduos que atendem. Percebemos, porém, que a maioria deles está inserida numa prática, que vai se modificando muito mais a partir das transformações sociais inevitáveis, do que a partir de possíveis reflexões sobre a articulação entre a teoria, a prática e as transformações sociais. Esta percepção nos aponta para 
mais uma reflexão surgida a partir deste estudo: a possibilidade de algum tipo de integração entre a graduação, em sua maioria de psicologia, que ocorre nas universidades, e a formação dos terapeutas de família, que geralmente é desenvolvida em outras instituições. Entendemos que este questionamento deverá ser analisado detalhadamente em outras pesquisas, mas como membros da comunidade acadêmica, da área de psicologia, temos a possibilidade de colocar em debate o distanciamento existente entre a teoria e a prática psicoterápica, assim como os possíveis atalhos para diminuir essa distância.

O interesse pelas questões relacionadas ao recasamento surgiu a partir de nossa prática clínica. Neste momento, podemos perceber que ao iniciarmos esse trabalho nosso objetivo restringia-se, essencialmente, ao tema. $\mathrm{O}$ acesso a pesquisas diversas, os debates com professores, colegas e terapeutas entrevistados, as incursões por outra áreas de saber desencadeadas pela revisão da literatura, acrescentaram muito mais à nossa prática clínica do que a princípio imaginávamos possível. Esperamos que esse estudo contribua para a compreensão da situação de recasamento e possa funcionar como um dos pontos de partida para outras pesquisas na área da prática clínica com as novas configurações familiares. 
6

\section{Referências Bibliográficas}

AHRONS, C. R. (1999) "Divorce: an unscheduled family transition". Em: Carter, B., McGoldrick, M. (org.) The expanded family life cycle: individual, family and social perspectives. Allyn \& Bacon, $3^{\text {rd }}$ edition, Boston.

ANDERSON, H. (1999) "Reimagining family therapy: Reflections on Minuchin's invisible family". Journal of Marital and Family Therapy. vol.25, n.1, p-1-8.

ANDERSON, H. e GOOLISHIAN, H. (1998) "O cliente é o especialista: a abordagem terapêutica do não saber'. Em: McNamee, S. e Gergen, K.J. A terapia como construção social. Artes Médicas, Porto Alegre.

ARIÈS, P. (1973) “ A história social da criança e da família”. Editora Guanabara, $2^{\mathrm{a}}$ ed. , Rio de Janeiro, 1981.

BATESON, G. (1979) “Mind and Nature”. E.P. Dutton, New York.

BERGER, P.L. \& KELLNER, H. (1964) "Marriage and the construction of reality", Diógenes, 46, p. 1-25.

BERNSTEIN, A.C. (1989) "Yours, mine and ours: how families change when remarried parents have a child together". Norton, New York.

BERNSTEIN. (1999) "Reconstructing the brothers Grimm: new tales for stepfamily life", Family Process, vol.38, n. 4, p.415-129.

BOSZORMENYI-NAGY, I. \& SPARKS, G.M. (1984) "Invisible loyalties". Brunner/Mazel, New York.

BOWEN, M. (1998) "De la familia al individuo: la diferenciación del sí mismo en el sistema familiar. Editorial Paidós.

BRAY, J.H., KELLY, J. (1998) “Stepfamilies”. Broadway Books, New York. 
BRITO, L.M.T. (1993) "Separando: um estudo sobre a atuação do psicólogo nas varas de família". Relume Dumará, $3^{a}$ ed., Rio de Janeiro.

BRUN, G. (1999) "Pais, filhos e cia. ilimitada". Editora Record, Rio de Janeiro.

BRUN, G. (1999) "Recasamento e linguagem", Cadernos IPUB/Instituto de Psiquiatria da UFRJ - n. 16, UFRJ, Rio de Janeiro.

CALIL,V.L.L. (1987) “Terapia familiar e de casal”. Summus, São Paulo.

CARTER, B., MCGOLDRICK, M. et al. (1989) "As mudanças no ciclo de vida familiar: uma estrutura para a terapia familiar". Artes Médicas, $2^{a}$ ed., Porto Alegre, 1995.

CARTER, B., MCGOLDRICK, M. et al. (1999) "The expanded family life cycle: individual, family, and social perspectives". Allyn \& Bacon, 3rd edition, Boston.

CERVENY, C.M.O., BERTHOUD, C.M.E. (1997) "Família e ciclo vital: nossa realidade em pesquisa". Casa do Psicólogo, São Paulo.

COLEMAN, M., GANONG, L. (1997) "How society views stepfamilies". Marriage and Family Review. vol.26, n.1-2, p.85.

COLEMAN,M., GANONG, L., FINE,M. (2000) "Reinvestigating remarriage: another decade of progress". Journal of Marriage and the Family, vol.62, n.4, p. 1289-1307.

COMBS, G., FREEDMAN, J. (1998) "Tellings and retellings". Journal of Marital and Family Therapy. vol.24, n.4, p.405-408.

COSTA, J. F. (1979) “Ordem Médica e Norma familiar”. 4ª ed. Graal, Rio de Janeiro.

DA MATTA, R. (1989) "A família como valor: considerações não familiares sobre a família brasileira". Em: Pensando a família no Brasil, Espaço e Tempo/ Ed. da UERJ, Rio de Janeiro.

DE'ATH, E. (1997) "Stepfamily policy from the perspective of a stepfamily organisation". Marriage and Family Review. vol.26, n.3-4, p.265. 
DELL, P. (1982) "Beyond homeostasis: Toward a concept of coherence". Family Process, vol. 21, n.1, p.21-41.

DELL, P. (1985) "Understanding Bateson and Maturana". "Journal of Marital and Family Therapy, vol.11, p.1-20.

ELION, D.A. (1990) "Therapy with remarriage families with children: positive interventions from the client perspective". Dissertação de Mestrado. Universidade de Wisconsin, Stout.

ELKAÏN, M. (1998) "Panorama das terapias familiares". vol. 1 e 2, Summus, São Paulo.

FÉRES-CARNEIRO,T. (1987) "Aliança e sexualidade no casamento e recasamento contemporâneo". Psicologia: Teoria e Pesquisa, vol.3, n.3, p. $250-261$.

FINE, M. (1997) "Stepfamilies from a policy perspective: guidance from the empirical literature". Marriage \& Family Review, vol. 26, n. 3-4, p. 249-262.

FURSTENBERG, F. F. (1987) "The new extended family: experience of parents and children after remarriage". Em: Pasley, K. \& IhingerTallman, M. (org.) Remarriage and stepparenting: current research and theory. Guilford, New York.

GAMACHE, S. (1997) "Confronting nuclear family bias in stepfamily research". Marriage and Family Review.vol.26, n. 1-2, p.41.

GERGEN, K. J. (1985) "The social constructionist movement in modern psychologist". American Psychologist, vol.40, p.266-275.

GERGEN, K. J. (1994) Realities and Relationships: Sounding in Social Construction. Cambridge, Massachusetts, Harvard University Press.

GERSON, G., MCGOLDRICK, M. (1985) "Genograms in family assessment". Norton, New York.

GENOVESE, Z.K.\& GENOVESE, T.A. (1997) "Developing spousal relationship within stepfamilies". Families in Society: The Journal of Contemporary Human Services. vol.78, n.3, p.255-263. 
GOODE, W. (1964) “The family", Prentice Hall Inc., New Jersey.

HAREVEN,T. (1991) "The history of the family and the complexity of social changes". The American Historical Review. vol. 96, fevereiro, p.95124.

HOFFMAN, L. (1994) "Fundamentos de la terapia familiar. Un marco conceptual para el cambio de sistemas". Fondo de Cultura Económica, México.

HOFFMAN, L. (1998) "Setting aside the model in family therapy". Journal of Marital and Family Therapy, vol.24, n.2, p.145-156.

HUGHES JR, R. e SCHROEDER, J. (1997) "Family life education programs for stepfamilies". Marriage \& Family Review, vol.26, n.3-4, p.281-295.

I.B.G.E. (1994) Pesquisa Nacional por Amostra de Domicílio.

JABLONSKI, B. (1991) "Até que a vida nos separe: a crise no casamento contemporâneo". Agir, Rio de Janeiro.

KEENEY, B.P., e SPRENKLE, D.H., (1982) "Ecosystemic epistemology: Critical implications for the aesthetics and pragmatics of family therapy". Family Process, vol.21, n.1, p.1-20.

KEENEY, B.P., (1983) Aesthetics of change. New York, Guilford Press.

KELLEY, P. (1996) "Family-centered practice with stepfamilies". Families in Society: The Journal of Contemporary Human Services. vol.77, n.9, p.535-543.

KERR, M., BOWEN, M. (1988) “Family evolution”. Norton New York.

LASCH, C. (1977) "Refúgio num mundo sem coração. A família: santuário ou instituição sitiada? “. Paz e Terra, Rio de Janeiro, 1991.

LEVIN, I. (1997) "Stepfamily as project ". Marriage and Family Review. vol.26, n.1-2, p.123.

LEVIN, I. (1997) "The stepparent role from a gender perspective". Marriage and Family Review. vol.26, n.1-2, p.177. 
MINUCHIN, S. (1990a) "Famílias: funcionamento e tratamento". Artes Médicas, Porto Alegre, 1990.

MINUCHIN, S.; FISHMAN, H.C. (1990b) "Técnicas de terapia familiar". Artes Médicas, Porto Alegre.

MINUCHIN, S. ; NICHOLS, M.P. (1995) "A cura da família". Artes Médicas, Porto Alegre.

MINUCHIN, S. (1998) Introdução. Em: Nichols, M.P. , Schwartz, R.C.

Terapia familiar: conceitos e métodos. Artmed, $3^{\mathrm{a}} \mathrm{ed}$, Porto Alegre.

MINUCHIN, S. (1998) "Where is the family in narrative family therapy?". Journal of Marital and Family Therapy. vol. 24, n.4, p.397-403.

MINUCHIN, S. (1999) "Retteling, reimagining, and re-searching: A continuing conversation". Journal of Marital and Family Therapy. vol.25, n.4, p.9-14.

MUMBY, D.K. (1993) Narrative and social control: Critical perspective. Newbery Park, Sage.

NICHOLS, M.P., SCHWARTZ, R.C. (1998) "Terapia familiar: conceitos e métodos". Artmed, $3^{\mathrm{a}}$ ed. Porto Alegre.

OSÓRIO, L.C. (1996) “Família hoje”. Artes Médicas, Porto Alegre.

PAPERO, D. (1998) "A teoria dos sistemas familiares em Bowen". Em: Elkaïn, M. (org.) Panorama das terapias familiares. Summus, São Paulo.

PASLEY, K. (1987) "Family boundary ambiguity: perceptions of adult stepfamily members". Em: Pasley, K. \& Ihinger-Tallman, M. (org.) Remarriage and stepparenting: current research and theory. Guilford, New York.

PONCIANO, E.L.T. (1999) "História da terapia de família: de Palo Alto ao Rio de Janeiro". Dissertação de Mestrado. Pontifícia Universidade Católica, Rio de Janeiro.

PONCIANO, E.L.T. (2002) "Família nuclear e terapia de família: conexões entre duas histórias". Estudos e Pesquisa em Psicologia. (no prelo). 
RAPIZO, R. (1998) "Terapia sistêmica de família: da instrução à construção". Instituto Noos, Rio de Janeiro.

ROCHA-COUTINHO, M.L. (1994) "Tecendo por trás dos panos: a mulher brasileira nas relações familiares". Rocco, Rio de Janeiro.

SAGER, C.J., WALKER,L., BROWN, H.S., RODSTEIN, E., CROHN, H. (1983) "Treating the remarried family". Brunner/Mazel, New York.

SARACENO, C. (1988) “Sociologia da família”. Editorial Estampa, Lisboa, 1997.

SEGALEN, M. (1996) “Sociologia da família”. Terramar, Lisboa, 1999.

SIMON, R.M. (1989) "Questões do ciclo de vida familiar no sistema de terapia". Em: Carter, B., McGoldrick, M. (Org) As mudanças no ciclo de vida familiar: uma estrutura para a terapia familiar. Artes Médicas, $2^{\mathrm{a}}$ ed., Porto Alegre, 1995.

SLUZKI, C. (1998) "In search of the lost family: A footnote to Minuchin's essay". Journal of Marital and Family Therapy. vol 24, n.4, p.415-417.

SMITH, D. (1993) "The standard north american family: SNAF as an ideological code". Journal of Family Issues. vol. 14, p.50-67.

TOMM, K. (1998) "A question of perspective". Journal of Marital and Family Therapy. vol. 24, n.4, p. 409-413.

TRAVIS, S. (1997) "Conflitos conjugais: um estudo sobre as expectativas no casamento". Dissertação de Mestrado. Pontifícia Universidade Católica, Rio de Janeiro.

TROST, J. (1997) "Step-family variations". Marriage and Family Review. vol.26, n.1-2, p. 71.

VAITSMAN, J. (1994) "Flexíveis e plurais: identidade, casamento e família em circunstâncias pós-modernas". Rocco, Rio de Janeiro.

VEIGA-DA-SILVA, C.E. (1997) "Partindo alianças, rompendo laços e seguindo em frente: um estudo sobre o processo de separação conjugal”. Dissertação de Mestrado. Pontifícia Universidade Católica, Rio de Janeiro. 
VISHER,E. \& VISHER, J. (1988) "Old loyalties, new ties". Brunner/Mazel, New York.

VISHER, J. (1994) "Stepfamilies: a work in progress". The American Journal of Family Therapy. vol. 22, n.4.

VISHER, E., VISHER, J., PASLEY, K., RHODEN, L. (1996) "Successful stepfamily therapy: clients' perspectives". Journal of Marital and Family Therapy. vol.22, n.3, p.343-357.

VISHER, E., VISHER, J., PASLEY, K. (1997). "Stepfamily therapy from the client's perspective". Marriage and Family Review. vol.12, n.1-2, p.191-207.

WAGNER, A., SARRIERA, J.C. (1999) "Características do relacionamento dos adolescentes em famílias originais e reconstituídas". Em: FéresCarneiro, T. (org.) Casal e família: entre a tradição e a transformação. Nau Editora, Rio de Janeiro.

WALKER, K.N., \& MESSINGER, L. (1979) "Remarriage after a divorce: dissolution and reconstitution of family boundaries". Family Process, vol.18, p.185-192.

WILLI, J. (1993) "A construção diádica da realidade". Em: Andolfi, M., Angelo, C., Saccu, C. (org.) O casal em crise. Summus, São Paulo, 1995.

WOODS, E.M.A.S. (1987) "Um estudo sobre o recasamento no Brasil". Dissertação de Mestrado. Pontifícia Universidade Católica, Rio de Janeiro.

ZONABEND, F. (1986) "Da família. Olhar etnológico sobre o parentesco e a família". Em: Burguièr, A., Klapisch-Zuber, C., Segalen, M., Zonabend, F. (org.) História da família: mundos longíquos. vol.1, Terramar, Lisboa, 1996. 